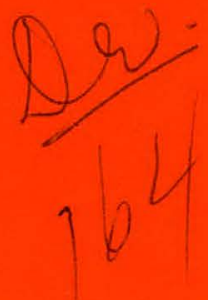

\title{
Utility Rates and Service Policies as Potential Barriers to the Market Penetration of Decentralized Solar Technologies
}

Randall J. Feuerstein
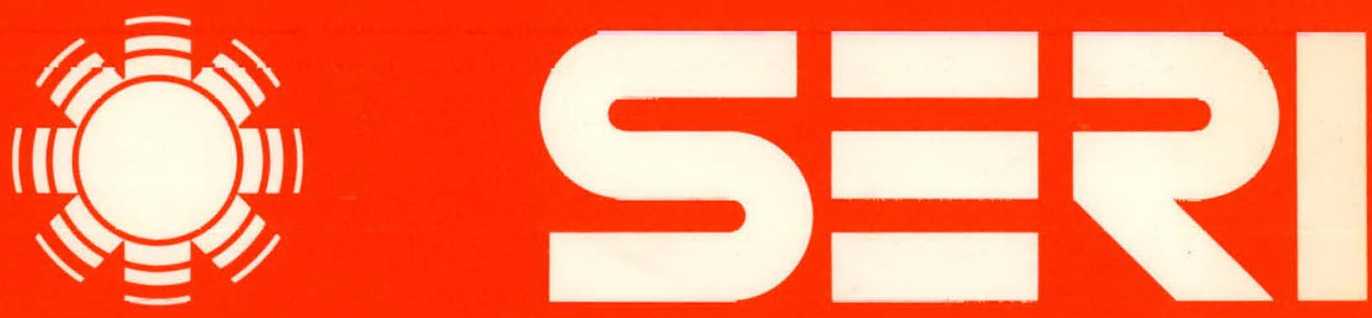

Solar Energy Research Institute A Division of Midwest Research Institute

1536 Cole Boulevard

Golden, Colorado 80401

Operated for the U.S. Department of Energy under Contract No. EG-77-C-01-4042 


\section{DISCLAIMER}

This report was prepared as an account of work sponsored by an agency of the United States Government. Neither the United States Government nor any agency Thereof, nor any of their employees, makes any warranty, express or implied, or assumes any legal liability or responsibility for the accuracy, completeness, or usefulness of any information, apparatus, product, or process disclosed, or represents that its use would not infringe privately owned rights. Reference herein to any specific commercial product, process, or service by trade name, trademark, manufacturer, or otherwise does not necessarily constitute or imply its endorsement, recommendation, or favoring by the United States Government or any agency thereof. The views and opinions of authors expressed herein do not necessarily state or reflect those of the United States Government or any agency thereof. 


\section{DISCLAIMER}

Portions of this document may be illegible in electronic image products. Images are produced from the best available original document. 


\author{
Printed in the United States of America \\ Available from: \\ National Technical Information Service \\ U.S. Department of Commerce \\ 5285 Port Royal Road \\ Springfield, VA 22161 \\ Price: \\ Microfiche $\$ 3.00$ \\ Printed Copy $\$ 7.25$
}

\title{
NOTICE
}

This report was prepared as an account of work sponsored by the United States Government. Neither the United States nor the United States Department of Energy, nor any of their employees, nor any of their contractors, subcontractors, or their employees, makes any warranty, express or implied, or assumes any legal liability or responsibility for the accuracy, completeness or usefulness of any information, apparatus, product or process disclosed, or represents that its use would not infringe privately owned rights. 
SER I /TR-62-274

UC CATEGORY: UC-59

UTILITY RATES AND SERVICE POLICIES AS POTENTIAL BARRIERS TO THE MARKET PENETRATION OF DECENTRALIZED

SOLAR TECHNOLOGIES

PANDALL J. FEUERSTEIN

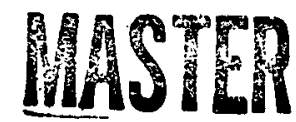

AUGUST 1979

\section{Solar Energy Research Institute}

1536 Cole Boulevard

Golden, Colorado 80401

A Division of Midwest Research Institute

Prepared for the

U.S. Department of Energy

Contract No. EG. $77 \cdot \mathrm{C} \cdot 01 \cdot 4042$ 
THIS PAGE

\section{WAS INTENTIONALLY LEFT BLANK}




\section{FOREWORD}

This paper on utility rates and service policies as potential barriers to the market penetration of decentralized solar technologies was prepared by the Solar Energy Research Institute (SERI) to fulfill, in part, SERI's solar information dissemination function. The paper is part of the Market Development Branch Law Program, which in turn is part of the overall program of the Technology Commercialization Division.

This is the eighth of eight 1978 Summar Law Intern Papers sponsored by the SERI Law Program. The other seven address (1) the impact of the antitrust laws on the commercialization of solar heating and cooling, (2) licensing arrangements and the development of the solar energy industry, (3) problems in the administration of state solar legislation, (4) legal and institutional implications of providing financial incentives to encourage the development of solar energy technologies, (5) legal considerations in the development and implementation of biomass energy technologies, (6) state approaches to solar energy incentives, and (7) land-use barriers and incentives to the use of solar energy. These eight studies are meant to raise and discuss the primary legal issues that are, or will be, generated by the commercialization of solar technologies.

The author of this paper, Randall Feuerstein, was a student of the University of Denver Law School while he was participating in the 1978 Summer Law Intern program. Much of this paper has previously been published as an article in the Solar Law Reporter [2 Solar L. R. 305 (1979)].

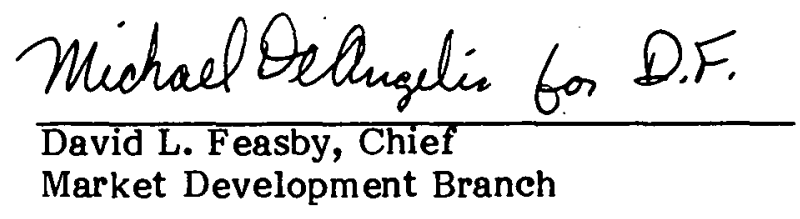

Approved for:

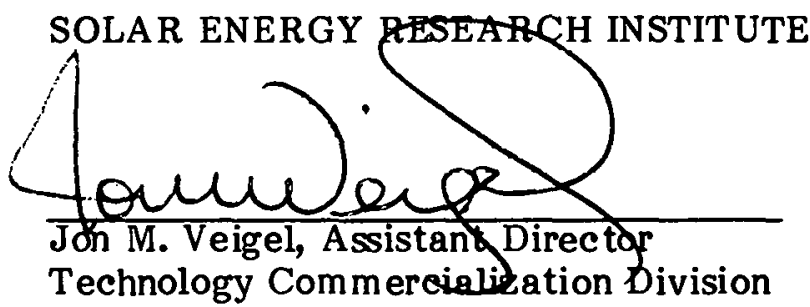


THIS PAGE

\section{WAS INTENTIONALLY LEFT BLANK}




\section{SUMMARY}

At present, economic and institutional concerns dictate that decentralized solar technologies generally require an auxiliary energy source to assure continuous service through periods of adverse weather. Utility rates and service policies regarding auxiliary energy service have a significant impact upon solar system economics, and thus the commercialization of solar energy. The scope of this paper evaluates three basic issues: (1) whether a utility can refuse to provide auxiliary service to solar users, (2) whether a utility can charge higher or lower than traditional rates for auxiliary service, and (3) whether a utility can refuse to purchase excess power generated by small power producers utilizing electricity-producing solar technologies.

Rate and service policies of investor-owned utilities are subject to regulation by constitutionally or statutorily created state agencies generally called Public Utilities Commissions (PUCs). Most states have public utility laws governing PUC jurisdiction and the extent of rate and service regulation.

In general, statutes or case decisions provide that a utility is under a primary duty to provide just, reasonable, and adequate service to all potential customers within its service territory. The duty to serve is not absolute, but is qualified by the intervention of circumstances not within the utility's control including: (1) customer misuse of service, (2) acts of God, (3) labor controversies, (4) shortage of supply, and (5) in some cases, lack of financial resources. It appears that a utility cannot refuse to provide auxiliary service to a solar user unless the above conditions prevail or the company can demonstrate that to provide such service, substantial harm would result to its existing customers.

Statutes or case decisions also provide that utilities cannot unreasonably discriminate in rates charged to customers for the same service under like conditions. Differences in rates between similarly situated customers are valid only where there exists a reasonable basis for distinguishing them. Reasonable bases include differences in: (1) the cost of service, (2) the quantity of energy used, (3) the duration of use, (4) the time when used, and (5) other considerations such as load factor. Since solar users potentially can exhibit a low load factor, different costs to service, and variable demands, they can be classified separately from other customers. The validity of separate solar rates, whether higher:rr lower than corresponding nonsolar rates, will be governed to a great extent by cost of service.

The ability of a utility to provide solar users lower than traditional rates may depend upon the jurisdiction's view of promotional rates. Promotional allowances have been upheld where they were reasonably expected to provide ultimate benefits to all customers. Since the commercialization of solar energy ( 1 ) is consistent with national policy goals of energy conservation and environmental protection, and (2) can potentially reduce utility capacity expansion and fuel expenditures, promotional solar rates could benefit all the utility's customers from both economic and social standpoints. Discrimination in rates is also subject to attack under federal antitrust laws and the Constitution.

Illino is has expanded its antidiscrimination statute to provide that no utility shall consider the use of solar energy as a basis for charging higher rates for any service provided to a solar customer. Therefore, a solar user qualifies for the rate he would have otherwise have been charged in the absence of the solar system; e.g., solar users having electrical backup qualify for promotional all-electric rates. The statute is designed to 
promote the commercialization of solar energy in the near term as the statute ceases to have legal effect in 1982.

An economic analysis of three ratemaking practices, which prove to be discriminatory toward solar users, was conducted. These practices were once enacted but are now removed. A demand/energy electric rate was found to be discriminatory toward solar users whose peak demand did not coincide with that of the system. Under a declining block rate, a customer who converts from all-electric to solar with electric backup would save $35 \%$ on his annual electric bills. This savings is reduced to only $15 \%$ under the demand/energy rate. Under a traditional residential gas service rate, a customer who converted from gas to solar with gas backup would save $58 \%$ on his annual gas bill. However, if the solar user was required to be served under a gas standby service rate, his annual gas bill would be $19 \%$ higher than if solar energy was not utilized. In one city, solar users were barred from taking advantage of the utility's promotional all-electric rates, regardless of the auxiliary, and were further required to deposit $\$ 200$ in addition to the standard service deposit.

Solar rates promoting the commercialization of solar energy exist in nine states. Most solar rates provide the same promotional discount during part or all of the year afforded to all-electric customers. Other solar rates are designed for the purchase of only offpeak auxiliary and are therefore lower. Solar rates are also offered to customers who agree to have service to their backup systems controlled by the utility. Under this scheme, the utility will provide service during other than peak periods at reduced rates. A proposed modification to the demand/energy rate discussed previously results in an annual electric bill savings of either $44 \%$ or $54 \%$ for a solar user accepting only off-peak service compared to an all-electric customer.

Some PUCs have policies that encourage utilities to purchase excess power generated by alternative energy sources. In one state, $P U C$ intervention in a rate negotiation prevented a utility from refusing to purchase excess power from a windmill. In most jurisdictions, though, it is unsettled as to whether a utility can refuse to purchase excess power from an electricity-producing solar technology. Windmill rates are offered in a few states and allow for the sale of excess energy to the utility at a rate either equal to (1) the utility's average cost of fuel, or (2) the rate charged for auxiliary service.

The National Energy Act statute will impact upon ratemaking practices applied to decentralized solar technologies. PUCs are required to consider the applicability of time-of-day ('IOU) rates, seasonal rates, interruptible rates, and lifeline rates. The Federal Energy Regulatory Commission (FERC) is required to establish rules requiring utilities to purchase power from small power producers. These rules are to insure that rates do not discriminate against small power producers or other customers. The FERC is also required to prescribe rules exempting small power producers from regulatory statutes where necessary to carry out the purposes of the legislation.

It appears that the most appropriate rate structure for solar users is TOD pricing. Such a structure will (1) encourage shif ting peak consumption to off-peak, (2) more closely track costs of service, (3) not discriminate for or against solar users, and (4) result in solar system designs that are more compatible with utility systems. The major barrier to the implementation of TOD rates is the cost of TOD meters. Other rates potentially beneficial to solar users are interruptible, lifeline, and inverted rates. These rate structures tend to result in a greater proportional savings to solar users than under traditional declining block rates. 
The time appears ripe for legislation to eliminate rate discrimination against solar users. Promotional solar rates could conceivably be mandated as being consistent with energy conservation goals and potentially beneficial to all utility customers. Timely consideration and enactment of such legislation would promote the commercialization of solar energy. Where legislation is not enacted, PUCs should take the initiative by establishing policies to discourage discriminatory rate and service practices against decentralized solar technologies. If nothing is accomplished in these early stages, solar users will have to rely on existing antidiscrimination statutes, current PUC policies, and the progress of national rate reform. 
THIS PAGE

\section{WAS INTENTIONALLY LEFT BLANK}


$i$

\section{TABLE OF CONTENTS}

1.0 Introduction $\ldots \ldots \ldots \ldots \ldots \ldots \ldots \ldots \ldots \ldots \ldots \ldots \ldots \ldots \ldots \ldots \ldots \ldots \ldots \ldots$

2.0 Regulation of Electric Utility Rates $\ldots \ldots \ldots \ldots \ldots \ldots \ldots \ldots \ldots \ldots \ldots \ldots \ldots$

2.1 Significant Early Regulation Decisions $\ldots \ldots \ldots \ldots \ldots \ldots \ldots \ldots \ldots \ldots \ldots$

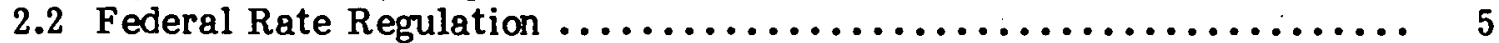

2.3 State Rate Regulation ............................. 6

2.4 Just and Reasonable as Standards of Rate Regulation ............ 8

3.0 Elootrio Utility Ratemaking $\ldots \ldots \ldots \ldots \ldots \ldots \ldots \ldots \ldots \ldots \ldots \ldots \ldots \ldots \ldots \ldots$

3.1 Rate Level Deter mination ......................... 11

3.1.1 Criteria of a Fair Return ......................... 11

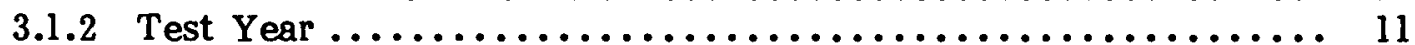

3.1.3 Operating Expenses............................. 12

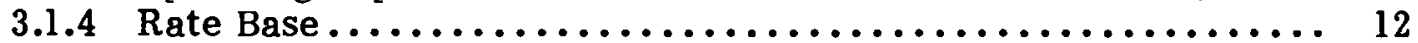

3.1.5 Rate of Return ............................. 13

3.2 Rate Structure For mulation $\ldots \ldots \ldots \ldots \ldots \ldots \ldots \ldots \ldots \ldots \ldots \ldots \ldots \ldots \ldots$

3.2.1 Rate Structure Criteria ........................... 14

3.2 .2 Electric Utility Characteristics .................... 14

3.2 .3 Electric Utility Costs ......................... 15

3.2.4 Non-Time-Differentiated Rates Based on Total Accounting Costs ......................... 16

3.2.5 Time-Differentiated Rates Based on Total Accounting Costs ......................... 17

3.2.6 Time-Differentiated Rates Based on Marginal Costs ......... 18

3.3 Rate Reform ................................... 19

3.4 Rate Structures $\ldots \ldots \ldots \ldots \ldots \ldots \ldots \ldots \ldots \ldots \ldots \ldots \ldots \ldots \ldots \ldots \ldots \ldots \ldots \ldots$

3.4.1 Declining Block Rates ......................... 19

3.4.2 Flat Rates ............................... 20

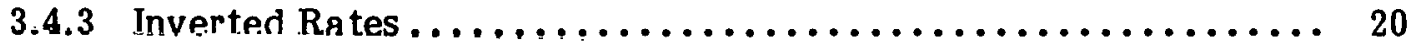

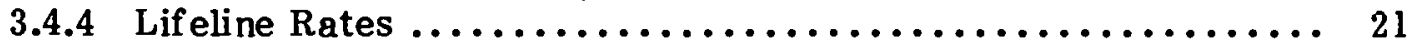

3.4.5 Demand Rates ............................... 22

3.4.6 Time-of-Use Rates ............................. 23

3.4.7 Interruptible Rates ........................ 27

4.0 Effect of Rates on Solar System Economics .................... 29

4.1 Demand/Energy Electric Rates...................... 29

4.2 Standby Service Gas Rates .......................... 32

4.3 Electric Service Advance Deposits....................... 33

4.4 Rate Structures and Solar System Design .................. 35

5.0 Impact of Solar Systems on Electric Utilities.................. 39

5.1 Federally Funded Studies ........................... 39

5.2 Electric Power Research Institute (EPRI) Studies ............... 45 
TABLE OF CONTENTS (concluded)

$\underline{\text { Page }}$

6.0 Electric Rate and Service Discrimination $\ldots \ldots \ldots \ldots \ldots \ldots \ldots \ldots \ldots$

6.1 Rate Discrimination .......................... 47

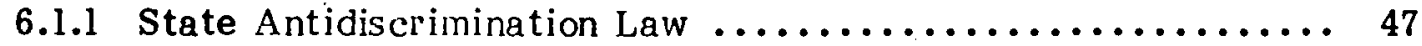

6.1.2 Federal Antidiscrimination Law .................. 50

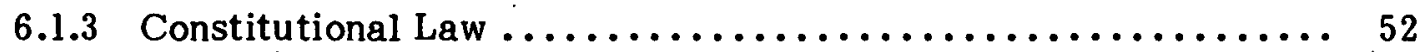

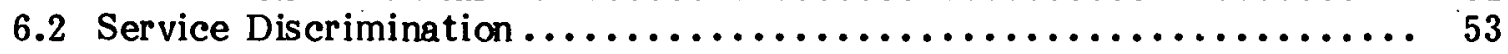

7.0 Existing and Proposed Solar and Wind Rates................. 55

7.1 Solar Rates.................................... 55

7.2 The Colorado Controversy Revisited..................... 58

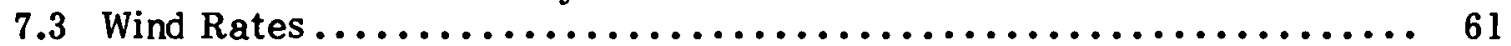

8.0 The National Energy Act and Electric Uttility Ratemaking $\ldots \ldots \ldots \ldots \ldots$

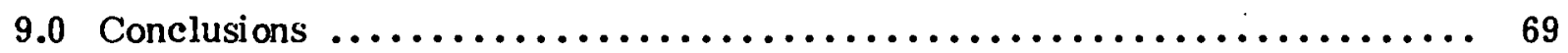

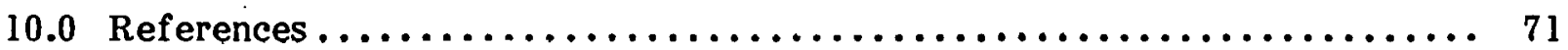




\section{LIST OF TABLES}

$\underline{\text { Page }}$

4-1 Comparison of Heat and Electrical Power Requirements for 10,000 Btu/Degree Day All-Electric and $70 \%$ Solar-Heated Homes in Denver Based on 1974 Weather Data ............................. 31

4-2 Comparison of Electric Utility Bills for 10,000 Btu/Degree Day All-Elec tric and 70\% Solar-Heated Homes in Denver . . . . . . . . . . . 30

4-3 Comparison of Heat and Natural Gas Requirements for 10,000 Btu/Degree Day Gas-Heated and 70\% Solar-Heated Homes Based on 1974 Denver Weather Data

4-4 Comparison of Gas Utility Bills for 10,000/Btu/Degree Day Gas-Heated and $70 \%$ Solar-Heated Homes

4-5 Comparison of Utility Bills for Electric-Heated and 70\% Solar-Heated Homes Based on Columbia, Missouri, Electric Service Rates........... 35

5-1 The Fractional Difference Between the Utility Costs [ $\phi / \mathrm{kWh}$ Required to Provide Backup Power to the Systems Shown and the Costs to Provide Power to a Residence Equipped with an Electric Heat Pump.......... 40

5-2 The Impact of Off-Peak Storage on Utility Costs $\ldots \ldots \ldots \ldots \ldots \ldots \ldots \ldots$

5-3 Ratio of Solar Demand to Conventional Demand at Peak............ 44

7-1 Electrical Power Requirements for an All-Electric Home and a 70\% Snlar-Heated Home in Denver and Comparison of Electrical Utility Bills for All-Electric and 70\% Solar-Heated Homes Based on HSCO's Proposed Residential Solar Service Rate...................... 


\section{SECTION 1.0}

\section{INTRODUCTION}

National concern over the steady depletion of our nonrenewable energy resources such as natural gas, oil, and coal, has lead to increased interest in alternative energy forms, including solar energy. This interest has also been stimulated by the increasing costs of fossil fuels, environmental problems with high-sulphur fuels, safety and environmental aspects of nuclear energy, increasing interest in energy conservation, and a push for energy independence. Solar energy did not appear economically attractive until the 1973 Arab oil embargo [1]. The successful OPEC cartel pointed out that reliance on foreign energy resource imports could prove hazardous [2].

Approximately $25 \%$ of the national total energy consumption is used for space heating, water heating, and air conditioning [3]. Decentralized or on-site solar technologies are best suited to serve commercial and residential heating and cooling needs [4]. The Office of Technology Assessment has found that (1) on-site solar hot water systems are economically competitive with electric hot water systems in most parts of the United States today; (2) solar space heating is, or soon should be, marginally competitive with heat pump and electric resistance heating systems in many areas of the United States; and (3) solar water heating and space heating systems may be competitive with oil or gas fired applications by the mid-1980s [5]. In addition, solar energy (1) draws on an inexhaustible source of energy, (2) is widely available, (3) does not produce significant environmental problems, and (4) will reduce fossil fuel consumption [6] .

One drawback to the use of decentralized solar technologies is that they require an auxiliary energy source to assure continuous service when, because of weather conditions, the solar devices are unable to function [7]. Some technologies use a form of energy storage, particularly thermal (liquid or air) or electrical (batteries). Should the thermal or electrical storage capacity be depleted during periods of extended cloudy weather, extreme cold temperatures, or insufficient wind velocity, a conventionally fueled auxiliary system would be required [8]. Typical energy sources for auxiliary systems include electricity [9] (heat pump and resistance heating applications), natural gas, propane, and fuel oil [10]. Optimally designed solar thermal systems generally provide $50 \%$ to $80 \%$ of a building's annual space conditioning and water heating needs [11]. The balance must be obtained from some form of backup system. The economic appeal of solar thermal systems is limited by expensive components-particularly the collector and heat storage areas governing the capacity of an auxiliary system.

In addition, other factors may require auxiliary systems in solar-equipped facilities. Legislation supporting solar use has generally required that the system comply with design and performance standards [12]. Where the system fails to comply, the owner of the solar system does not qualify for the legislative benefits. Such legislation could be drafted to require a conventionally fueled auxiliary system. Building codes may also require that a solar-equipped facility include a conventional auxiliary [13]. In addition, a financial institution in Colorado will not authorize a mortgage loan on a new residence utilizing solar energy unless the residence also contains an electric or propane auxiliary capable of providing $100 \%$ of the building's heating needs [14].

Utility company involvement in solar development includes providing conventional energy to auxiliary systems in solar-equipped buildings [15]. The cost of this auxiliary energy 
significantly affects whether the particular solar application is economically feasible [16]. In an investigation conducted for the Department of Housing and Urban Development (HUD), both utilities supplying auxiliary energy (gas or electricity) to HUD solar demonstration grant homes and utilities not supplying auxiliary services to HUD solar homes but possibly to other solar buildings, were interviewed [17]. Ninety-one percent of the utilities provided auxiliary service at standard rates, which neither encourage nor discourage the use of solar energy for residential purposes [18]. Sixty-seven percent of the utilities expressed concern that the widespread use of solar energy would increase peak loads while decreasing total revenues [19]. Many utilities are considering special rate structures for solar applications. The utilities were evenly split as to whether these special solar rates would result in higher, lower, or unchanged monthly bills for the consumer [20].

When utility service policies and rates for auxiliary energy are considered, the major concerns of the solar user are whether a utility (1) can charge higher rates for electric or gas service provided for backup; (2) must purchase excess energy from wind energy conversion systems or photovoltaic energy conversion systems and, if so, at what rate; and (3) can refuse to provide any service for auxiliary purposes.

'The balance of this paper will analyze these issues, discuss ratemaking in general, address the effects of decentralized solar market penetration on electric utilities, provide examples of existing and proposed solar rates, and discuss the National Energy Act as it applies to ratemaking and parallel generators. 


\section{SECTION 2.0}

\section{REGULATION OF ELECTRIC UTHITY RATES}

Before rate issues can be addressed, a fundamental understanding of utility regulation is needed [21]. Electric utility ratemaking [22] is subject to regulation [23] by the states under the police power [24], and by the Federal Government under the Commerce Clause of the United States Constitution [25]. There are four principle components of public utility regulation: price fixing, control of entry, prescription of quality and conditions of service, and imposition of an obligation to serve all applicants under reasonable conditions [26]. Rate regulation is the key consideration [27].

Rates are regulated primarily because electric utilities have traditionally been thought to be natural monopolies [28]. An electric utility, by virtue of practical considerations rather than legal restrictions, cannot operate efficiently unless it enjoys a monopoly of its market [29]. The theory is that it is better to have a few electric utilities that can provide better service rather than to permit many utilities to compete for business [30] because (1) monopolies eliminate costly duplication of facilities, (2) utilities realize decreasing average unit costs as output increases [31], (3) economies of scale are realized when utilities are able to utilize larger, more efficient facilities, (4) diversity of demand is usually higher when a utility serves an entire market rather than just a portion of that market [32], and (5) economies of scale are realized from purchases of large quantities of energy [33].

Rate regulation has been regarded as a substitute for competition [34]. Since customers of electricity cannot bargain for rates from the electric utility, price regulation is necessary to protect the public interest [35], by shielding customers from the potential excesses of monopoly pricing [36]. Price regulation also allows the electric utility a reasonable profit on its investment [37].

\subsection{SIGNIPICANT EARLY REGULATION DECISIONS}

Utility regulation, as it is known in the United States today, received judicial recognition in Munn v. Illinois [38]. This well-known and widely cited case established the principle that when property is used in a manner to affect the community at large, the owner must submit to being controlled by the public for the common good [39]. Because the case involved grain elevators whose operators fixed prices inconsistent with a state price regulation, the Supreme Court recognized the possible existence of a virtual monopoly [40], and thereby included the existence of a monopoly in the test for public interest status.

In 1933, the legislature of New York established a Milk Control Board with the power to fix maximum and minimum retail prices at which milk could be sold to consumers. The statute was challenged as a violation of the fourteenth amendment or an invalid exercise of the state's police power in Nebbia v. New York [41]. It was argued that the public control of rates was unconstitutional except where a business was affected with a public interest, and that a business so affected is commonly called a public utility. Justice Reynolds, speaking for the majority, stated:

We may as well say at once that the dairy industry is not, in the accepted sense of the phrase, a public utility. . . . 
[However]. . . 'affected with the public interest' is the equivalent of 'subject to the exercise of the police power;' and it is plain that nothing more was intended by the expression. . . .

It is clear that there is no closed class or category of business affected with a public interest, and the function of courts in the application of the Fifth and Fourteenth Amendments is to determine in each case whether circumstances vindicate the challenged regulation as a reasnnahle exertion of governmental authority. . . . The phrase 'affected with a public interest' can, in the nature of things, mean no more than that an industry, for adequate reason, is subject to control for the public gond. [4?]

The court held that the fifth and fourteenth amendments do not prohibit governmental regulation for the public welfare, but merely condition the exercise of this power by the limits of due process. A state may regulate a business in any of its aspects, including the prices to be charged for the products it sells [43].

In 1898, a Nebraska statute which reduced maximum railroad freight rates, was challenged in Smyth v. Ames [44] as constituting a denial of property without due process of law. The Supreme Court decision established the following principles: (1) a railraod corporation is a person within the meaning of the fourteenth amendment and is thereby entitled to due process of law; (2) state rate regulations that do not afford a railroad the opportunity to earn fair compensation deprive the railroad of property without due process of law; and (3) while rate determination is primarily a task for the state legislature, the decision of the legislature is subject to judicial review [45]. More significantly, the basis for all calculations must be the fair value of the railroan property used for the public convenience. This value is the original cost of the property, the present costs of construction, and the market value of bonds and stock [46]. The fair value concept, a compromise between original cost and reproduction cost new, continues to be used today by a minority of state commissions in their determination of rate base [47].

The decision in Los Angeles Gas and Electric Co. v. Railroad Commission [48] indicated the Court's refusal to be bound by a set formula when evaluating the reasonableness of rates. This trend culminated in a series of natural gas company cases of the early 1940s that departed from Smyth v. Ames. The Seventh Circuit, in Natural Gas Pipeline Co. v. FPC [49], vacated a commission order involving a $\$ 3.75$ million rate reduction of the annual revenues of two pipeline companies. Reversing the lower court and sustaining the commission's order, the Supreme Court stated that the constitution does not require ratemaking bodies to adhere to a particular formula or combination of formulas [50]. Agencies to whom the legislative ratemaking power is delegated are free to make pragmatic adjustments as required by particular circumstances. Once a commission hearing satisfying proper statutory standards has been held, courts cannot intervene without a clear indication that due process has been violated [51]. The Court further held that the lowest reasonable rates are those which are not confiscatory in the constitutional sense [52].

In FPC v. Hope Natural Gas Co. [53], the Supreme Court held that, under the just and reasonable statutory standard, not the method employed in establishing rates, but rather 
the end result is controlling [54]. The Court further stated that an order of the Federal Power Commission (FPC) is the product of expert judgment, which carries a presumption of validity. Therefore, one desiring to vacate such an order must make a convincing showing that it is unjust and unreasonable in its consequences [55]. From an investor's standpoint, it is important that rates generate enough revenue for operating expenses and capital costs, which include service on the debt and dividends on stock. Return on equity should be sufficient to assure confidence in the financial position of the company so as to maintain credit and attract capital [56]. Where rates are sufficient for successful operation, maintaining financial integrity, attracting necessary capital, and providing a fair return on investment, they cannot be deemed invalid even though they might produce only a meager return on the fair value rate base [57].

The original cost or prudent investment concept of rate base determination was introduced by Justice Brandeis in his dissent from the opinion Missouri ex rel. Southwestern Bell Telephone Co. v. Public Service Commission, [58]. He stated in his opinion that it is essential that the rate base be stable, definite, and readily ascertainable, and that it be established by the cost of capital employed by the enterprise [59]. Federal and state commissions viewed the concepts stressed by Justice Brandeis in Southwestern Bell and provided in Hope National Gas, as a less complicated determination of rate base than fair value. Today, a majority of jurisdictions rely on the original cost concept or a variation thereof [60].

\subsection{FEDERAL RATE REGULATION}

The Department of Energy Organization Act [61] established the Federal Energy Regulatory Commission (FERC) [62] and transferred FPC duties dealing with electric utility rate regulation to the FERC [63].

Portions of the Federal Power Act directly apply to electric utility rate regulation [64] Application of federal electric utility rate regulation is limited to the transmission of electric energy in interstate commerce, and to the sale of electric energy at wholesale in interstate commerce [65]. As defined within the Act, electric energy is transmitted in interstate commerce if transmitted from a state and consumed at any point outside that state [66]. A sale of electric energy at wholesale means a sale of electric energy to any person for resale [67]. A limitation on jurisdiction is provided, however, for facilities used for generation, local distribution, intrastate transmission, and transmission of electric energy consumed by the transmitter. Such facilities are generally exempt from FERC jur isdiction [68]. This exemption does not necessarily apply only to facilities used for the intrastate transmission of electricity. The test is whether the facilities are for local distribution [69]. However, where a company is in fact a public utility, all wholesale sales for resale in interstate commerce may be subject to FPC jurisdiction [70]

A solar user operating a wind or photovoltaic energy conversion system designed to generate electric energy to a utility for resale, or the utility that purchased this solargenerated electric energy, might face FERC regulation. To escape regulation, the solar power producer may seek the generation facility exemption or avoid public utility status because there has been no dedication of his facilities for the public convenience. The electric utility, on the other hand, would be required to show that the electric energy purchased from the solar small power producer remains in intrastate transmission or is confined to facilities used for local distribution. The Public Utility Regulatory Policies Act of 1978, one act comprising the popularly named National Energy Act, requires FERC to exempt small power producers, including wind and photovoltaic energy 
conversion systems, from jurisdiction of the Federal Power Act if the Secretary of Energy determines that such an exemption is necessary to implement the purposes of the Act [71]. The solar small power producer may wish to seek such an exemption.

The Federal Power Act further provides that rates and charges received by a public utility for the transmission or sale of electric energy and all rules pertaining to such rates and charges shall be just and reasonable, or be deemed unlawful [72]. What is just and reasonable is determined by the adequacy of public service, the fairness of the return on investment in the utility, and efficient use of the nation's power resources [73]. The Federal Power Act also mandates that no public utility shall, in any sale subject to FPC jurisdiction, (1) grant any undue preference or advantage to any person or subject any person to undue prejudice or disadvantage, or (2) maintain any unreasonable difference in rates between localities or classes of service [74]. Differences in rates have been held justified where they are predicated upon differences in facts such as costs of service. Where a difference in rates is challenged as discriminatory, judicial review centers on factual differences to justify classification of rates [75]. In FPC v. Conway Corp. [76], the Supreme Court held that the FPC has jurisdiction to consider a claim of discrimination predicated on a comparison of wholesale rates within the commission's jurisdiction and retail rates not within its jurisdiction. The commission has no power, however, to order the restructuring of retail rates to remedy an alleged discrimination between wholesale and retail rates [77].

When the FPC, after a hearing, finds that a rate is unreasonable, unduly discriminatory, or preferential, it is authorized to determine a just and reasonable rate [78]. Within the hearing, the FPC may consider the reasonableness of a classification treating different classes separately on the basis of timing of peak load, when the utility's rate structure does not set demand and energy charges by the time of customer's load [79]. Upon the filing of initial rate schedules, a public utility is required to submit to the FPC a summary statement of all cost computations whether fully distributed, incremental, or other [80], used in determining the rate with sufficient detail to justify the rate [81]. The public utility is also required to submit a detailed explanation of the methods used in arriving at the allocation [82] of cost-of-service for which the rate is proposed [83].

While the FERC may not be involved with ratemaking for nonpower-producing solar users, the significant body of case law that has developed concerning FPC rate discrimination issues certainly provides insight to resolution of similar issues at the state level.

\subsection{STATE RATE REGULATION}

Under their police power [84], states have the authority to regulate public utilities, including the authority to prescribe reasonable rates to be charged by public utilities [85]. Where rate regulation authority has been granted by the state constitution, it is subject to state constitutional limitations [86] in addition to the due process requirements of the fourteenth amendment to the United States Constitution [87]. The power to regulate rates can be exercised directly by the legislature [88], by municipalities [89], or by commissions [90]. A municipality or commission has no authority to regulate rates in the absence of a delegation [91] including standards to be followed [92].

The ratemaking function is solely legislative [93]; it is therefore not within the power of a court to fix or prescribe rates to be charged by a utility [94]. Judicial power over ratemaking is limited to whether rates are just and reasonable, or in violation of state and federal constitutions [95]. 
State governmental agencies regulating public utilities have been established in all 50 states [96]. These agencies are generally referred to as Public Utilities Commissions (PUC), Public Service Commissions, Railroad Commissions, State Corporation Commissions, or Commerce Commissions [97]. In general, PUCs are composed of from one to seven commissioners [98]. In a majority of the states, PUC commissioners are appointed rather than elected [99], thus freeing them from the burden of campaigning [100]. PUCs have electric rate regulation authority in all states but Nebraska [10l], where there are no private investor-owned electric utilities within the state [102], and the retail rates of publicly owned electric utilities within the state are municipally regulated [103] .

PUCs can be of constitutional [104] or statutory [105] origin. State statutes expand the regulatory authority of the PUCs and provide guidelines. State statutory compilations are referred to as the Public Service Law [106] or the Public Utilities Law [107].

PUC jurisdiction to regulate electric rates is limited to matters of local distribution and does not extend to interstate sales of electric energy for resale [108]. Generally, a section within the states' public utilities law confers PUC regulatory jurisdiction over specified public utilites. For example, the New York commission has jurisdiction over the manufacture, sale, or distribution of gas and electricity for light, heat, or power [109]. In Wisconsin, the commission supervises every public utility in the state [110] including every company, association, individual, town, village, or city that owns or operates any equipment for the production, transmission, or furnishing of heat, light, water, or power to the public [111]. In Colorado, a public utility includes every common carrier, pipeline corporation, gas corporation, water corporation, person, or municipality operating for the purpose of supplying the public, or every corporation or person declared by law to be affected with a public interest [112].

PUC regulatory jur isdiction over municipal utilities and cooperatives varies from state to state [113]. For example, the $\mathrm{New}$ York and Wisconsin commissions receive their authority to regulate municipal electric utility rates and service by statute [114]. In Colorado, cooperative electric associations are declared to be affected with a public interest and are therefore subject to PUC regulation [115]. An exemption for municipally owned utilities from regulation of facilities, service, and rates, however, is provided in the Colorado constitution [116]. The Colorado Supreme Court has held that the PUC has no jurisdiction to regulate a municipally owned utility which operates wholly within the territorial boundaries of a home-rule city [117]. In a recent decision, however, the Colorado Supreme Court held that Colo. Const. art. V \$35, prohibiting the PUC from regulating utilities operated by a municipality within its boundaries, does not prohibit the PUC from regulating municipally owned public utilities to the extent of their operations outside city boundaries [118].

Public utility status and PUC jurisdiction are significant issues to the operator of wind or photovoltaic systems suppling electric energy to a utility. To the extent that a solar user is subject to licensing, franchises, site regulations, and certification for public convenience and necessity, such regulation acts as a disincentive for operation [119]. PUC rate regulation may be beneficial, however, to the small power producer because rates are required to be just and reasonable [120]. Furthermore, orders of the PUC may be required to compel electric utilities to purchase excess power from small power producers who qualify for interconnection. If the setting of sell-back rates were left to the parties, the small power producer would be at a bargaining disadvantage.

Portions of the states' public utility laws provide that the electric utility render safe, adequate service at just and reasonable rates without undue discrimination [121]. Under 
the New York Public Service Law, the reasonableness of a rate classification established by a public utility for electric service is an issue to be determined in the first instance by the state commission rather than by the courts, except where a question of law is involved [122]. Whenever the New York commission finds, after a hearing on its own motion or complaint, that rates charged by an electric corporation or municipality are unjust, unreasonable, unjustly discriminatory or unduly preferential, the commission shall determine and prescribe the just and reasonable rates [123].

In Wisconsin, every public utility is required to furnish reasonably adequate service and facilities, and the charge made therefor shall be reasonable and just [124]. Unreasonably low rates, according to the Supreme Court of Wisconsin, occur where such rates will yield less than the minimum return which invested capital has a right to demand [125]. Whenever the Wisconsin commission finds that rates are unjust, unreasonable, insufficient, or unjustly discriminatory, the commission has the authority to determine and by order fix reasonable, nonconfiscatory rates [126].

Colorado has similar statutory provisions: the Public Utilities Law requires that all charges made by a public utility for service rendered be just and reasonable [127], and that every public utility shall furnish service and facilities as shall promote the safety, health, and convenience of its patrons and the public and as shall be adequate, just, and reasonable [128]. The Colorado PUC is vested with the power and authority to adopt all necessary rates to correct abuses [129]. The U.S. District Court has stated that rate fixing by the PUC is largely a matter of prophecy, so the commission necessarily deals in zones of reasonableness, meaning that it has some latitude in fixing rates [130].

\subsection{JUST AND REASONABLE AS STANDARDS OF RATE REGULATION}

The issues of what are just and reasonable rates and service [131] have been the subject of much litigation. Rates prescribed must allow the public utility to receive just compensation for the service rendered to the public, but may not be exorbitant [132]. A commission may find reasonable a rate that produces revenues substantially higher than a fair return on the value of the property used to render the service [133]. In determining whether rates are confiscatory in the constitutional sense, it is necessary to consider the actual effect of the rates prescribed in light of the utilities' situation, requirements, and opportunities [134], and involves a balancing of consumer and investor interests [135]. Rates charged to other customers is evidence of reasonableness only when the conditions of service are similar [136].

The two most frequently cited criteria of reasonable rates are cost-of-service and valueof-service $[13 \%]$. The zone of reasonableness is governed by the value of service to the customer and the utility's cost of providing the service, including investor return [138]. The reasons offered to justify a cost-of-service based ratemaking standard are that (1) consumers should be free to enjoy the services they can pay for; (2) such a pricing scheme controls demand and motivates the utility to supply the service; and (3) the user should pay for what he uses [139]. Cost-of-service as a criteria for reasonableness in rate structure design has been widely recognized in court and PUC decisions. The Supreme Court of North Carolina held that the basic theory of ratemaking is that rates should be set at a level which will recover the cost-of-service plus a fair return to the utility [140]. The Supreme Court of Georgia stated that the determination of what is a just and reasonable rate involves a matter of policy, and is at best an approximation based on an estimate of present and probable future values [141]. Cost-of-service is one factor that is given consideration in the formulation of rates by the Nevada commission 
along with other factors, including, value-of-service [142], price elasticity [143], conservation, and historical rate practices [144]. The Iowa commission has held that cost of service is the fundamental standard and the almost universally accepted criteria for rate design [145]. Cost-of-service was held by the Kansas commission to be the generally accepted method of determining the reasonableness of rates and absence of undue discrimination [146]. A pure cost-of-service approach, however, was deemed unworkable by the Wyoming commission because (1) the expense of determining and administering costs for each individual customer would be too great, (2) it does not consider service class interdependency, and (3) service to residential customers would be prohibitive [147]. The commission further stated that proper rate design should include a compromise of relevant considerations in addition to cost-of-service, including the ability of customers to pay, types of customers, demand for service, and value of service.

Cost-of-service is a significant factor courts and commissions consider in determining whether rates are reasonable. Since the solar user is essentially a new type of customer to the electric utility, it follows that cost-of-service studies [148] should be conducted for various solar technologies [149]. It does not seem reasonable that solar users should be classified with other customers in the general residential sector or a more narrow category, such as all-electric customers, without studies justifying such a classification.

Because of the uncertainty and instability associated with the cost-of-service basis for price fixing [150], it has been argued that factors on the demand or customer side of the market should be recognized. The value-of-service concept [15l] takes into account the relative price elasticities of demand for services to various customers or customer groups [152]. The most prominent example of the use of value-of-service in rate structure design is the setting of railroad freight rates and ratemaking in the telephone industry [153]. Where cost-of-service analysis is relied upon and used extensively in the electric utility industry, it is likely that value-of-service princlples are secondary concerns if even considered at all. Bonbright provides three meanings for value of service in ascertaining reasonableness: (1) pricing to maximize public utility profits (the monopoly price), (2) price discrimination [154] based on various price elasticities of demand; c.g., recovering revenue deficiencies from the classes having lower price elasticities of demand when the use of out-of-pocket costs produces Insufficlent revenues, and (3) pricing at the market-clearing price; i.e., pricing just sufficient to secure full use of service as limited by plant capacity [155]. When the Supreme Court articulated the fair value rule of ratemaking as applied to rate bases in Smyth v. Ames, a qualification was added that a public utility may not exact from its customers charges higher than the services are reasonably worth [156]. The value-of-service concept was followed by the $W$ isconsin commission in a case involving the classification of gas heating customers from customers using gas for other uses. Separate classifications were justified by the difference in value of gas for space heating and gas for other purposes [157]. Since Smyth v. Ames, the Supreme Court has held that the value of service concept is a factor that should be considered in setting rates [158].

A solar user may be concerned with value-of-service concepts in the allocation of joint costs; i.e., costs associated with an indivisible production process that yields two or more services. It has been suggested that capacity or de mand costs [159] be allocated between customer classes on a value-of-service basis or by utilizing the various price elasticities of demand between service classifications [160]. Where the price elasticity of a solar user is signficantly different than that of other customers within his class, a further capacity cost. allocation within the class may be warranted.

It may be beneficial to the small power producer to have sell-back rates subject to PUC regulation to ensure that the rates would be just and reasonable. What a commission 
would consider to be a just and reasonable sell-back rate should depend upon the use the excess energy is scheduled to serve. Should the excess energy be used for distribution purposes, it appears that a just and reasonable sell-back rate would logically be the same auxiliary service rate charged to the small power producer by the utility. Such a sellback rate would account for the plant capacity costs (generation, transmission, and distribution) and energy costs displaced by the small power producer's excess energy. Another method of fixing a sell-back rate would be to follow guidelines for cogenerators as provided in the National Energy Act. In the Act, a ceiling is set on sell-back rates based on the utility's incremental cost of generating or producing energy in an amount equal to the excess energy purchased at the time of purchase. 
SECTION 3.0

\section{ELECTRIC UTILITY RATEMAKING}

In FPC v. Natural Gas Pipeline Co., Chief Justice Stone, speaking for the U.S. Supreme Court, stated:

The establishment of a rate for a regulated industry often involves two steps of different character, one of which may appropriately precede the other. The first is the adjustment of the general revenue level to the demands of a fair return. The second is the adjustment of a rate schedule conforming to that level so as to eliminate discriminations and unfairness from its details. [161]

Taking the elements of ratemaking in the order suggested by Justice Stone, step one involves the ascertainment of the electric utility's annual revenue requirements while step two is concerned with designing a rate structure to recover this revenue requirement.

\subsection{RATE-LEVEL DETERMINATION}

A controlling basis of rate regulation throughout the United States is the fair-return standard [162]. The usual meaning of fair return is the excess in operating revenues above current operating deductions that a PUC will include as a component in the utility's annual total revenue requirement [163]. PUCs generally ascertain what a utility's revenue requirement will be by (1) estimating the rate base, (2) determining the maximum allowable rate of retum on the rate base, (3) multiplying the rate of return and the rate base, and (4) adding to this product the annual operating expenses and taxes [164]. A utility's total cost-of-service can be equated with its revenue requirement, defined as the sum of operating expenses, depreciation expense, taxes, and a reasonable relurn on the rale base [165].

\subsubsection{Criteria of a Fair Return}

There are five criteria or principles by which to measure a fair return [166]. The first criterion, that there must be a sufficient return in order to attract needed capital, is probably the most important. The second criterion is that the return reward efficient utility management and discourage inefficiency. The Supreme Court of North Carolina recognized this principle when it held that, where a utility is found to be rendering inadequate service due to inefficient management, the state commission may lawfully deny a request to increase rates for such service [167]. The third criterion is rate level stability. Consumer-rationing is the fourth principle. There may be a conflict between this principle, involving value-of-service, and the capital-attracting criterion of cost-ofservice [168]. The fifth principle is fairness to investors. The first four principles could be classified as criteria designed in the interests of consumers, but the final criterion is reserved for investors and is indicated by the history of rate law to be almost as important as the others [169].

\subsubsection{Test Year}

Significant to the determination of a utility's revenue requirement is the selection of a test year or test period in which financial information on the utility's operations is 
available. The test year is used to acquire data on revenues, investment, and expenses [170]. Reasonable test years have been found to be the latest 12-month period for which actual data were available [171]. PUCs have also required that estimates for a future test period be submitted [172].

\subsubsection{Operating Expenses}

The ratio of a utility's annual operating expenses, including depreciation, taxes, and maintenance, to the utility's fair return (percentage rate of return times rate base) ranges from 3:1 to 10:1 or even higher [173]. Operating expenses [174] are the largest factor of a utility's annual revenue requirement. Labor, maintenance costs, materials and supplies, and various services are operating expenses [175]. Depreciation, tax, and amortization expenses are accounted for separately in the utility's accounts [176], but for the purpose of this discussion, will be treated as a portion of annual operating expenses. The need for regulatory review of utility practices regarding operating expenses was recognized by the Supreme Court in Chicago and Grand Trunk Rail way Co. v. Wellman, where it was held that a court should be advised of a company's operating revenues and expenses before a decision can be rendered on the constitutionality of a rate-fixing statute [177]. Expenses must be excluded if (1) they represent inefficiency, (2) managerial discretion has been abused, (3) the company's practice is inimical to the public interest, (4) there is evidence of economic waste, or (5) the expensed items are in excess of just and reasonable charges [178]. Decisions have been rendered which adiress the propriety of including taxes [179], advertising [180], salaries and wages [181], and maintenance and depreciation [182] as operating expenses.

\subsubsection{Rate Base}

Experts in the area of public utility regulation indicate that the measurement of rate base is the most frequently disputed legal issue in modern public utility law [183]. The rate base includes the actual cost of plant and equipment used for the public convenience, with reasonable allowances for working capital, less accumulated depreciation [184].

There are two basic methods employed by commissions today to value property used in providing the utility service: original cost and fair value. Under the original cost or net investment method, used by the FERC and the majority of states [185], the value of the investment rate base can be obtained from the utility's books [186]. Original cost was espoused by Justice Brandeis in his dissent from the opinion in Missouri ex rel. Southwestern Bell Telephone Co. v. Public Service Commission of Missouri [187], and recognized in F PC v. Hope Natural Gas Co. [188]. Original cost is the total original investment in constructed and acquired plant and equipment when devoted to the public use, less depreciation. Arkansas is an example of an original cost jurisdiction [189]. The Supreme Court of Arkansas stated in Acme Brick Co. v. Arkansas Public Service Commission, that the rate base within the jurisdiction is the prudent investment value of the property of the utility [190].

Under the fair value concept of rate base determination, as provided in Smyth v. Ames [191], depreciated actual cost and reproduction cost new, less accumulated depreciation, are considered [192]. The significant difference from the original cost concept is the use of reproduction cost new. Reproduction cost new is that cost required at the present moment to replace existing plant and equipment [193]. To arrive at fair value, that 
portion of the rate base allocated to actual cost can be obtained from the utility's books. The portion of the rate base valued by reproduction cost new will be applied to various price indicies giving expression to the value of existing plant and equipment in current dollars [194]. Arizona is one of the states using the fair-value valuation method [195]. The Arizona constitution requires that the state commission find the fair value of the utility's property [196], and use such finding for calculating just and reasonable rates [197]. The state's Supreme Court, in applying the fair value constitutional provision, said that determination of the fair value of the property was required by the constitution and that the "commission must establish the rate base on the basis of fair value and that alone" [198].

The New York public service law contains provisions using a value standard in one instance and an investment standard in another. The state commission is required to consider the value of the property used in the public service when fixing telephone and telegraph rates [199]. When the commission is involved with ratemaking for gas, electric, and water utilities, it is required to consider a reasonable average return on capital actually expended [200]. Other jurisdictions, such as New Jersey, are difficult to classify as either an original cost or a fair value jurisdiction [201].

\subsubsection{Rate of Return}

A final element in rate-level determination involves the ascertainment by regulatory commissions of a fair rate of return [202]. Rate of return is the percentage by which the rate base is multiplied in order to arrive at the fair return, or an amount sufficient to (1) cover annual interest on long-term debt, (2) pay dividends on preferred stock, and (3) provide a dividend on common stock or increase earned surplus [203]. The legal tests for a fair rate of return are summarized in Bluefield Waterworks and Improvement Co. v. Public Service Commission of West Virginia [204] and Hope Natural Gas Co. [205]. In Bluefield, Justice Butler stated that a public utility is entitled to rates as will permit it to earn $a$ return on the property used in the public service, generally equal to that being earned at the same time on investments in other enterprises attended by comparable risks (comparable risk test) [206]. In Hope Natural Gas, Justice Douglas said:

it is important that there be enough revenue not only for operating expenses but also for the capital costs of the business .... [includingl service on the debt and dividends on the stock .... [207]

The two basic methods for measuring a fair rate of retum are the cost-of-capital [208] and a retum similar to that earned by investments in comparable risk enterprises [209] . The cost-of-capital standard utilizes the composite weighted cost of debt, preferred stock, common stock, and earned surplus [210]. This standard is said to be consistent with fair return criteria of credit maintenance and attraction of necessary capital [211]. The comparable risk standard measures competition for funds in the capital market [212].

The two standards were affirmed but modified by the Supreme Court's later decision in Permian Basin Area Rate Cases [213], which reflected a concern by the Court that regulatory processes reflect the special circumstances of area regulation [214] and that the end result of the agency's orders should protect the public interest by the same degree that financial integrity is maintained [215]. 


\subsection{RATE STRUCTURE FORMULATION}

The revenue requirements of a utility are achieved by rate structures designed to allocate costs efficiently among the various customer classes. The legal tests applicable to rate structure design [216] are that rates shall be just and reasonable and that they shall not be unduly discriminatory [217]. Cost-of-service and value-of-service are fundamental concepts used in application of the reasonableness test. Because regulatory commissions have been generally more concerned with rate level determination than rate structure formulation, rate structure design has been left under the control of utility management [218]. With the nationwide push for rate reform [219], however, this trend has been changing.

\subsubsection{Rate Structure Criteria}

Bonbright provides a list of eight objectives that a sound or desirable rate structure should attain [220]. The three primary criteria are: (1) sufficient revenues to cover the revenue requirement, (2) distribution of the burden fairly among customers, and (3) a rate structure that discourages waste while promoting efficient use of utility services [221]. Although the value-of-service reasonableness test may be inconsistent with the second criterion, social considerations [222] and complexity of cost relationships justify some deviation from a strict cost-of-service concept of rate design [223]. The efficient use of utility services has been expressly recognized by both the New York and Wisconsin commissions. The New York commission has stated that traditionally based rates do not necessarily achieve economic efficiency, environmental protection, and conservation; consequently, rates designed to promote economic efficiency should be investigated and implemented if the goals mentioned previously will be achieved [224]. Similarly, the Wisconsin commission recognized the benefits and desirability of rates designed to promote an efficient allocation of resources [225].

\subsubsection{Eleetric Utility Characteristics}

Design and operation of an electric utility system depends upon the load patterns of the utility's customers. At some point during the year, the load on the utility's system is at its peak. Because electricity cannot be stored eronnmirally, the utility must maintain sufficient plant capacity to meet this annual peak load or peak demand when it occurs, plus additional capacity as operating reserve to satisfy regional reliability criteria [226]. Peak demand can be stated in terms of the time period within which it occurs; e.g., daily, monthly, or annually. Peaks occur either in the winter due to heating loads, or in the summer due to industrial and air conditioning loads.

Generating capacity is incorporated in the plant design in the form of base load, intermediate or cycling, and peaking units. The base load facilities, generally the largest (200-1,200 MW) and most efficient, are intended to operate steadily throughout the year except for periods of scheduled maintenance. As the daily load increases to near the capacity of the system's base load units, smaller sized, less efficient cycling units are added in anticipation of the increased demand. Finally, as the daily load approaches its peak, peaking units (i.e., $100 \mathrm{MW}$ gas-fired turbines), will be added incrementally to meet the total demand. If a system has ties with other areas, its generating capacity may be augmented by power from a neighboring system.

Load factor is the average use of facilities as a percentage of the maximum use; the ratio of average power to peak power [227]. A higher load factor results in lower 
average costs of service per unit of energy (kWh) [228] because average costs are inversely proportional to energy output. Diversity of demand must also be considered when the system's capacity requirement is being determined [229]. Diversity of demand is the ratio of the sum of the individual peak demands of all customers to the peak demand of the system. Customers having high-load factors, because of more constant use, are apt to have low diversities of demand. Conversely, customers having low-load factors are likely to have high diversity of demand because their nonuse may free capacity to serve the needs of other customers [230].

Utilities must spread the costs of their plant capacity, whether generating or lying inactive, and of their fuel, operation, and maintenance over the amount of energy sold. To minimize costs, utility managers try to maintain a high-load factor for their systems. The basic goal is to minimize the difference, subject to reserve capacity requirements, between the highest demand and the average demand on the system. The smaller the difference, the higher the load factor is and the more efficient the operation becomes, permitting higher profit for the utility and perhaps lower charges to its customers.

In addition to generating equipment, a typical electric utility system will contain transmission facilities designed to operate at high voltage for power transmission. Power is distributed to customers at lower voltage levels through distribution systems.

\subsubsection{Electric Utility Costs}

Other costs affect the utility's rates. Total accounting costs are the aggregate of all costs realized by the electric utility to produce a quantity of electric energy over a given period of time. These include all operating expenses, depreciation, taxes, and an allowance for return on investment (the revenue requirement) [231]. Average accounting costs are determined by dividing the total accounting costs for a given period by the number of $\mathrm{kWh}$ generated during that period.

Total accounting costs can be broken down further into fixed and variable costs. Fixed costs are those costs that do not vary with varying output [232]. Costs associated with generation, transmission, and distribution facilities will to a large extent be fixed. Variable costs, oln the ulher hand, vary with the level of output, such as fuel costs [233] and certain maintenance expenses [234].

Marginal cost is the cost to produce one more unit of output [235], or in this case, one more $\mathrm{kWh}$. Economists contend that, ideally, consumers ought to pay a price equal to the marginal cost of the product or service because prices should reflect opportunity costs, that is, the costs of sacrificing alternatives [236]. The pricing of all goods and services at their marginal cost results in optimum allocation of resources and economic efficiency.

Marginal costs depend to a great extent on the duration of the increased output; i.e., whether the additional output is to be continued for five minutes or five years. As a result, economists have defined short-run marginal costs (SRMC), as those due solely to increased use of existing plant capacity; long-run marginal costs (LRMC) are those requiring additions to existing plant capacity [237]. Short-run marginal costs of an electric utility vary depending upon the level of output [238]. The short-run marginal costs of an additional $\mathrm{kWh}$ during base load periods will be less than the cost during peak load periods, primarily because of fuel costs at peak. As loads vary hour by hour, so do 
the short-run marginal costs of providing service. It can be seen that these costs are volatile; one reason that regulators and economists do not advocate rates based on SRMC [239]. Long-run marginal costs reflect the costs of capacity needed to satisfy a sustained increment in the rate of output [240]. The short-run marginal costs of producing an additional $\mathrm{kWh}$ in a system with extra capacity will be relatively low, including only fuel and possibly operating and maintenance costs. In the long run, though, capacity wears out; capacity costs are treated as variable and are considered in the determination of long-run marginal costs. The stability of LRMC justifies the use of LRMC over SRMC in ratemaking applications [241].

Incremental costs are costs associated with adding large quantities of output [242]. In the electric utility industry, these costs are important because there is no meaningful measure of single unit cost. Unit cost of capacity additions $(\$ / \mathrm{kW})$ can then be derived by dividing the total incremental cost by the added capacity (kW').

\subsubsection{Non-Time-Differentiated Rates Based on Total Accounting Costs}

To design a rate structure based on total accounting costs requires a cost study of the utility's past operations. This is generally done by performing a cost study which analyzes past operations for a given period and assigns total accounting costs among the various classes of service [243]. Having ascertained the total accounting costs or revenue requirement, the next step is to distribute the costs among the major functions of generation, transmission, and distribution [244].

Next, these costs are classified into demand, energy, and customer groups. Demand or capacity costs are those that vary with the $\mathrm{kW}$ of demand imposed on the system by customers. Demand costs comprise the major portion of fixed investment in providing and maintaining the plant, including generation, transmission, and distribution facilities to meet the maximum demand on the utility's system. These costs include the cost of capital, taxes, depreciation, operation, and maintenance directly associated with these facilities. Energy costs vary with the number of $\mathrm{kWh}$ produced to serve customer usage, and include fuel, operation, and maintenance associated with converting fuel to electric energy and possibly the costs of purchasing power from other systems. Under the accounting cost analysis, no recognition is given to the fact that incremental or unit energy costs increase as total system output increases [245]. Customer costs are those related to the existence of specific customers and vary with the number of customers served. These costs include a portion of the primary and secondary distribution lines, transformers, and facilities required to provide service to the customer's location. Also included are metering costs and administrative costs associated with billing, accounting, and sales.

Costs which have been functionalized (generation, transmission, and distribution costs) and classified (demand, energy, and customer costs) are then allocated to customer classes. The three primary customer classes are industrial, commercial, and residential [246]. Allocation is made in proportion to each class' responsibility for each functionalized and classified cost. Energy-related costs are allocated on the basis of consumption by each class. Consumption amounts are available from billing data but are adjusted (increased) for line losses. Customer costs are allocated in accordance with the customer-related facility, metering, and billing costs associated with each class. The allocation of demand costs, which are frequently joint costs; i.e., costs incurred by an indivisible process that yields joint products, presents significant difficulty. Several methods are available for the allocation of demand costs [247]. The peak responsibility 
method allocates demand costs on the basis of each customer class' demand at the time of the system peak [248]. Another method, the noncoincident peak method, allocates demand costs proportional to the peak demand of the individual class regardless of when that de mand occurs [249].

Unit costs are then calculated for each class from the various demand, energy, and customer costs that have been allocated to it. Demand costs are converted to costs per $\mathrm{kW}$ of demand; energy costs are converted to costs per kWh of energy consumption; customer costs are converted to costs per customer. Rate structures can then be designed to generate revenues that recover the costs per unit of service. Practical considerations limit the applicability of a particular design. The most common is the widespread use of residential meters that measure only energy consumption. In this case, demand costs are collected through an energy or customer charge that is higher than the energy costs $[250]$.

\subsubsection{Time-Differentiated Rates Based on Total Accounting Costs}

If it is desired to have a rate structure containing rates that are differentiated by season and/or time of day, costs of service must also be differentiated. Where costs of service are based on accounting costs, time-differentiated ratemaking requires additional steps to the process.

The first additional step is to select a rating period for time differentiation. Rating periods can be seasonal, resulting in rates differing between winter and summer; or based on time of day, resulting in rates differing between daily on- and off-peak periods. The selection of a rating period begins with two principles: (1) periods of greater system load carry a greater portion of fixed costs per unit of demand, and (2) periods of greater system load carry a greater portion of variable costs per unit of consumption [251]. Historical load data are examined to determine months of high load; e.g., June through September for a summer peaking utility or December through February for a winter peaking utility. Such laad data are also used to determine the hours of the day to be defined as on- and off-peak [252].

The functionalization step requires the additional breakdown of operation costs into base load, cycling, and peaking periods. Costs must be allocated not only to customer classes, but also to the rating periods. Methods of cost allocation to rating periods include (1) the base-intermediate-peak method, (2) the Loss-of-Load-Probability (LOLP) approach, and (3) the peak responsibility method [253]. The base-inter mediate-peak method allocates a certain percentage of the base load, cycling, and peaking generation demand costs to three rating periods as predetermined (peak, secondary, off-peak). Under the second method, demand costs are allocated according to LOLP as grouped for convenience reasons (theoretically, since each hour of a year may have a different LOLP, there could be 8,760 rating periods). The peak responsibility method allocates the demand costs on the basis of a particular class' contribution to system peak. Traditionally, joint costs were not allocated to different products on a causal basis [254]. If off-peak electricity is a clear by-product of the production process engaged to meet peak demand, it can be justly stated that no capacity is constructed to produce the by-product, and capacity costs are thus chargeable solely to meeting peak demand. Therefore, no capacity charges and only energy charges should be imposed during off-peak periods [255].

Following the calculation of unit costs, a rate structure can be designed with differential charges based on seasonal and/or time-of-day periods. If ideally designed to charge by 
$\mathrm{kWh}$ of consumption and $\mathrm{kW}$ of demand, however, such structures require metering to measure at least demand as well as energy, and possibly the time when demand occurs and energy is consumed if time-of-day periods are used.

\subsubsection{Time-Differentiated Rates Based on Marginal Costs}

Still a different process is used in designing rate structures based upon marginal rather than accounting costs. Rates should be based predominantly upon long-run marginal costs or more conveniently long-run incremental costs rather than SRMC [256]. The logical starting point is to define a period within which incremental costs will be estimated. Such a period should be long enough to allow the electric system to be designed optimally for the expanded demand and energy requirements, but short enough so that reasonably accurate load and resource data are available from the utility. Periods from 5 to 10 years 1257 in advance of the time in which the rates are to become effective have been suggested. It follows that the incremental levels of demand and energy output would be those projected by the utility to occur during the selected incremental period. Seasonal and daily rating periods are defined previously for timedifferentiated rates based on total accounting costs.

The determination of marginal costs for demand, energy, and customer classifications varies with the method [258] being used. National Economic Research Associates used the following method for its Electric Utility Rate Design Study [259]. The long-range incremental cost of generating capacity is the cost of the unit added during the incremental period to accommodate peak demand. It is likely that this unit will be a gas turbine, pumped hydro storage project, or daily cycling fossil fuel generator [260]. The cost will be divided by the unit's capacity in $\mathrm{kW}$ to arrive at the marginal demand costs for the period. Transmission demand costs are projected for the incremental period and are unitized on the basis of (1) capacity for which the lines were planned, (2) additions to system peak demand, or (3) additions to system-generating capacity adjusted for various reserve margins. Distribution demand costs are those required to provide facilities necessary to accommodate demands that customers actually place on the system. The expenditures included in transmission and distribution demand cost projections are only those necessary to serve the increased demand, and costs associated with replacing retired equipment should not be included.

Incremental energy costs are the full and variable operating costs of the last machine online to serve demand requirements at the time investigated. This machine generally has the highest operating costs. Where such costs are obtained for every hour throughout the incremental period, they are averaged according to the weight given to anticipated sales during each hour. The end result is a cost $/ \mathrm{kWh}$ for each hour during the incremental period or as allocated to rating periods using a weighted average approach.

Marginal customer costs include the portion of the marginal distribution system costs (separate from demand costs) required to provide a system capable of connecting all customers and providing voltage but no power. This cost can be obtained by finding the cost of reconstructing the distribution system to serve a minimum demand to each customer, less the cost of transformers and conductors. Other customer-related marginal costs should be projected, including those attributable to accounting, sales, billing, and administration.

The allocation of costs to customer classes differs substantially from the process for time-differentiated rates based on accounting costs. The marginal demand costs are not 
allocated by customer classes. The unit charges for use by class are separated as follows: The marginal cost per $\mathrm{kW}$ of peak demand is adjusted to the cost per $\mathrm{kW}$ of mean peak demand of the class in accordance with the ratio of class mean peak demand to system peak demand. Marginal energy costs are already in a form suitable to the ratemaker $(\$ / \mathrm{kWh}$ for every hour or averaged for the predetermined on- and off-peak periods). Nondemand-related customer costs are annualized using the percentage carrying charge figure. Other customer expenses are added to this figure. A final step in the process is to allocate these various marginal costs to the rating periods.

\subsection{RATE REFORM}

Increased public concern over environmental protection, a need to conserve natural resources, and steadily increasing utility bills have led to an extensive review of traditional ratemaking practices. In the past, the electric utility industry has enjoyed decreasing average costs because of economies of scale and technological development [261]. This phenomenon justified the reduced electric rates for increased consumption. Long-run average costs for the utility industry have been increasing since the late 1960 s or early 1970s [262]. Significant factors contributing to this trend include (1) the rising cost of financing capital expenditures [263], (2) the rising cost of construction labor and materials [264], (3) pollution control equipment [265], (4) rapidly escalating fuel costs [266], and (5) delays associated with plants coming on-line [267]. At the same time, traditional rate structures providing quantity discounts have been challenged as inconsistent with sound economic principles and with environmental and conservation concerns. Alternative rate structures which have been proposed or adopted as a result of these challenges include inverted rates, flat rates, lifeline rates, demand rates, time-ofday (TOD) rates, and interruptible rates.

\subsection{RATE STRUCTURES}

\subsubsection{Deelining Block Rates}

The declining block rate structure has been the most widely used for residential and other small volume custorners [268]. This structure also provides a basis for portions of the rate structures applied to commercial and industrial customers. Where a separate customer or minimum charge is not provided in the rate structure, this charge is incorporated into the first energy block-typically $10 \mathrm{kWh}$. The rate structure is divided according to blocks of $\mathrm{kWh}$ energy consumption, and a decreasing price per unit of energy for successive consumption blocks is offered [269]. The effect of successively lower rates for each block of consumption is that both the incremental and average cost of electricity to the customer decreases with increasing consumption. The customer's bill is calculated by cumulating the charges incurred within each block beginning with the first. and continuing through the last $\mathrm{kWh}$ consumed in the billing period. Rate structures were designed on this basis to reflect the decreasing average costs associated with increasing consumption inherent in the electric utility industry and to promote consumption.

Iowa, Texas, Vermont, and the District of Columbia were, as of February 1978, the only jurisdictions disapproving the declining block rate structure [270]. Most state commissinns, however, hnve policies discouraging use of the declining block rate structure or have taken steps to eliminate it gradually [271]. For example, the Massachusetts commission has issued proposed regulations in which the declining block rate structure is specifically prohibited unless cost justified, that is, unless average costs in providing 
electric service decline with volume [272]. Cost justification is required by the Michigan commission in every rate case involving the declining block structure; the burden of proof is upon the utility [273]. The New York commission is opposed to the declining block structure unless it can be shown to be cost-based and economically justifiable [274]. In addition, Colorado, Hawaii, Louisiana, and Pennsylvania addressed the issue in rate hearings in late 1977 and early 1978 [275].

\subsubsection{Flat Rates}

Early flat rate structures charged the customer a lump sum regardless of the quantity consumed or time of use [276]. Now, however, the typical flat rate structure contains a customer or minimum charge plus a constant charge per $\mathrm{kWh}$ of electric energy consumption [277]. The flat rate structure design would be appropriate where average costs in providing service are neither decreasing nor Increusing. This design also serves as an alternate to the declining block structure, where it is the policy of the jurisdiction to eliminate it [278]. The flat rate structure promotes conservation goale since there exists no economic incentive to increase consumption.

Approximately 30 state commissions have experimented with or ordered flat rate structures or the flattening of declining block rates [279]. Approximately $50 \%$ of the state commissions have an implied or express policy encouraging the use of flat rate structures or encouraging the flattening of declining block rate structures [280]. A challenge in 1974 to the declining block rate structure proposed in an application for a rate increase by the Potomac Electric Power Co. (Pepco) resulted in a flattening of the declining block structure [281]. The commission required that Pepeo eliminate from its proposed rate schedules any increase on usage of $400 \mathrm{kWh}$ or less, and to transfer the requirement for that revenue to higher usage blocks [282]. A year earlier in New York, the commission ordered Consolidated Edison Co. to replace its declining block rate structures for residential (SC-1), and small industrial and commercial (SC-2) customers by a flat charge per $\mathrm{kWh}$ of consumption and a standard minimum charge [283]. Electric utilities in Alabama, Hlinois, and Ohio utilize a flat rate structure ouring the summers some utilities use this structure year-round [284].

\subsubsection{Inverted Rates}

An inverted rate structure is essentially the inverse of the declining block rate structure. The price charged per $\mathrm{kWh}$ of electric energy consumption $r$ ises with each successive block and results in both the incremental and average cost of electricity per $\mathrm{kWh}$ increasing with increased usage [285]. Where long-run average costs to provide service are increasing, this type of rate structure rellects the costs of the utility. The inverted rate structure is consistent with conservation goals. It has been argued that alternative conservation measures, such as insulation requirements, are more effective because the inverted structure could result in decreased total energy consumption without a resulting decrease in system peak demand. Such an effect would possibly cause an increase in unit costs and corresponding rates [286]. Where such rates have been in effect, commissions report positive feedback regarding faimess to consumers and the effects on energy conservation, and negative feedback from customers having allelectric homes or those who use large amounts of electricty for reasons of health [287].

Inverted rates are available in Idaho during the peakload season, and an electric utility in Florida offers an inverted residential conservation rate [288]. A form of rate inversion 
occurred in a 1972 Virginia Electric and Power Co. (Vepco) case in which a new rate block of consumption over $600 \mathrm{kWh}$ was priced higher than the preceding block, resulting in a U-shaped structure [289]. U-shaped rate structures have also been utilized in the District of Columbia, North Carolina, and South Carolina [290].

\subsubsection{Lifeline Rates}

Lifeline rates are those providing a low cost initial block for residential customers on the basis of need [291]. It is argued that everyone needs a certain amount of electricity and that society should provide for such needs by subsidizing a low consumption block. Most lifeline proposals identify the low consumption area ranging from 300 to $700 \mathrm{kWh}$, a quantity to cover lighting, heating, and cooking [292]. The lifeline concept was designed to help the poor and elderly who generally must pay a greater percentage of their income for utility services. Studies have shown that low consumption users, however, are not necessarily members of the low income and elderly classes [293].

One lifeline proposal recognizes a need not to burden the consumption block immediately following the lifeline amount and seeks to obtain the recoverage for subsidization in the tail end blocks [294]. The intermediate rate step is necessary to avoid penalizing low income consumers whose electric energy needs exceed the amount provided for in the lifeline block [295]. The lifeline block is subsidized and would be provided at below cost. The following or intermediate block would be priced to cover the actual cost-ofservice, and subsidization for the initial block is recovered from the higher blocks [296].

Jurisdictions differ as to whether lifeline rates are valid or are in violation of state antidiscrimination statutes because of the subsidizing by higher usage blocks of the lifeline block. Orders by commissions in the District of Columbia, Pennsylvania, and Rhode Island limited rate increases in the residential class to usage blocks greater than $450 \mathrm{kWh}, 500 \mathrm{kWh}$, and $300 \mathrm{kWh}$, respectively [297]. The effect of these orders in addition to structure flattening, is to establish a quasi-lifeline provision, at least regarding rale increyses, even though higher usage blocks may continue to be priced lower per unit. A one-year lifeline demonstration project was undertaken by Maine in 1976 and 1977 [298]. Late in 1977, a similar experiment was underway in Arizona, in which, rather than having a low-priced initial consumption block, the customer charge was forgiven for residential customers who used less than $700 \mathrm{kWh}$ a month [299]. In a 1970 application by Consolidated Edison Co. of New York to increase rates, the state commission rejected the company's proposal to continue the present minimum charge for service to residential customers over age 65, rather than to increase the charge-as was being done for the remainder of the residential class [300]. In a similar application by Philadelphia Electric Co. in 1971, intervenors contended that ability to pay should determine whether certain customers are subject to rate increases [30l]. The argument was refused, and the state commission held that there could be no preference to any customer based on ability to pay, under the public utility law [302]. The New Hampshire commission held that a rate structure providing an initial amount of electricity to residential customers at low rates and requiring a subsidy from higher use customers would be discriminatory [303]. It was further stated that a subsidy for utility service for low income customers should be directly provided through legislation rather than indirectly through utility rates [304]. In an investigation of preferential treatment to the poor and elderly and a lifeline rate for all residential customers, the Oregon Public Utility commissioner ruled that he lacked the authority to prescribe discounts in favor of aged or poor persons [305]. It was further found that commission-ordered discount rates are discriminatory, and therefore, unlawful under the Oregon Public Utility Law [306]. 
The commissioner found that such a structure would benefit the poor and elderly only if they, as a class, used less energy than other consumers. The proposed lifeline was rejected on the ground that it would be discriminatory against equally needy low income customers who must use more than the minimum amount of energy [307].

Some commission decisions approve the concept of lifeline rates. In 1975, the California legislature passed the Miller-Warren Energy Lifeline Act [308]. This Act required the state commission to establish lifeline quantities of gas and electricity necessary to supply the minimum energy needs of the average residential user for space and water heating, lighting, cooking, and food refrigeration [309]. The Act also required that every gas and electric utility file a schedule of rates and charges providing a lifeline rate [310]. In 1976, The California commission granted a proposal to establish lifeline rates to give effect to the Miller-Warren Energy Lifeline Act and to encourage conservation of energy [311]. Lifeline rates designed to promote energy conservation and to provide relief to elderly or poor consumers, were adopted by the South Dakota commission in 1977 [312]. The commission accepted the staff's recommendation not to wait for the legislature to act upon social welfare legislation because such a delay would fail to provide relief to the company's needy customers and to provide energy conservation incentives [313].

\subsubsection{Demand Rates}

Demand rate schedules have been referred to as Hopkinson rates or demand/energy rates. This type of rate schedule has been widely used for medium and large commercial and industrial customers [314], but also finds application in the residential sector as well [315]. Typically, the demand schedule provides for a two-part rate consisting of separate charges for maximum demand and energy usage. The demand and energy charges can take flat, inverted, or declining block forms. A customer's maximum demand can be either estimated or measured. The rate structures discussed previously require only the use of a typical watt-hour meter [316]. Where it is desired to measure the maximum $\mathrm{kW}$ demanded during a given billing period, it is necessary that the customer be equipped with a special meter [317]. The billing demand is generally the customer's peak 15 to 30 minute demand as recorded during the billing period [318]. Since this rate structure contains a demand element, the average rate a customer pays varies directly with his individual laad factor [319]. As the customer increases his energy consumption without a corresponding increase in peak demand, or decreases his peak demand without a corresponding decrease in energy consumption, his load factor will increase and his average rate will decrease [320]. As the customer's load factor decreases because of his yatter'n of use, his average rate will correspondingly increase. The reason for implementation of this rate structure by the electric utilities is to encourage high load factor uses, with the theory that such uses will, in the aggregate, contribute to system load factor improvement. A customer who cannot vary his demand, however, is encouraged by this rate structure to increase energy consumption in order to improve load factor. Such an encouragement is contrary to the goal of energy conservation.

In 1933, the Massachusetts Department of Public Utilities ordered that a demand charge of $\$ 1.50$ per $\mathrm{kW}$ was applicable to customers having demands in excess of $2 \mathrm{~kW}$ [32l]. The Supreme Court of Illino is held that the application of a demand charge along with an energy charge in substitution of the standard rate was not discriminatory, and further stated that the demand charge was necessary to recover a portion of the fixed costs incurred by the utility in meeting the customer's demand regardless of the amount of power consumed [322]. In an application by two electric companies to the New 
Hampshire commission for authority to increase rates, customer dissatisfaction with an excess demand charge for the residential sector led to its elimination [323].

Where the demand charge is based upon the customer's noncoincident peak demand rather than his contribution to the system peak demand, load factor improvement by the customer may not necessarily contribute to overall system load factor improvement [324]. If a customer, in response to the demand rate structure, attempts to even out his distribution of demand by either (1) increasing his off-peak demand, or (2) decreasing his on-peak demand, depending on the time of the system peak relative to the customer's peak, this shifting could work to decrease system load factor. If the customer's off-peak demand corresponds with the system's on-peak demand, case (1) would result in an increase to system peak demand [325]. If the customer's peak demand corresponds with the system's off-peak demand, case (2) would result in a less even distribution of demand for the system. The demand rate structure can work well if all customers distribute their loads evenly [326]. A demand rate structure designed for the greatest potential for improving overall system load factor, would have demand charges according to coincident demand or in accordance with a customer's contribution to system peak demand [327].

\subsubsection{Time-of-Use Rates}

Time-of-use rate structures are also known as time-of-day (TOD) or rates based on peak load pricing (PLP) [328]. Time-differentiated rates can be based on seasonal on- and offpeak periods or daily on- and off-peak periods. Seasonal pricing refers to pricing electric service to account for varying costs to the utility of providing the service at different times during the year; TOD pricing reflects the varying costs of providing electric service at different times during the day. It is desired that these rates are intended to shift consumption from peak to off-peak periods and thereby slow the need for new capacity additions. Also, with significant differentials between the price charged for demand and energy at peak periods and that charged at off-peak periods, customers should be induced to decrease peak demand and thereby increase their load factors. With less demand imposed on the system at peak periods, operating costs will be lower, resulting in postponement of rate increases [329]. The scheme seeks to penalize peak use in the short run and alter use patterns in the long run with resulting load factor improvements and economizing on system capacity [330]. Under TOD rates, the customer is given a method to reduce his electric bill by shifting demand and energy consumption to off-peak periods. Contrary to demand rate structures which may act to decrease the system's load factor, a TOD rate structure will generally improve the system load factor unless consumption patterns have so changed to reverse the on- and off-peak periods. A typical TOD rate structure may contain varying de mand and energy charges for daily onand off-peak periods and for seasonal on- and off-peak charges [331]. Where demand charges are not used, energy charges incorporating the demand costs can have any of the forms discussed previously.

The adoption of seasonal or TOD rates has several advantages and disadvantages. The advantages include (1) avoidance of additions by a reduction in future peak loads [332], (2) savings in operating costs, primarily fuel costs, when peak demand is served by more efficient base load and cycling plants rather than peaking units [333], (3) encouragement of load leveling [334], and (4) the provision of direct pricing signals to the consumer regarding the marginal costs his consumption at various times imposes upon the electric utility [335]. Inherent in this is the concept that, if the price of a commodity is set equal to its marginal cost, society's scarce resources will be allocated so as to maximize the 
satisfaction of consumers [336]. Opponents to the establishment of TOD rate structures based on long-run incremental costs (LRIC) argue that (1) marginal cost pricing of electric service does not produce optional results unless all alternatives for this service are priced at marginal cost [337]; (2) in a period of decreasing average costs, marginal cost pricing yields revenues falling short of the revenue requirement, and in a period of increasing average costs, marginal cost pricing yields revenues in excess of the revenue requirement [338]; (3) peak shifting or needle peaks will occur necessitating periodic revisions in pricing structures contrary to the objective of rate structure stability [339]; (4) the effects of TOD pricing, highly dependent on price elasticity of demand, are not readily ascertainable and customer response is uncertain [340]; (5) traditional notions of fairness in allocating demand costs are not promoted [341]; and (6) the costs of administration and metering outweigh any benefits that may be realized [342].

With recent increases in the prices of oil, this form of energy alternative may now be priced at its marginal cost. While the cost of natural gas remains priced below its marginal cost, it is unlikely that this alternative would oruse a shift from electric consumption to gas consumption in light of its limited availability [343]. Where the revenues yielded by a long-range incremental costs pricing concept exceed those legally allowed by the revenue requirement, several approaches have been suggested that correct the inconsistency [344]. The suggested approaches include (1) taxing away the surplus; (2) adjusting the customer or service charges; (3) varying marginal prices in inverse proportion to the customer's price elasticity of demand [345]; i.e., charging customers with higher elasticities of demand lower prices for their electric service; and (4) adjusting all rates by the same percentage. Another method of revenue adjustment involves the lifeline concept. This method could give rate reductions to persons determined to be needy, or could call for rate reductions for lifeline quantities [346]. Since customers have slow reactions when presented with pricing differentials, peak shifting does not appear to be a significant problem. Probable shifting of ronsımer demand will not be so significant that off-peak periors will bocome park periods [347]. Some uncertainty of effects resulting from implementation of TOD rates may be dispelled when results of peak pricing experiments presently underway are available [348]. On the other hand, much data has been available for some time regarding the peak load pricing rate structures implemented in Europe several years ago [349].

Additional costs in implementing a TOD rate structure must be weighed against the benefits such a structure will convey. Where metering equipment is already installed or readlly available, as is the case for large industrial and commercial users in many areas, implementation of TOD rates should begin in these sectors rather than for smaller users where meter retrofit would require considerable expense. The administrative costs of additional meter reading, billing expenses, and reset procedures for timing devices following unplanned outages can be significant and should be considered. For utilities already experiencing near optimal generating efficiencies or high load factors, costs to implement TOD rates may outweigh the benefits conferred [350].

\section{Recent Cases}

A recent decision by a New York appellate court addressed the faimess of TOD rates [351]. TOD rates applicable to a limited number of Long Island Lighting Company's (Lilco) large customers were held unlawfully discriminatory in New York State Council of Retail Merchants v. Public Service Commission [352].

Early in 1975, the New York commission began investigating the desirability of implementing peak load pricing based on incremental costs, and ordered the state's major 
elec tric utilities to prepare TOD rate designs for customers whose meters could measure loads according to hour. Marginal or incremental costs were held to provide a reasonable basis for determining the rate structure of electric utilities [353]. Lilco had pending a rate case in which proposed TOD rates for its largest commercial and industrial customers were submitted to the commission for review and approval [354]. The proposed TOD rates and associated cost justification materials were used by Lilco in the generic rate design case in support of marginal cost pricing theory. The commission's decision in the Lilco case approved the proposal to initiate mandatory TOD rates for the company's largest commercial and industrial customers [355].

The TOD rate structure used three rating periods. Period I was the off-peak period from midnight to 7:00 a.m. throughout the year. Period II was the on-peak period, from 10:00 a.m. to 10:00 p.m., Monday through Saturday, June through September. Period III encompassed all the remaining hours of the year [356]. Based on marginal costs, a differential in demand charges of 8:1 was established between the peak and intermediate periods with no demand charge for off-peak usage. Energy charges were established at differentials of 1.2 to $l$ between peak and intermediate periods and 1.6 to 1 between peak and off-peak periods [357]. The TOD rate classification applied to commercial and industrial customers whose demand exceeded $750 \mathrm{~kW}$ in two of the preceding 12 months.

It was argued by the Retail Merchants that the rate levels within the TOD rate should be based on the inverse price elasticity rule. The commission rejected this argument because differences in elasticity among customers in the group were not established in the record [358]. It was also argued that application of the new rate to only the largest customers was unduly discriminatory in that TOD rates should be applied to all customers, or at least should be initiated in the residential sector, because of allegedly greater benefits for these customers. This argument was also rejected by the commission, because the plan was to begin with larger customers and progress to smaller customers in light of the enormous metering costs involved [359].

The New York Appellate Division held that:

[a]pplication of the instant SC 2-MRP rates to a limited classification without some cost justification therefor would produce an undue preference or advantage favoring those who are not within that class in violation of subdivision 3 of seetion 65 of the Public Bervice Law. [360]

The court further stated that ratemaking which:

departs from cost allocations must have a rational basis and here there is inadequate support to transform conclusions about the elasticity of time demand for electric service or the difficulty of metering into definite rates .... [36 1]

Lilco and the state commission appealed. In seeking reversal of the lower court's ruling and affirmance of the determination of the commission mandating TOD rates, the commission is arguing that (1) TOD rates better reflect Lilco's costs of servicing the affected customers; (2) rates such as TOD that are more closely aligned to the cost of providing service will help to reduce peak demands and limit the use of high cost fuel; (3) improvements in the rate structure cannot be applied to all customers at once; and (4) classification of the customers was reasonably established on the basis of the quantity used, the time of use and the purpose for use, consonant with the Public Service Law [362]. A decision on the appeal is expected in 1979. 
Long-run incemental costs as a basis of electric utility rate structure design received a thorough exposition in Madison Gas and Electric Co. [363]. Four basic ratemaking principles were listed by the Wisconsin commission: (1) rates should promote an efficient allocation of resources and discourage wasteful energy use; (2) rates should not be unduly discriminatory; (3) stable revenues should result from rates; and (4) rates should reflect historical continuity [364]. It was generally agreed that the first principle implies that rates should reflect the marginal cost of providing service. The commission held that:

the appropriate bench mark for the design of electric rates ... is marginal cost as represented by the practical variant longrun incremental cost. If electric rates are designed to promote an efficient allocation of resources, this is a logical starting point. [365]

Having no direct evidence concerning the practicability of implementing peak-load pricing on a TOD basis, the commission ordered the company to investigate the feasibility of such a pricing system [366]. The level of revenues calculated to result from a pricing scheme based on incremental costs was found approximately equal to the revenue requirement. This implied that the company was not in a period of increasing costs and pointed to the desirability of flattening the rate structure. The ultimate result for the residential sector was a flat rate per $k W h$ consumed for the summer and a winter differential of $\$ 0.007 / \mathrm{kWh}$ for consumption over $1,000 \mathrm{kWh}$ [367].

More recently, TOD rates and rates having seasonal differentials have been approved by commissions on mandatory, optional, or experimental bases in nearly every jurisdiction [368]. Individual companies have filed TOD rates in 15 states. Commissions in 11 states have ordered that TOD rates be filed by individual companies. Commissions in 11 states have approved TOD rates for some or all customer classes [369]. For example, in California, TOD rates are in effect for customers with monthly demand exceeding $4,000 \mathrm{~kW}$. It is planned that these rates will be extended to other customers, eventually including all customers whose monthly demand exceeds $500 \mathrm{~kW}[370]$. Funding was approved by the Federal Energy Administration (FEA) for a joint Wisconsin Public Service Corp./Wisconsin Public Service Commission study involving TOD rates for approximately 700 residential customers. On $18 \mathrm{Feb} 77$, the state commission ordered $W$ isconsin Public Service Corp. to establish temporary TOD rates for these selected residential customers [371]. The residences were equipped with special TOD recording meters. Eleven schedules were developed for both a sampling of residential urban and residential rural customers. The schedules consisted of TOD rates with varying peak and off-peak periods including seasonal differentials, flat rates with a winter/summer differential, and three-part rates consisting of flat customer and energy charges and seasonal demand charges for peak periods only. The rates became effective the first billing period after $22 \mathrm{Apr} 77$, and will continue for three years, during which time data will be obtained from every customer on the experimental rates.

Early in 1978, an interim order of the Wisconsin commission authorized Wisconsin Electric Power Co. (Wepco) to implement TOD rates for large residential, general primary, and large commercial customers who by mid-1979 will account for $38 \%$ of Wepco's peak system demand and $47 \%$ of its energy usage [372]. In the residential sector, TOD rates were made mandatory for the company's 500 largest kWh-usage customers. The applicable rate consists of a fixed customer charge and varying energy charges depending upon time of use [373]. A final order was subsequently issued by the commission authorizing TOD application to an additional 77 of the largest kWh-usage residential customers [374]. In the final order, the residential TOD rates as established by the interim order were found just and reasonable [375]. 


\subsubsection{Interruptible Rates}

Interruptible rates are potentially beneficial to solar users not requiring auxiliary energy during system peaks. Interruptible rates are for customers who agree to have their use curtailed by the electric utility during peak laading or periods of system emergencies [376]. The utility can reduce peak loading by interrupting service to some customers during system peaks, thereby reducing capacity demand and, entitling customers served under this rate structure to lower rates.

Traditionally, this type of rate has been offered to industries willing to encounter the risk of service interruptions in order to receive lower rates [377]. In order to interrupt a customer's load, the utility utilizes radio-controlled devices or limiting circuit breakers [378]. For commercial and residential solar heating and cooling applications, costly radio-controlled devices would not be necessary; time-controlled circuit breakers could be used within the building to interrupt auxiliary service during peak periods.

The cost savings resulting from service to controlled users over the costs imposed upon the system by noncontrolled customers can be computed on the basis of either marginal or accounting costs [379]. Under this form of rate structure, a solar building would probably forego only a few days of auxiliary energy service per year [380]. The savings to a customer with a $1400 \mathrm{ft}^{2}$ residential dwelling served by an eastern utility under interruptible rates could be as high as $\$ 600$ per year [381].

Court and commission decisions have confirmed the validity of offering lower rates for interruptible service. In Wolf v. United Gas Public Service Co. [382], bakery owners charged that interruptible rates were discriminatory. The court affirmed the rates, holding that a customer cannot complain that a gas rate is discriminatory unless it is clearly shown that others operating under similar conditions are charged less [383]. It was noted by the court that the gas company's stipulation, entitling it the privilege of cutting off service in emergencies which jeopardize the supply for domestic and comm ercial uses, was itself sufficient to justify the cheaper rate [384]. In a similar rate discrimination case, a coal operator's association contended that a gas company's interruptible rates were discriminatory and resulted in unfair competition with other types of fuel [385]. The Illino is commission disagreed [386]. 


\section{SEPI}




\section{SECTION 4.0}

\section{EFPECT OF RATES ON SOLAR SYSTEM ECONOMICS}

It is highly likely that some form of conventionally fueled auxiliary system will be needed to provide a solar building's heating and cooling needs during periods of adverse weather. Because utility system loads can vary with solar auxiliary demands, utilities may need to design a separate rate structure to apply to solar users. The variety of rate structures implemented has a significant effect upon solar system economics and may need to be taken into account in solar system designs. Conversely, the type of solar design used may govern the kind of rate structure the utility implements; e.g., a system needing only off-peak auxiliary energy could be given off-peak rates.

\subsection{DEMAND/ENERGY EIECTRIC RATES}

In October 1975, the Colorado commission found a mandatory demand energy rate [387], applicable to residential service where electric heating is the principal source of heat or the primary backup source to another form of heat, to be just and reasonable [388]. The rate was designed in part to yield revenues to cover the company's extra costs incurred in providing auxiliary electric service to solar-equipped facilities [389]. Intervenors and solar advocates contended that the demand charge, based on a customer's noncoincident peak demand, would be discriminatory toward those solar customers whose peak demand did not coincide with that of the company's system. Also, the demand charge, designed to penalize those customers having load factors less than $22 \%$, was certain to penalize solar customers in that solar system auxiliaries with low energy consumption are characterized by a low load factor [390].

After the initial decision, a complaint proceeding challenging the residential demand/energy rates was instituted on $5 \mathrm{Apr}$ 76, by the Home Builders Association of Metropolitan Denver, against Public Service Co. of Colorado [391]. The commission, by its own order, instituted a second case to investigate the rates and invited intervention by interested persons [392]. Leave to intervene was granted by the commission to the Environmental Defense Fund and the Architects' Group, who argued the inappropriateness of the demand/energy rate to solar customers. Because both cases involved reasonableness of the demand rates, the cases were consolidated. Home Builders contended that the demand rates were unjust and unreasonable because they were implemented by the company without sufficient data or experimentation, and further alleged that the demand rates unlawfully discriminated between residential electric users subject to the rates and those who were not. Home Builders requested that the demand rates be made optional and that the company fully investigate the effects of the new rates.

Testimony presented by the intervenors advocated the use of marginal cost pricing by the implementation of TOD or flat rates, arguing (1) the demand rates made no allowance for timing of customer demand and ulility cost variations with time; (2) accurate price signals were not provided to consumers regarding their consumption patterns; (3) in many instances, such as with automatic electric heat, hot water, and air conditioning, consumers are unable to control demand and manage loads to take advantage of the demand rates; and (4) the economics of energy storage systems, including solar, would be threatened by the demand rates. Specifically, solar advocates testified that (1) TOD or flat rates would be less discriminatory toward solar users whose demand and energy requirements (generally occurring during evening hours) occurred noncoincidentally with the system peak; (2) if a peak/off-peak differential in charges resulting from the use of a 
TOD rate structure was substantial, solar designers would design systems to keep backup demands entirely off the system's peak; and (3) the demand rate if perpetuated would hinder the development and utilization of alternative energy sources, and insure that the alternative systems that do emerge are not as efficiently designed as they could be under a more sensible rate structure [393].

The commission decided that the new demand rates were to be provided on an optional basis [394]. The issues regarding solar rates and the applicability of TOD rate structures were left to be considered in the ongoing generic hearings.

The effect of the demand/energy rate can be seen by comparing the monthly utility bills of an all-electric home and a solar-equipped home under the demand rate [395], the allelectric declining block rate [396], and the general residential service declining block rate [397] of Public Service Co. of Colorado (effective during the fall of 1978) [398]. Table 4-1 indicates the heat requirements of a typical single family, all-electric residence and a 70\% solar-heated residence losing 10,000 Btu [399] per degree day. The data corresponds to a well-insulated $2,000 \mathrm{ft}^{2}$ house. Denver weather data for 1974 was used to ascertain the monthly electric energy consumption and peak demand for both types of houses. It was assumed that all electric usage other than space heating created a peak demand of $10 \mathrm{~kW}$ and caused an energy consumption of $900 \mathrm{kWh}$ each month. It was further assumed that a heating peak demand of $10 \mathrm{~kW}$ occurred coincidentally with the peak demand of other electric usage, but that $50 \%$ of the other usage demand was applied toward heating the house. Therefore, peak electrical demand ranged between 10 and $15 \mathrm{~kW}$. For the solar house when auxiliary heat was necessary, it was assumed that the lowest monthly temperature occurred at the end of an extended cloudy and cold period and that the electric auxiliary created the same heating demand as the heating equipment in an all-electric home [400].

Table 4-2 provides a comparison of the monthly and annual electric bills for the allelectric and solar houses under each of the three rate structures. Under both the RH-1

Table 4-2. COMPARISON OF ELECTRIC UTIITYY BILIS FOR 10,000 Btu/DEGREE DAY ALL-ELECTRIC AND 70\% SOLAR-HEATED HOMES IN DENVER

\begin{tabular}{|c|c|c|c|c|c|c|}
\hline \multirow[b]{2}{*}{ Month } & \multicolumn{3}{|c|}{ All-Electric Home Bill } & \multicolumn{3}{|c|}{ 70\% Solar Home Bill } \\
\hline & $\mathrm{RD}-\mathrm{1}^{\mathrm{a}}$ & $\mathrm{RH}-\mathrm{l}^{\mathrm{b}}$ & $\mathrm{R}-1^{\mathrm{C}}$ & $\mathrm{RD}-\mathrm{l}^{\mathrm{a}}$ & $\mathrm{RH}-1^{\mathrm{b}}$ & $\mathrm{R}-\mathrm{I}^{\mathrm{C}}$ \\
\hline Jan & $\$ 98.78$ & $\$ 142.40$ & $\$ 123.70$ & $\$ 82.93$ & $\$ 48.52$ & $\$ 85.57$ \\
\hline Feb & 78.33 & 106.17 & 92.22 & 61.61 & 59.85 & 51.96 \\
\hline Mar & 72.36 & 93.17 & 80.92 & 54.75 & 44.41 & 38.55 \\
\hline Apr & 61.78 & 79.84 & 69.33 & 47.70 & 40.58 & 35.22 \\
\hline May & 49.33 & 49.79 & 43.22 & 45.31 & 37.43 & 32.48 \\
\hline Jun & 47.27 & 44.08 & 38.26 & 45.31 & 37.43 & 32.48 \\
\hline Jul & 45.31 & 37.43 & 32.48 & 45.31 & 37.43 & 32.48 \\
\hline Aug & 45.57 & 38.46 & 33.38 & 45.31 & 37.43 & 32.48 \\
\hline Sep & 51.14 & 54.81 & 47.58 & 45.31 & 37.43 & 32.48 \\
\hline Oet & 56.44 & 69.61 & 60.44 & 45.31 & 37.43 & 32.48 \\
\hline Nov & 76.23 & 103.90 & 90.24 & 60.68 & 60.82 & 52.81 \\
\hline Dec & 83.59 & 123.39 & 107.18 & 68.33 & 81.14 & 70.47 \\
\hline TOTALS & $\$ 766.18$ & $\$ 943.05$ & $\$ 818.95$ & $\$ 647.86$ & $\$ 609.90$ & $\$ 529.46$ \\
\hline
\end{tabular}

${ }^{a}$ Demand/Energy Rate

$b_{\text {All-Electric Declining Block Rate }}$

${ }^{C_{G}}$ eneral Residential Declining Block Rate 
Table 4-1. COMPARISON OF HEAT AND ELECTRICAL POWER REQUIREMENTS FOR 10,000 Btu/DEGREE DAY ALL-ELECTRIC AND 70\% SOLAR-HEATED HOMES IN DENVER BASED ON 1974 WEATHER DATA ${ }^{a, b}$

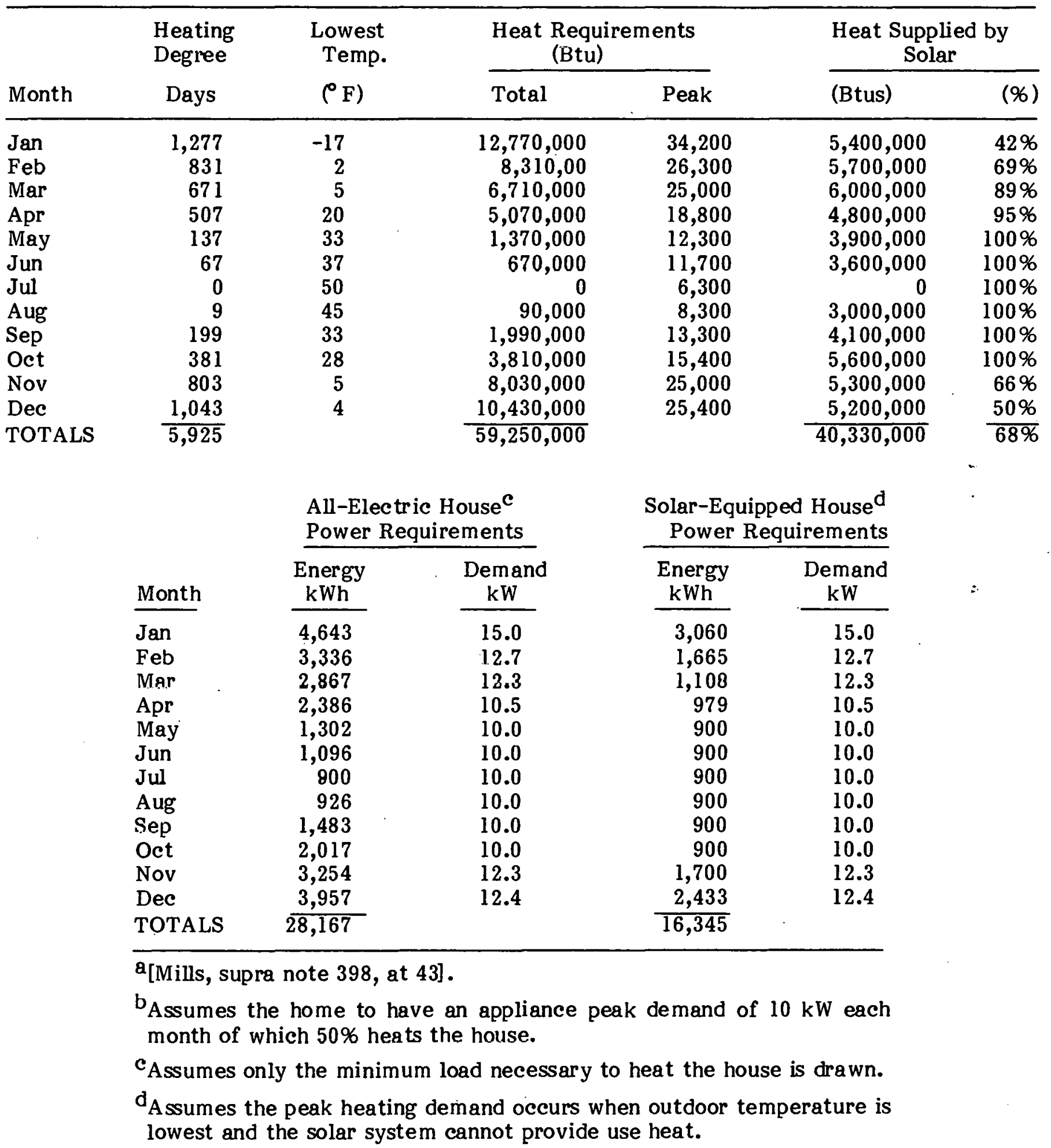


and $\mathrm{R}-1$ declining block rate structures, a $70 \%$ solar-heated home yields a savings of $35 \%$ on the annual electric utility bill. The percentage savings under the demand/energy rate, however, drops by more than half to only 15\%. This reduction in savings may be significant enough to change a marginally economic solar system into an uneconomic investment [401]. Tables 4-1 and 4-2 also reveal that the demand/energy rate (RD-1) will result in a monthly bill savings (1) over the electric heating rate ( $\mathrm{RH}-\mathrm{l}$ ) only if the customer's load factor is greater than approximately $18 \%$, and (2) over the residential service rate (R-1) only if the customer's load factor is greater than approximately $23 \%$. Only during the months of January and December did the solar house exceed a load factor of $23 \%$, thereby suving on the monthly bill under the demand/energy rate compared to both declining block rates. If economically feasible, a type of demand limiter or controller should be considered by the solar customer in order to improve on load factor and thereby take advantage of the demand/energy rate. It should be noted that the residential heating all-electric declining block rate ( $\mathrm{RH}-1$ ) results in monthly bills that are $15 \%$ higher than those under the general residential declining block rate $(\mathrm{R}-1)$ for both the all-electric and solar houses.

\subsection{STANDBY SERVICE GAS RATES}

The Mountain Fuel Supply Co. in Salt Lake City, Utah (a natural gas utility) maintains a standby service rate [402] in addition to its other rate schedules. From an inspection of the applicability of the various rates, it appears that the standby service rate would apply to a solar user who utilizes natural gas to fire his auxiliary heating system [403] .

Table 4-3 provides a comparison of the monthly heat and gas requirements for a gasheated home and a $70 \%$ solar-heated home based on 1974 Denver weather data. To calculate the gas requirements, it was assumed that the gas had a heat value of $1,000 \mathrm{Btu} / \mathrm{ft}^{3}$ of natural gas. It was further assumed that the furnace had a conversion efficiency of $30 \%$.

Tuble 4-3. COMPARISON OF HEAT AND NATURAI. (IAS RFQUIREMENTS FOR 10,000 Btu/DEGREE DAY GAS-HEATED AND 70\% SOLARHEATED HOMES BASED ON 1974 DENVER WEATHER DATA

\begin{tabular}{|c|c|c|c|c|c|}
\hline \multicolumn{2}{|c|}{ Heat Requirements ${ }^{a}$} & \multicolumn{2}{|c|}{ Heat Supplied by Solar ${ }^{\mathrm{a}}$} & \multicolumn{2}{|c|}{ Gas Requirements $\left(\mathrm{ft}^{3}\right)^{\mathrm{b}, \mathrm{c}}$} \\
\hline Month & (Btu) & (Btu) & (\%) & Gas Home & Solar Home \\
\hline Jan & $12,770,000$ & $5,400,000$ & $42 \%$ & 25,540 & 14,740 \\
\hline Feb & $8,310,000$ & $5,700,000$ & $69 \%$ & 16,620 & 5,220 \\
\hline Mar & $6,710,000$ & $6,000,000$ & $89 \%$ & 13,420 & 1,420 \\
\hline Apr & $5,070,000$ & $4,800,000$ & $95 \%$ & 10,140 & 540 \\
\hline May & $1,370,000$ & $3,900,000$ & $100 \%$ & 2,740 & 0 \\
\hline Jun & 670,000 & $3,600,000$ & $100 \%$ & 1,340 & 0 \\
\hline Jul & 0 & 0 & $100 \%$ & 0 & 0 \\
\hline Aug & 90,000 & $3,000,000$ & $100 \%$ & 180 & 0 \\
\hline Sep & $1,990,000$ & $4,100,000$ & $100 \%$ & 3,980 & 0 \\
\hline Oet & $3,810,000$ & $5,600,000$ & $100 \%$ & 7,620 & 0 \\
\hline Nov & $8,030,000$ & $5,300,000$ & $66 \%$ & 16,060 & 5,460 \\
\hline Dec & $10,430,000$ & $5,200,000$ & $50 \%$ & 20,860 & 10,460 \\
\hline TOTALS & $59,250,000$ & $40,330,000$ & $68 \%$ & 118,500 & 37,840 \\
\hline
\end{tabular}

$\mathrm{a}_{\text {Heat figures obtained from Table } 4-1 .}$

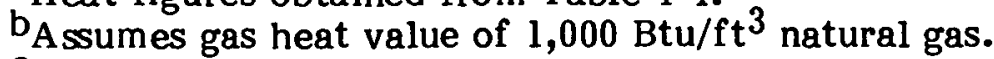

Assumes $50 \%$ efficiency on furnace. 
The gas requirement figures from Table 4-3 were applied to the Mountain Fuel Supply Co. general service (GS-1) [404] and firm standby service (F-3) rates to compare utility bills for both types of homes. This comparison is illustrated in Table 4-4. Even though heat requirements for homes in Salt Lake City were not used, the figures provide a reasonable relative comparison of bills under the two applicable rates. Under the general service rate, a $70 \%$ solar-heated home provides a savings of $58 \%$ on the annual gas utility bill compared with the annual utility bill of the gas-heated home. If the solar user is required to take the firm standby service rate, however, no savings in the annual utility bill results from the use of solar heating. In fact, the solar home's annual utility bill under the firm standby service rate is $19 \%$ higher than the gas-heated home under the general rate, and $183 \%$ higher than it would be under the general service rate. The firm standby service rate, if mandatory for solar-equipped buildings, is a definite barrier to the use of solar energy.

Table 4-4. COMPARISON OF GAS UTHITY BILIS FOR 10,000 Btu/DEGREE DAY GAS-HEATED AND 70\% SOLAR-HEATED HOMES

\begin{tabular}{|c|c|c|c|}
\hline \multirow[b]{2}{*}{ Month } & \multirow{2}{*}{$\frac{\text { Gas-Heated Home Bill }}{\text { GS-1 }^{\mathrm{a}}}$} & \multicolumn{2}{|c|}{$70 \%$ Solar-Heated Home Bill } \\
\hline & & GS-1 $1^{a}$ & $F-3^{b, c}$ \\
\hline Jan & $\$ 40.80$ & $\$ 25.62$ & $\$ 33.91$ \\
\hline $\mathrm{Feb}$ & 28.26 & 12.24 & 22.37 \\
\hline Mar & 23.76 & 5.70 & 17.77 \\
\hline Apr & 19.15 & 4.30 & 16.70 \\
\hline May & 8.10 & 4.30 & 16.05 \\
\hline Jun & 1.88 & 0 & 16.05 \\
\hline Jul & 0 & 0 & 16.05 \\
\hline Aug & .25 & 0 & 16.05 \\
\hline Sep & 5.59 & 0 & 16.05 \\
\hline Oet & $10.4 \dot{2}$ & 0 & 16.05 \\
\hline Nov & 27.47 & 12.57 & 22.67 \\
\hline Dec & 34.22 & 19.60 & 28.73 \\
\hline TOTALS & $\$ 199.90$ & $\$ 84.33$ & $\$ 238.45$ \\
\hline
\end{tabular}

\subsection{ELECTRIC SERVICE ADVANCE DEPOSITS}

The City of Columbia, Missouri, owns and operates an electric distribution system to provide electricity to its residents. In September 1977, the city passed an ordinance pertaining to the supply of electricity for standby or supplemental purposes [405], providing that customers desiring electric service for standby or supplemental purposes 
are required to enter into an electric service agreement with the city. This agreement states:

WHEREAS, the facilities and premises to be connected for electric service will utilize solar energy for the purpose of comfort space heating, and WHEREAS, Customer desires to install electric space heating facilities and equipment for standby and/or supplementary purposes, such standby and supplementary equipment to be utilized only when weather conditions are such that the solar system can not provide the energy required to heat Customer's premises and maintain the desired temperature ....

2. The rate charged customer by City, for electric energy shall be the same as that rate which is charged to other Customers in the same class who utilize a form of energy other than electricity for comfort space he. ting ....

6. At the time of receiving service Customer shall deposit with city, the amount of $\$ 200.00$ in addition to the regular service deposit. This additional deposit shall be used for the purpose of adjusting the Customer's charges in the event a higher rate is adopted [for standby service to solar equipped facilities] .... Should City find that a higher rate is not warranted this additional deposit will be credited to Customer's Account or refunded. [406]

In short, a solar user in Columbia is required to pay an additional advance deposit of $\$ 200$ to cover a potential increased solar rate, and cannot take advantage of the promotional electric heating rate [407] even though an electrical backup is utilized [408].

For comparison purposes, the electric energy requirements of Table 4-1 were applied to the Columbia rates to ascertain the effect on solar system economics. Table 4-5 illustra tes monthly ulility bills for (1) an all-oleotric home under the promotional electric heating rate, (2) a $70 \%$ solar home under the rate a solar facility is required to take, and (3) a 70\% solar home under the promotional electric heating rate. If the solar home could take advantage of the promotional electric heating rate, a $34 \%$ savings in the annual electric utility bill would result, compared to the annual bill for an electric heat home. Under the required rate the annual utility bill savings is reduced to $27 \%$. If the $\$ 200$ deposit is added to the first year's bill, the savings in the first year is reduced to only $1 \%$. The higher rate for auxiliary energy to solar buildings, and more significantly, the added $\$ 200$ service deposit make the solar alternative unattractive for residents of Columbia, Missouri.

In a 1915 case involving the refusal of a telephone utility to render service without an advance payment from the customer, the Supreme Court recognized the generally accepted rule that a regulation or policy requiring payment in advance or a fair deposit to secure payment for public utility services is reasonable [409]. The Arizona Supreme Court has held, however, that for a utility to enforce the requirement of a deposit against some of a utility's applicants but not against all constitutes improper discrimination [410]. The case involved an application for electric and water service by an applicant who purchased a lot within the city and tendered the standard $\$ 5$ service deposit, but was refused service unless he deposited $\$ 50$ to guarantee the building of a permanent residence upon the lot. 
TABLE 4-5. COMPARISON OF UTLITY BLLS FOR ELECTRICHEATED AND 70\% SOLAR-HEATED HOMES BASED ON COLUMBIA, MISSOURI, ELECTRIC SERVICE RATES

\begin{tabular}{|c|c|c|c|}
\hline \multirow[b]{2}{*}{ Month } & $\frac{\text { Electric-Heated }}{\text { Home Bill }}$ & \multicolumn{2}{|c|}{ 70\% Solar-Heated Home Bill } \\
\hline & Electric Heat Rate ${ }^{a}$ & Regular/Solar Rate R $^{\mathrm{b}}$ & Electric Heat Rate ${ }^{a}$ \\
\hline Jan & $\$ 111.08$ & $\$ 96.62$ & $\$ 78.10$ \\
\hline Feb & 83.85 & 56.47 & 49.04 \\
\hline Mar & 74.08 & 40.44 & 37.44 \\
\hline Apr & 64.06 & 36.59 & 34.75 \\
\hline May & 41.48 & 33.82 & 33.11 \\
\hline Jun & 40.09 & 33.82 & 33.82 \\
\hline Jul. & 33.82 & 33.82 & 33.82 \\
\hline Aug & 34.73 & 33.82 & 33.82 \\
\hline Sep & 51.23 & 33.82 & 33.82 \\
\hline Oct & 66.60 & 33.82 & 33.82 \\
\hline Nov & 82.14 & 57.48 & 49.77 \\
\hline Dec & 96.74 & 78.57 & 65.04 \\
\hline Totals & $\$ 779.95$ & $\$ 569.09$ & $\$ 516.35$ \\
\hline
\end{tabular}

As the regulation of rates charged by a municipal electric utility is not within the jurisdiction of the Missouri Public Service Commission [411], an investigation of the Columbia municipal charter or city ordinances pertaining to utility charges would be required, to asccrtain whether the $\$ 200$ deposit required from only solar customers is unduly discriminatory.

\subsection{RATE STRUCTURES AND SOLAR SYSTEM DESIGN}

One study examined the potential impacts of four different rate schedules upon utilities and solar commercialization [412]. The effect of rate structure inversion or flattening of traditional decling block rates would be to increase energy cost savings realized by solar users and thereby provide a marginal incentive for solar energy use. This incentive is likely to encourage broader application of solar energy but would not have an influenre. on an hourly variution of solar utilization [413]. The effect of rate structure inversion on the financial position of the utility is incapable of precise ascertainment but would depand heavily on the utility's individual operating characteristics [414].

A TOD rate structure would encourage a shift in consumption patterns from peak to intermediate- or off-peak periods and provide an incentive to use energy conserving technologies capable of displacing a portion of peak requirements [415]. Under this type of rate structure, solar-equipped facilities could be designed for the benefit of both the solar user and the electric utility by providing off-peak storage capacity. 'The sizing of storage capacity would be governed by the differential in rates between peak and off- 
peak periods. The economic impact of TOD rates upon the utility would depend upon its individual operating characteristics combined with the administrative, metering, and special control costs associated with this type of rate structure [416].

A third possibility is the establishment of special rates for solar users designed to encourage the use of off-peak power while discouraging peak demands [417]. In light of their promotional nature, PUC approval would require that these rates not be unduly discriminatory within or between classes of customers. Policy positions justifying the existence of lifeline structures might be raised in support of such special solar rates. As with TOD rate structures, a peak/off-peak differential in rates to solar users would require special metering and controls, and possibly additional administrative costs to the utility.

A demand charge for solar users was found to have only marginal value for optimal solar/utility design. While the individual customer would be encouraged to reduce his peak demand, this would not necessarily tend to reduce the peak capacity requirements for the utility [418]. Any rate structure developed for solar users should be given careful consideration with particular attention to the balance between the benefits derived from increased solar energy commercialization and the costs to both the utilities and nonsolar ratepayers [419].

In another study it was discovered that the type of rate structure imposed by an electric utility for auxiliary service significantly affects the cost-effective design of the solar system. For a southwestern summer peaking utility, a building having $30 \mathrm{~m}^{2}$ of collector area is most cost effective under a rate structure based on average accounting costs; under a rate structure based on marginal cost pricing, however, a building with $50 \mathrm{~m}^{2}$ of collector area is the most effective solar alternative [420].

For a solar building in Colorado Springs, imposition of a demand/energy rate for backup electricity for heating purposses is diseriminatory toward the solar user [42.1]. The solar building peak demand was fourd to occur during off-peak periods in elght of nine nonsummer months [422]. The effect of this discrimination is a financial barrier to the purchase of a solar heating system. In another investigation involving two eastern utilities, however, the demand/energy rate structure was not found to be discriminatory against solar users. The report concluded that demand and customer-related costs were identical for solar and conventional customers and that only energy-related costs are reduced by a solar system [423]. Therefore, any appropriate combination of demand and energy charges applied to all residential customers including solar and nonsolar was considered to be equitable.

Two studies found that under traditional rate structures based on average accounting costs, solar users are subsidiżed by other customers [424]. Wherc such rate structures exist and a revenue deficiency results from the widespread use of solar energy, electric utilities will be forced to increase the rates to solar users to recover the cost of service, causing adverse public reaction and retardation of the market penetration of solar technologies [425]. Such action is also inconsistent with the national goals of energy conservation and environmental protection. To ullow solar users to acquire backup energy under traditional residential declining block rates results in improper design of the solar collector and storage system to optimally reduce the utility's peak load [426]. One report appropriately summarized that:

[u]nder existing rate schedules there is no apparent incentive to optimize the sizing and design of SHAC [solar heating and cooling] or the passive 
system to benefit utilities and solar users alike. Under existing average cost pricing schemes, utility revenue from solar will be highly mismatched to the costs imposed by solar users. This is less likely the case under marginal cost pricing. Demand-energy charges (Hopkinson tariff) are inefficient because of poor relationship between the building peak and the utility peak. Whether these demand charges are more economically efficient than average cost pricing is dependent on weather conditions and building design. It is conceivable utility peaks may be spiked by demand charges to solar users. In none of the cases examined was marginal cost pricing found to be more discriminatory, or allocatively less efficient than average cost pricing. This, however, may not be the case for all utilities and requires individual analysis. [427]

Given that non-time-differentiated rates based on average accounting costs do not (1) adequately allocate costs to serve customers with unusual load patterns, such as residential air conditioning customers or solar heating customers, (2) promote energy conservation, and (3) discourage peak period consumption [428], TOD rate structures appear to be the appropriate solution to load factor conflicts involving electric utilities and solar system design [429]. Under non-time-differentiated rates that are volume dependent, a customer receives faulty signals which appear to penalize him even if he actually improves the system load factor [430]. One report stated that the major advantages of TOD rates are (1) an encouragement of economic allocation of resources at the expense of higher metering and billing costs, (2) a close relationship between costto-serve and prices charged for the service, (3) an equal applicability to both solar and nonsolar customers, and (4) encouragement of a shift of energy consumption from peak to intermediate- or off-peak periods [431]. In a Wisconsin case mandating TOD rates for Wisconsin Electric Power Company's 500 largest residential customers, the commission provided that in addition to the primary benefit of economic efficiency, time-differentiated rates based on marginal cost pricing are expected to produce nine derivative benefits:

(1) Cost minimization on the part of the utility is encouraged.

(2) Equity and fairness in the prices charged will be promoted.

(3) System utilization or load factors will be improved.

(4) Environmental damages or externalities will be reduced.

(5) Energy conservation may be improved, and for any specified level of end use electric energy requirements, the energy efficiency of supplying it will be increased.

(6) Earnings stability will be increased as net revenue replaces gross revenue requirements as a more importunt regulatory mechanism.

(7) Tariff stability will be achieved as pressures for rate increases are reduced.

(8) Consumer freedom of choice will be increased and ways to avoid inflationary rate increases nffered. 
(9) Contrasted with other rate reforms, namely inverted or all-equal flat rates, industrial and employment interests are protected and stimulated. [432]

The commission found that these nine derivative benefits of TOD rates based on marginal cost pricing were the regulatory equivalent of "icing on the cake." Economic efficiency by the use of marginal cost pricing as a basis for a TOD rate structure is supported by two grounds: (1) the scheme provides a signal to consumers of the resource allocation and cost consequences of their individual decisions, and (2) the scheme provides a signal to the utility of consumer demand and willingness to pay for the purpose of guiding utility invest ment decisions [433] .

From the foregoing, it may be concluded that where metering and associated administrative costs are not prohibitive, the most desirable rate structure for auxiliary service to solar users, from the standpoint of both the utility and the consumer, is a time-differentiated scheme based on marginal cost pricing. Under this form of rate structure, the solar user theoretically would not be subject to rate discrimination either in favor of or against his interests. Furthermore, the load factor conflict under traditional rate structures will not arise and proper signals are provided to consumers to purchase equipment designed for optimal off-peak auxillary energy usage. The results of TOD rates for solar auxiliaries are likely to (1) promote national goals of energy conservation and environmental protection, (2) eliminate barriers to solar market penetration that any traditional discriminatory rate structure once imposed, (3) encourage the shif ting of peak period energy usage to other periods, thereby promoting utility goals of improved system load factor and more efficient system operation, and (4) relieve the burden of subsidizing one class of nustomers by other ratepayers. 


\section{SECTION 5.0}

\section{IMPACT OF SOLAR SYSTEMS ON ELECTRIC UTIIITIES}

The National Science Foundation has identified a number of problem areas associated with the public utility and solar energy interface. Two problem areas identified as priorities for research are: (1) determining the impact of solar energy systems on public utilities, and (2) identifying the impact of various utility rate structures on the commercialization of solar energy [434]. Several investigations dealing with the utility and solar energy interface are currently underway or have been completed [435], including research, development, and demonstration projects investigating (1) the impact of utility pricing on solar systems, (2) the impact of solar systems on utilities, (3) the feasibility of solar-assisted off-peak heating and cooling systems, and (4) the performance of demonstration buildings equipped with solar water heating and space conditioning devices both uncontrolled and controlled for optimum utility compatibility.

\section{I FEDERALLY FUNDED STUDIES}

When evaluating the appropriateness of rate structures under which electricity is supplied for auxiliary purposes to solar-equipped buildings, the effects of these systems on an electric utility's load pattern must be considered, especially on the coincident peak demand and the load factor. The supply of auxiliary electricity to solar-equipped buildings does not necessarily always affect the utility's operating characteristics adversely, because potential benefits can also accrue. These potential benefits include (1) incremental utility fuel savings, (2) plant capacity displacement, and (3) more efficient management of utility loads [436]. These benefits depend upon the type and size of solar system and various utility characteristics such as customer mix, generation mix, and annual load trends. Also important are the incremental capacity costs and associated fuel costs incurred in supplying solar building auxiliary energy needs.

In its analysis of solar technologies, the Office of Technology Assessment (OTA) investigated the costs of providing backup power from an electric utility [437]. The costs of providing auxiliary service were found to be sensitive to the following four factors: (1) the cost of cquipment by region, available financing, and the local cost of fuel; (2) local climatic conditions and their correlation with the utility's peak demand; (3) the type of solar design including collector area and storage capacity; and (4) the number of solar buildings in the utility's service area [438]. A three-step method of cost determination was used in the analysis. First, a typical utility was fabricated by combining various demands typical for the city under investigation, and the cost of providing this base service was computed. Second, the cost of serving a new incremental portion of demands imposed by both nonsolar and solar buildings was computed. Third, the effective cost of providing backup to solar buildings was determined by comparing the figures contained in the second step [439]. Because all costs for meeting the incremental demands assumed new utility equipment and future capacity additions, the investigation is a comparison of utility's marginal costs in serving both nonsolar and solar buildings.

The results of the OTA investigation are summarized in Table 5-1. This table compares the cost per $\mathrm{kWh}$ of providing electricity to the solar building, to the cost of serving a similar building using an electric heat pump. For example, the cost to serve a solar home in Boston is $13 \%$ less than the cost to serve a nonsolar home equipped with a heat pump. An examination of Table 5-1 indicates in general that (1) electricity costs are lower for 
Table 5-1. THE FRACTIONAL DIFPERENCE BETWEEN THE UTHITY COSTS [ $\$ / k W h]$ REQUIRED TO PROVIDE BACKUP POWER TO THE SYSTEMS SHOWN AND THE COSTS TO PROVIDE POWER TO A RESIDENCE EQUIPPED WITH AN ELECTRIC HEAT PUMP ${ }^{\natural}$

[see note for explanation]

1. Single family house with gas heat, hot water, and air conditioning

Albuquerque

Boston

Fort Worth

Omaha

Single family house with gas heat and hot water, and central electric air conditioning

$0.2 \varepsilon$

0.15

3. Single family house with jaseboard heat, electric hot water and window air conditioning

$-0.14$

$-0.15$

4. Single family house with solar heat and hot water backed up with a heat pump ard electric hot water ${ }^{b}$

5. Single family house with extra insulation, electric hot weter, and heat pump with:

a. Photovoltaic system with no battery and no sale to the utility

battery and permitted

c. Photovoltaic system with battery and no sales to utility

$-0.30$

$-0.27$

0.01

a[OTA Report, supra note 3 , at 153].

${ }^{b}$ Compared with single family house with electric ho: water and heat pump.

${ }^{c}$ Compared with singel family house with extra insulation, electric hot water, and heat pump.

NOTE: let $\mathrm{C}_{\mathbf{r}}=$ Incremental utility costs resulting from adding 1,000 reference houses with heat pumps.

let $\mathrm{K}_{\mathrm{r}}=$ the incremental number of $\mathrm{kWh}$ generated when 1,000 reference houses with heat pumps are added to the utility.

let $C_{t}$ and $K_{t}$ be the equivalent quantities resulting from adding 1,000 houses with a different kind of energy equipment.

Then the fractional change illustrateid above is given as Follows:

$$
F=\frac{\left(C_{t} / K_{t}\right)-\left(C_{r} / K_{r}\right)}{\left(C_{r} / K_{r}\right)}
$$


houses using electric resistance heat, and are higher for houses using gas heat and electric air conditioning compared to a house using a heat pump; (2) a solar house costs the utility more per $\mathrm{kWh}$ than a conventional house using baseboard heat, but less than a house using gas heat and electric air conditioning; (3) depending upon the region, a photovoltaic-equipped house costs the utility less to serve than a house equipped with solar heating and hot water; and (4) the utility costs to provide backup power to a photovoltaic-equipped house are increased if sales of excess energy to the utility are permitted. Where off-peak storage can be utilized by both solar and nonsolar buildings, a reduction in utility costs to provide backup and conventional service is significant [440]. Table 5-2 illustrates the impact of off-peak storage on utility costs for both nonsolar and solar houses compared to a house using electric resistance space and water heating and window air conditioners. Utility costs are reduced by nearly $50 \%$ for electricity supplied to a nonsolar home capable of storage for heat, hot water, and cooling. Under the same off-peak storage design for a solar house, the reduction in utility costs amounts to nearly $40 \%$.

The nature of the conflict between solar applications and current utility operations was defined by the Energy Policy Project of the National Conference of State Legislatures:

The essential conflict between solar thermal applications and current utility operations arises from two basic sources:

(1) Reduction in net electric sales: any energy source which is utilized to displace electric sales exerts an adverse impact by reducing the utility's energy market-share. Similarly, energy conservation measures which reduce demand levels have the same effect. To the utility, these are clearly foregone sales opportunities and, hence, foregone profits.

(2) Reduction in load factor: to the extent utility pricing structures do not accurately reflect utility operating costs, lost sales may affect revenues differently than costs. This may result in lost profits (where the lost sale would luve yielded revenues in excess of its cost) or inereased profits (where the price of the lost sale was lower than its cost).

[A] solar thermal system which reduced total consumption of electric energy by a customer but did not affect the amount that customer demanded at the time of the system peak demand, could have the effect, conceptually, of requiring the utility to maintain generating capacity to serve the customer's peak demand while not allowing the utility to recover its total costs because the off-peak sales would be lost. Thus, the adverse consequences to the utility arise, in the first instance, from the failure of the utility's price structure to accurately reflect the utility's costs. They do not arise from any inherent, uncontrollable inconsistency in the basic technology or economics of either system. [441]

If it is assumed that backup systems will be used mainly during periods of extreme weather conditions when utilities, because of load sensitivity to weather, are experiencing peak demands with little or no usage during off-peak periods, widespread adoption of solar would exacerbate utility peak demands while reducing system load factors [442].

One study obscrved that the widespread application of solar systems is likely to have two primary effects on the financial positions of electric utilities: (1) reducing electric utility revenues when solar energy is being used, and (2) either increasing or decreasing 
Table 5-2. THE IMPACT OF OFF-PEAK STORAGE ON UTILITY COSTS

[f ractional increase or decrease in backup casts per $\mathrm{kWh}$-see notes] ${ }^{\mathrm{a}}$

\begin{tabular}{|c|c|c|c|c|}
\hline . & Albuquerque & Boston & Fort Worth & Omaha \\
\hline \multicolumn{5}{|l|}{ Nonsolar houses } \\
\hline - Off-peak storage for heat and hot water & -0.37 & -0.38 & -0.29 & -0.34 \\
\hline $\begin{array}{l}\text { Off-peak storage for heat, hot water, } \\
\text { and cooling }\end{array}$ & -0.47 & -0.45 & -0.48 & -0.44 \\
\hline $\begin{array}{l}\text { Houses with solar heating and hot water } \\
\text { - No off-peak storage }\end{array}$ & 0.03 & -0.11 & 0.12 & -0.06 \\
\hline - Off-peak storage for heat:ng and hot water & -0.11 & $-0 . £ 4$ & 0.003 & -0.21 \\
\hline $\begin{array}{l}\text { - Off-peak storage of heating, hot water, and } \\
\text { cooling }\end{array}$ & -0.03 & -0.35 & -0.32 & -0.36 \\
\hline
\end{tabular}

a [OTA Report, supra note 3, ct 157].

Notes: The reference house: is a single family house using electric resis:ance heating and hot water and window air conditioners. All solar houses generate on-y heating and hot water from solar energy.

Let $\mathrm{C}_{\mathrm{r}}=$ added utility costs resulting from the addition of 1,000 reference houses

$\mathrm{K}_{\mathrm{r}}=$ added $\mathrm{kWh}$ resulting from the addition of 1,000 ref arence houses.

$C_{t}=$ added utility costs res:lling from the addition of 1,000 test houses (type not $\in d$ in left column above).

$K_{t}=$ added utility costs resilting from the addition of $1: 000$ test houses

The fractional change ratio shown above is calculated as follows:

$$
F=\frac{\left(C_{t} / K_{t}\right)-\left(w_{r} / K_{r}\right)}{\left(C_{r} / K_{r}\right)}
$$


the electric utility's peak generating capacity, depending upon the type of load being displaced and the utilization pattern of the installed solar systems [443]. In a study of the projected effects of residential solar heating for a period from 1975 to 2000 on two eastern electric utilities, it was concluded that (1) a solar-heated residence is characterized by a load factor $40 \%$ to $50 \%$ lower than the load factor of a conventional electric resistance heating customer; (2) the peak electrical winter demand of a solar-heated home is virtually equal to and occurs at the same time as that of an electric resistance heated home in four of five years; (3) under rate structures that recover the cost of service through an energy charge alone, electric utilities will suffer revenue deficiencies from solar heating customers unless these customers are charged a different energy rate than the conventional heating customers; (4) the relatively slow rate of solar heating introduction will pose no critical systems or financial problems within the study period for the participating utilities; and (5) the thermal storage device contained in all solar heating systems could be used to decrease utility system demand peaks [444] .

Another study investigated the impacts of solar systems upon several utilities [445]. In the case of a southwestern summer-peaking utility, load was found to be highly weather sensitive with a strong correlation between temperature and system load [446]. Comparing conventional and solar residential buildings similarly equipped with absorption air conditioners, it was found that the solar building on peak days for the period 1969 to 1972 required auxiliary demand from $9 \%$ to $98 \%$ less (depending on collector sizes) than the electrical demand of the conventional building. Annual consumption for the conventional building was $38,216 \mathrm{kWh}$ with an absorption cooler, and $21,524 \mathrm{kWh}$ with a compresssion cooler. The solar building consumed $20,515 \mathrm{kWh}$ annually with $15 \mathrm{~m}^{2}$ of collector area, and only $147 \mathrm{kWh}$ with $66.9 \mathrm{~m}^{2}$ of collector area [447]. In the case of a winter-peaking utility, demands for auxiliary energy in the solar building ranged from $0 \%$ to $95 \%$ less than those for the conventional building. Annual electrical energy consumption for the conventional building in the winter-peaking utility was $34,565 \mathrm{kWh}$ with the use of an absorption cooler, and $25,688 \mathrm{kWh}$ with the use of a compression cooler. On the other hand, the solar building required $14,487 \mathrm{kWh}$ with $30 \mathrm{~m}^{2}$ of collector area and only $3,523 \mathrm{kWh}$ with $100 \mathrm{~m}^{2}$ of collector area [448]. Table 5-3 is a summary of the demand effects on various utilities by a solar building having $66.9 \mathrm{~m}^{2}$ of collector area relative to a conventional building. For both the summer- and winter-peaking utilities, under rates based on average accounting costs, service to the solar building for auxiliary purposes resulted in revenue deficiencies to the utility. The utility, under the existing rate scheme, would not recover the total cost to serve from solar customers [449]. It was concluded that:

[N] general statement can be made regarding the impact of SHAC [solar heating and cooling] upon the load curve of the electric utility industry. This analysis must be performed on an individual utility basis, since variations in the ambient weather conditions, load curves, and generation mixes of utilities will be the prime determinants in the magnitude of the impact. [450]

Taken together, computer simulation studies portray conflicting impressions of the effects of solar auxiliary demands on electric utilities. In two significant studies, storage charged by solar only was considered. Therefore, the auxiliary was tripped on upon demand, and once the solar storage was exhausted, the auxiliary acted as would the heating or cooling device in a conventional building contributing to peak period demand [451]. With a solar system capable of storage facility recharge by either solar or auxiliary energy, confining auxiliary recharge to off-peak or intermediate periods would reduce peak period demand. Such a system could limit a solar auxiliary's peak period demand to no more than two-thirds of the peak period demand for an all-electric heating system [452]. 
Table 5-3. RATO OF SOLAR DEMAND TO CONVENTIONAL DEMAND AT PEAK ${ }^{2}$

Residential Building I with a $66.9 \mathrm{~m}^{2}$ Collector $^{\mathrm{b}}$

\begin{tabular}{|c|c|c|c|c|c|c|}
\hline UTILITIES & $\begin{array}{l}\text { Wisconsin } \\
\text { Power and } \\
\text { Light }\end{array}$ & $\begin{array}{l}\text { New } \\
\text { England } \\
\text { Elect:ic } \\
\text { System } \\
\end{array}$ & $\begin{array}{l}\text { Georgia } \\
\text { Power }\end{array}$ & $\begin{array}{l}\text { Public } \\
\text { Service cf } \\
\text { New Mexico }\end{array}$ & $\begin{array}{l}\text { Arizona } \\
\text { Public } \\
\text { Service } \\
\end{array}$ & $\begin{array}{l}\text { Sacramento } \\
\text { Municipal } \\
\text { Ltility } \\
\text { Listrict } \\
\end{array}$ \\
\hline 1975 & .38 & .85 & .05 & .29 & 0.0 & $.23^{d}$ \\
\hline 1974 & .22 & .95 & .14 & $.53^{\mathrm{C}}$ & 0.0 & .29 \\
\hline 1973 & .78 & $.7 \varepsilon$ & .27 & .35 & 0.0 & 1.56 \\
\hline 1972 & $.79^{d}$ & 1.00 & .48 & $1.00^{\circ}$ & 0.0 & \\
\hline 1971 & .93 & . $0 \varepsilon$ & .97 & .28 & 0.0 & 0.0 \\
\hline 1970 & .94 & .1 .00 & .17 & .06 & 0.0 & 0.0 \\
\hline 1969 & 1.00 & 1.00 & .33 & 1.07 & $0.0^{\mathrm{d}}$ & 0.0 \\
\hline 1968 & .97 & $.57^{d}$ & $.12^{\mathrm{d}}$ & & 0.0 & .32 \\
\hline 1967 & .74 & 1.00 & .27 & & 0.0 & .22 \\
\hline 1966 & 1.00 & 1.00 & 2.68 & & 0.0 & .22 \\
\hline $\begin{array}{l}\text { Average of } \\
\text { Ratios } \\
\text { Weighted } \\
\text { Averages }\end{array}$ & $\begin{array}{l}.78 \\
.77\end{array}$ & $\begin{array}{l}.82 \\
.78\end{array}$ & $\begin{array}{r}.56 \\
.45\end{array}$ & $\begin{array}{r}.51 \\
.49\end{array}$ & $\begin{array}{l}0.0 \\
.00\end{array}$ & $\begin{array}{l}.32 \\
.32\end{array}$ \\
\hline
\end{tabular}

${ }^{\text {a }}$ [Utility Pricing/Solar Design, supre note 420 , at 109$]$.

b Solar building uses ajsorption cooler, conventional building uses compressica cooler, and both buildings use electric resistance heating.

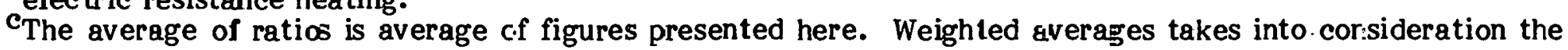
magnitude of each year and is the better representation of capacity effect.

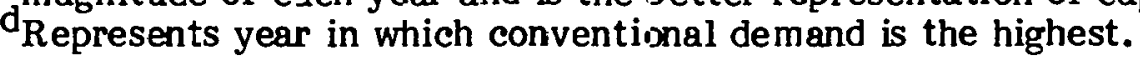




\subsection{ELECTRIC POWER RESEARCH INSTITUTE (EPRI) STUDIES}

From the computer simulation studies, it appears that to accurately determine the effects of solar buildings on an electric utility's load characteristic, actual solar building performance data including coincident peak demand, time of occurrence, energy consumption, insolation, weather characteristics, and other pertinent factors are required. Aware of the need for impact studies considering actual solar building performance data, the Electric Power Research Institute (EPRI) embarked on a \$2 million research program involving: (1) a two-year project to develop a computer model for predicting the effect of solar heating and cooling (SHAC) on utility systems, and (2) a three- to five-year project in which 10 experimental houses are being built to test different solar system configurations and validate the computer model [453]. Early in 1978, five houses were bding constructed in Wading River, Long Island, N.Y. and five houses were being constructed in Albuquerque, N.M. The houses range in size from $1,800 \mathrm{ft}^{2}$ to $2,000 \mathrm{ft}^{2}$ and are in the $\$ 65,000-\$ 80,000$ price range. Two electric utility companies are directly participating in the study-Long Island Lighting Co. and Public Service Co. of New Mexico. Heating and cooling system temperatures, flow rates, daily insolation, equipment performance, and energy use will be metered at each house.

Summary and final reports of Phase 1 of the project were available from EPRI in 1977. Phase 1 developed a methodology for relating solar building performance to utility generation, costs of supply, and weather characteristics; identified preferred systems for the participating utility; developed preliminary designs for the experimental solar systems; and developed instrumentation and test plans for the experiments [454].

In another EPRI-funded effort considering the interface of solar buildings with an electric utility, the full impact and cost to the Colorado Springs municipal electric utility and its customers (resulting from widespread use of seven types of heating systems) was determined [455]. Actual data from the solar-equipped Phoenix House was utilized in the study. The study concluded that the preferred system is a solar system with seasonal storage, utilizing an electric heat pump in series between the thermal load and thermal storage and between the thermal load and electric utility. It was recommended that the city adopt an incentive program to encourage preferred system use [456].

EPRI sponsored a computer simulation analysis of the impact of SHAC upon electric utilities that was completed in mid-1978. The objective of the investigation was to assess the impact of SHAC systems on electric utilities and define the requirements for the design of those systems having the most benefit to both the solar user and the utility. Volume 1 of the study provides the principal findings and a brief discussion of the methodology used in the study [457]. Details and results of the analysis of the change in utility demands due to SHAC implementation in the participating utilities service areas are provided in Volume 2 [458]. Volume 3 reviews the definition of reference buildings and SHAC systems [459], and Volume 4 details the costs of SHAC ownership and the economic impacts on the utilities [460]. Where resistive electric heating was displaced, direct solar, direct solar with load management, and solar-assisted heat pump systems found various preferred applications in the nine cities considered. Only a solar-assisted heat pump was preferred over a conventional heat pump, and only in two cities [46 l].

Probably the most beneficial information to consumers and utilities alike will be the results of EPRI's System Definition Study. Since the study will make use of actual solar house performance data, ratemakers should be able to design rate structures to accurately reflect the costs to serve solar customers in addition to promoting the use of "pref erred" solar systems. 


\section{SE尺r|*}




\section{SECTION 6.0}

\section{ELECTRIC RATE AND SERVICE DISCRIMINATION}

Significant concerns of solar users, the electric utility, and nonsolar ratepayers are whether rates can be legally designed to discriminate for or against solar users and whether electric utilities can refuse to provide backup service to solar users.

\subsection{RATE DISCRIMINATION}

It is a general rule that public utilities cannot unreasonably discriminate in rates charged to customers similarly situated, of the same class, or for the same service under like conditions [462]. Typically, only "unreasonable" differences in rates are prohibited [463], and differences in rates between customers are valid where there exists a reasonable basis for distinguishing them [464]. Where courts or state commissions have ruled on the issue of discrimination in utility rates, they have not made particularly clear what constitutes reasonable as opposed to unreasonable discrimination [465].

A victim of a discriminatory rate practice is likely to seek relief by challenging the practice under state antidiscrimination statutes, federal antidiscrimination statutes, and state and federal constitutions. The common law may also prohibit discrimination by public utilities. The Supreme Court of Texas, in City of Texarkana v. Wiggins, said:

The common-law rule that one engaged in rendering a service affected with a public interest or, more strictly, what has come to be known as a utility service, may not discriminate in charges or service as between persons similarly situated is of such long standing and is so well recognized that it needs no citation of authority to support it. The economic nature of the enterprise which renders this type of service is such that the courts have imposed upon it the duty to treat all alike unless there is some reasonable basis for a differentiation. Statutes have been enacted in almost every state making this common-law rule a statutory one. [466]

\subsubsection{State Antidiscrimination Law}

Because a major objective of utility rate regulation is the prevention of undue discrimination or unreasonable preferences, nearly every state has a statute prohibiting pricing practices that favor one customer over another [467]. New York's Public Service law requires that no electric corporation shall charge or receive from any other customer a greater or less compensation for electricity than it charges or receives from any other customer for providing like and contemporaneous service under substantially similar conditions [468]. The statute further states that no electric corporation shall grant any undue or unreasonable preference or advantage to any customer, or subject any customer to any undue or unreasonable prejudice or disadvantage in any respect whatsoever [469]. However,

Nothing in this chapter shall be taken to prohibit a gas corporation or electrical corporation from establishing classifications of service based upon the quantity used, the time when used, the purpose for which used, the duration of use or upon any other reasonable consideration, and providing schedules of just and reasonable graduated rates applicable thereto. [470] 
In addition, the New York commission has the power to require each electric corporation to formulate classifications of service based upon the quantity of electricity used, the time when used, the purpose for which used, the duration of use, and upon any other reasonable consideration [47 1].

A Supreme Court of New York held that utilities cannot choose their customers or discriminate between them by extending unreasonable conditions and preferences to some, but must serve all on the basis of faimess and equality, or be deemed in violation of the Public Service law [472]. In another New York case, a gas distributor sought a declaratory judgment decreeing that contracts offered by an electric corporation for electric lighting service at lower heating rates, provided the customers also heated their premises by electricity, were in violation of subdivisions 2 and 3 of section 65 of the Public Service law [473]. The court held that the plaintiff's allegations constituted a cause of action under the Public Service law and accepted jurisdiction without initial hearing on the issue by the Public Service Commission [474]. In I.efknwitz. y. Publie Service Commission [475], a temporary one-year subsidy offered by the commission to residential electric space heating customers at the expense of all other customers was challenged as being arbitrary, capricious, and discriminatory. The commission's action was in response to the drastic rise in utility fuel costs following the 1973 Arab nil embargo and numerous complaints by customers in this classification resulting from a corresponding increase in electricity rates. It was felt that all-electric customers, under the post embargo drastic rate increases, would suffer a disproportionate burden since they were induced to select electric heating by earlier favorable rates. The New York Supreme Court, Appellate Division, held that the subsidy ordered by the commission constituted an undue preference and advantage in violation of the Public Service law; and a finding that residential electric space heating customers were entitled to relief under the commission's order did not constitute a classification based upon a reasonable consideration [476]. The New York Court of Appeals affirmed the decision of the lower court stating that "[t] he Appellate Division correctly determined that the one-year rate adjustment ... was invalid as an undue preference and advantage . .." [477]. It further held that "[t]he basis offered by the commission that residential elertrir space heating customers would suffer a 'disproportionate' burden unless their rates were anjusterd and the offset of the adjustment borne by other classes of users was not reasonable" [478].

The Wisconsin antidiscrimination statute provides that if any public utility shall charge or receive from any customer a greater or less compensation for any service rendered than it charges or receives from any other customer for a like and contemporanenus service, such public utility shall be deemed guilty of unjust discrimination [479]. The statute further states that if any public utility shall give unreasonable preference or advantage to any customer or subject any customer to unreasonable prejudice or disadvantage, such public utility shall be deemed guilty of unjust discrimination, which is hereby prohibited [480]. As in New York, the Wisconsin commission has the authority to provide for a comprehensive classification of service for each public utility that may take into account the quantity used, the time and purpose of use, and any other reasonable consideration [48 1].

In 1912, the Supreme Court of Wisconsin held that a contract between a village and an electric utility, in which the utility agreed to supply free electricity to the village up to a specified amount, created an unjust discrimination in violation of the public utilities act [482]. The $W$ isconsin commission held that the application of three different rates to customers whose demand and conditions of service are similar is discriminatory [483]. The commission held in a later case that significant differences in the load characteristics of electric customers could result in a difference in the cost of service to each and justify separate classifications with different rates [484]. 
A Colorado statute states that no public utility shall, as to rates, grant any preference or advantage to any customer or subject any customer to prejudice or disadvantage; nor shall any public utility maintain any unreasonable difference as to rates either between localities or between any class of service [485]. As to classification, the Colorado commission held that classification of electric customers for ratemaking must be founded upon the cost to the utility of providing the various classes of service [486]. It was further held that characteristics including production cost, customer's cost, demand factor, load factor, and diversity factor must be taken into consideration in determining whether electric rates are discriminatory [487]. In a later decision, the commission held that classification of utility customers is proper where rate differences are based upon a reasonable or fair difference in conditions which logically justifies a different rate [488].

Most state antidiscrimination laws proscribe rate discrimination that is unreasonable, unjust, undue, or unlawful [489]. PUCs are given broad discretion over the determination of whether rates are unlawfully discriminatory [490]. A challenge of discrimination in rates generally must first be heard by the state's PUC [491], and a court will not substitute its judgment for that of the PUC on questions of fact unless it appears from the record that the PUC's findings are clearly unsupported by the evidence [492] Therefore, a solar user who feels he is a victim of a discriminatory rate practice, must first seek and exhaust his administrative remedies through the PUC before a court proceeding may be had [493]. Once in court, the solar user is required to bear the burden of proving that his rates are discriminatory [494]. In view of these procedural and corresponding costly requirements, it would be difficult for individual solar users to challenge a discriminatory rate practice.

A general principle emerging from the decisions is that rate differences for various classes of customers of electric utilities are permissible if based on reasonable considerations [495], such as differences in the cost of service [496] or other factors, including the quantity of electricity used and the time duration and purpose of use [497]. Conceivably solar customers with low load factors, variable demands, different costs to serve, and ability to use off-peak electricity, may be classified separately from standard residential or commercial customers. In one jurisdiction, however, utilities may not impose higher rates on solar users. In 1977, the Illino is legislature amended the state's public utility antidiscrimination statute [498] to include the following paragraphs:

No public utility providing electrical or gas service shall consider the use of solar energy by a customel as a basis for establishing higher rates or charges for any service or commodity sold to such customer; nor shall a public utility subject any customer utilizing solar energy to any other prejudice or disadvantage on account of such use.

This amendatory Act of 1977 shall cease to have any force or effect 5 years after its effective date. [499]

Whether commissions and courts will approve of rates that discriminate in favor of solar users, by considering such discrimination reasonable, may depend on the jurisdiction's view of promotional rates [500]. Despite the state's antidiscrimination statute, a New Jersey court in Rossi v. Garton held that a $\$ 150$ credit to electric space heating customers as a promotional effort was not unreasonably discriminatory [50 l]. The court interpreted the statute to prohibit only unjust discriminations and concluded that only arbitrary discriminations are unjust. The court stated that "[i]f the difference in rates is based upon a reasonable and fair difference in conditions which equitably and logically justify a different rate, it is not an unjust discrimination" [502] . 
Rossi was cited by the Supreme Court of Maine in Gifford v. Central Maine Power Co. [503]. In this case, promotional allowances were offered to encourage and promote increased use of electric energy by residential customers. The allowances were challenged by some of the utility's residential customers as being unlawful and unjustly discriminatory in violation of the state's antidiscrimination statute. The court cited testimony given before the commission that the utility had capacity available to serve any load, added on account of the promotional allowances, at only the incremental fuel cost involved. The court concluded that "the promotional allowances could be reasonably expected to provide ultimate benefits to every customer and were fairly shown not to be excessive, disproportionate, unreasonable or unjustly discriminatory within the meaning of the statute" [504]. The Supreme Court of Oklahoma similarly held in State v. Oklahoma Gas and Electric Co., that promotional practices reasonably calculated to improve the utility's load factor and benefit all consumers by reducing the cost of energy, are not unjustly discriminatory [505].

Some promotional activities of little value to the utility and its customers have been struck down as unduly discriminatory [506]. An attempt by an electric utility to waive the extra cost of underground residential distribution provided that the builder create a wholly electric community was held in violation of Maryland's antidiscrimination statute [507]. The Maryland commission ruled that the waiver provision resulted in undue discrimination between the company's customers, by imposing unequal charges on the same types of customers for the same service, in violation of the Public Service Commission Law [508]. The Supreme Court of Missouri held that an electric company that agreed to provide a builder with promotional allowances contingent upon homes being built utilizing electric heat was not permitted to fulfill that agreement in the face of a commission order to the contrary [509].

Because solar systems have the potential to reduce utility capacity expansion and fuel expenditures and thereby reduce costs to all customers, it could be argued that discrimination in favor of solar users is not unreasonable or unlawful. This form of benign discrimination produces indirect benefits to all ratepayers and is consistent with national policy goals of energy conservation and environmental protection. Commissions and courts have supported measures that conserve energy in the form of programs to finance the installation of insulation [510], and have prohibited end uses of energy that do not contribute to conservation [511]. Conceivably, a program that directly assists solar customers while indirectly benefitting other customers is likely to be found reasonable. The United States Circuit Court for the District of Columbia has ruled that a rate order can be upheld even though it contains certain provisions that, taken separately, had discriminatory aspects, provided that the rate as a whole demonstrated an overall balance of effects and purposes in furtherance of the publle interest [512].

\subsubsection{Federal Antidiscrimination Law}

A second possible approach for a solar user who feels he is a victim of a discriminatory practice imposed by a utility is to seek relief under federal antitrust laws [513]. Any discriminatory practice against solar users, including rate and service discrimination [514], may give rise to an action based on the antitrust laws. These laws, however, can also outlaw policies that provide special benefits to solar users.

The earliest antitrust statute is the Sherman Act of 1890 [515]. Section two of the act prohibits monopolization or attempts by persons or corporations to monopolize. In Otter Tail Power Co. v. United States [516], the Supreme Court ruled upon a section two [517] 
monopoly charge against an electric utility. Otter Tail, an investor-owned electric utility, refused to sell wholesale power and wheel power from another source to small communities seeking to establish municipal distribution systems. It was Otter Tail's contention that FPC regulation of wholesale sales, wheeling, and interconnection barred antitrust action. The Supreme Court held that Otter Tail was not immune to application of antitrust regulation, because the Federal Power Act provides no clear legislative intent to make the antitrust laws inapplicable to electric utilities [518]. It was further held that the actions of Otter Tail in refusing to sell at wholesale, or to wheel, constituted anticompetitive and monopolistic practices in violation of section two of the Sherman Act [519]. Under these principles, an electric utility's refusal to provide backup service to a solar user because of a desire to protect its monopoly position, would be anticompetitive and in violation of the Sherman Act.

In Cantor v. Detroit Edison Co. [520], the Supreme Court examined the relation between state regulatory authority and the antitrust laws. For several years, Detroit Edison followed a policy of supplying free light bulbs to its residential customers-a marketing practice approved as part of its rate structure by the Michigan Public Service Commission. A retail druggist and seller of light bulbs challenged the practice by arguing that Edison used its monopoly status to restrain competition in the sale of bulbs and thus violated the Sherman Act. Edison maintained that the state action exemption to application of the antitrust laws applied in light of the state commission's approval of the marketing practice. The lower federal courts held, on the authority of Parker v. Brown [521], that the commission's approval of the practice constituted state action and exempted the practice from federal antitrust laws [522]. The Supreme Court reversed, stating that "state authorization, approval, encouragement, or participation in restrictive private conduct confers no antitrust immunity" [523]. The court concluded that "neither Michigan's approval of the tariff filed by respondent, nor the fact that the lampexchange program may not be terminated until a new tariff is filed, is sufficient basis for implying an exemption from the federal antitrust laws for that program" [524]. Therefore, a commission-approved utility practice that discriminates either for or against solar users, does not have a state action exemption from the antitrust laws.

The state action exemption, as applied to municipally owned utilities, was considered by the Supreme Court in City of Lafayette, Louisiana v. Louisiana Power \& Light Co. [525]. Cities owning municipal electric utilities brought an action against a privately owned utility on the basis of violation of federal antitrust laws, and the private utility counterclaimed on the same basis. A decision by the District Court dismissing the counterclaim was reversed and remanded by the Court of Appeals [526]. In a fragmented opinion, the Supreme Court affirmed the decision of the Court of Appeals by rejecting an automatic immunity from federal antitrust laws for municipally owned utilities. The Court concluded that actions of state agencies or subdivisions are exempt by the Parker doctrine only to the extent that such actions are "engaged in as an act of government by the State as sovereign, or, by its subdivisions, pursuant to state policy to displace competition with regulation or monopoly public service" [527]. Under this principle, a municipality adopting discriminatory practices in the providing of utility services in furtherance of its own policies, may be subject to federal antitrust laws. Where it appears that a municipality has acted pursuant to the state's command, the state action exemption would apply [528].

Another portion of the federal antitrust laws, the Robinson-Patman Price Discrimination Act, prohibits price discrimination where the effect of such conduct is to substantially lessen competition or to tend to create a monopoly [529]. It declared illegal the practice of charging different prices to purchasers of commodities of like grade and quantity. A 
utility's use of rate discrimination to advance or retard the commercialization of solar energy may be in violation of this Act.

\subsubsection{Constitutional Law}

The United States Constitution may provide restraints on a utility's ability to discriminate for or against solar users. Under the fourteenth amendment, it is unconstitutional for any state to deprive any person of property without due process of law, or to deny to any person the equal protection of the laws [530]. Where utility companies are involved, an issue arises as to whether their practices are sufficiently state-connected for purposes of the fourteenth amendment. Discriminatory practices not attributable to the state do not fall within fourteenth amendment prohibitions [53 l].

The issue of whether an electric utility's service termination procedure constitutes sufficient state action was addressed in Jackson v. Metropolitan Edison Co. [532]. The termination procedure, which had for many years been inserted in the company's general tariffs submitted for approval to the PUC, was challenged under the Civil Rights Act of 1871 [533]. Petitioners alleged state action on the ground that the state PUC had authorized and approved the termination procedure. The Supreme Court expressly rejected this contention, stating that "[a]lthough the Commission did hold hearings on portions of Metropolitan's general tariff relating to a general rate increase, it never even considered the reinsertion of this provision in the newly filed general tariff" [534]. In the Court's view, since the provision had never been the subject of a hearing or other special scrutiny by the PUC, the limited review afforded was not sufficient to constitute state action. Noting that regulated utilities of ten are required by law to seek PUC approval for practices an unregulated business would be free to institute, the Court held that approval by the PUC of such a practice, where the commission did not put its weight on the side of the practice by ordering it, was not state action [535]. The state action test articulated by the Court was whether a "sufficiently close nexus" between the state and the challenged practices of the utility justified treating the practices as those of the state [536]. 'I'he fact that the company enjoyed at least a partial monopoly in the supply of electric service within its service area, resulting from regulation under state law, did not contribute to the close nexus required for state action [537]. It was concluded that the State of Pennsylvania was not "sufficiently connected" with the company's action in terminating petitioner's service so as to make this an action of the state for purposes of the fourteenth amendment [538].

Public Ütility Commission v. Pollak [539], an earlier Supreme Court decision, involved the issue of governmental action (similar in principle to state action). A public transit company in the District of Columbia installed loudspeakers in its buses and streetcars over which it piped music, commercials, and news. Passengers of the company claimed that the broadcasting violated their first and fif th amendment rights. The District of Columbia PUC concluded, after substantial investigation and public hearings, that radio service was not inconsistent with the public convenience and safety, and tended to improve the condition under which the public rode [540]. The Supreme Court held that a "sufficiently close relation" between the Federal Government and the radio broadcasting required consideration of the constitutional claims [541]. In its findings, the Court did not rely on the fact that the company operated a public utility nor that the company enjoyed a substantial monopoly in providing its service. Rather, its holding rested primarily on the fact that the PUC, pursuant to passenger protests, specifically ordered an investigation of the practice and held public hearings [542]. 
Under these cases, PUC approval of a discriminatory practice by a utility for or against solar users may be an insufficient nexus to constitute state action. In the absence of state action, constitutional challenges based upon the fourteenth amendment will fail. If a PUC initiates further involvement to the extent of ordering that the discriminatory practice be undertaken by the utility or conducting a specific investigation of the merits of the practice, however, it is likely that a sufficiently close nexus and state action exists.

Assuming that state action for a particular utility rate practice does exist, rate discrimination may constitute a denial to the solar customer of property without due process of law. Customers of an electric utility challenged the orders of a PUC increasing electric utility rates, as violating their fourteenth amendment rights by depriving them of life, liberty, and property without due process of law in Georgia Power Project v. Georgia Power Co. [543]. The basic issue was whether electric utility customers have property interests protected by the Constitution in the rates they pay for electric service. The United States District Court for the northern district of Georgia concluded that residential users of electricity do not have a property interest protected by the due process clause in the rates they pay for service [544]. In arriving at its decision, the court relied on the rule stated in Board of Regents v. Roth [545] that in order to have a property interest in a benefit, a person must have a legitimate claim of entitlement to it [546]. Noting that the challengers had a legitimate interest in the rate increase, the court stated that this interest was common to all affected ratepayers, whereas previous cases in which entitlements were found involved either individual claims or identifiable classes for whom a benefit was specifically intended [547]. In Georgia Power Co. v. Allied Chemical Corp., the Supreme Court of Georgia similarly held that electric utility consumers have no property right in the rates they pay for service [548].

Where an action is commenced challenging a discriminatory practice by a utility as denial of the equal protection of the laws, a rational basis test is generally applied. In an equal protection challenge to an electric utility rate increase, the Supreme Court of Georgia stated:

Because rate making is a legislative act, our test under an equal prolection analysis of this economic regulation matter is whether there was a rational basis for the differing rate treatment of the complaining industrial class vis-a-vis other classes, and the rate must be approved unless we find it to be without a rational basis. [549]

Utility credit rules were contested on an equal protection basis in Wood v. Public Utilities Commission [550], in which the California Supreme Court stated, "[i] $n$ the field of economic regulation equal protection ordinarily requires only that there be a reasonable relationship between the classifications drawn and the purpose for which they are made" [551]. From the standpoint of the solar user, an equal protection challenge is likely to fail since a rational basis exists for classifying him separately from other customers. It is also probable that a court would find that for a utility to classify solar customers separately is reasonably related to the objective of recovering their costs to serve.

\subsection{SERVICE DISCRIMINATION}

A public utility is under a primary duty to pmvide just, reasonable, and adequate service to all those within the territory covered by its franchise who desire the service it renders [552]. This duty does not allow a utility to choose to serve only those that it finds most 
profitable [553]. The obligation to provide safe and adequate service arises through the common law but may be expressed by statute [554] .

Any policy by a public utility, which results in a refusal to provide backup service to solar users, is likely to be a violation of the utility's common law or statutory duty to provide service. Such a policy may also violate state antidiscrimination statutes and federal antitrust laws. The fact that a solar device may reduce a utility's system load factor is not so significant to justify a utility in refusing auxiliary service.

Instances exist where a utility is not required to serve particular individuals, despite its duty to serve the public. The duty to serve is not absolute but is qualified by the intervention of circumstances not within the utility's control such as customer misuse of service, acts of God (tornadoes, floods, lightning, etc.) labor-management controversies, shortage of supply, and, in some cases, lack of financial resnurees [555]. Customer misuse justifying a deprivation of service includes permitting nonpatrons to use the service in violation of utility rules [556], and tampering with meters [557]. The right of a utility to discontinue or refuse to provide service on the grounds of a shortage in supply appears to be limited to emergency circumstances. For example, the Wisconsin commission allowed a hydroelectric utility company to curtail service in 1948 when, because of the war, it was unable to install additional generating capacity. It had suffered a drought, and shifting load to off-peak periods would not solve the problem [558]. In addition, it has been held that sales by consumers to others (in essence, customer competition) negate the duty to serve [559]. Where the providing of service is unusually expensive, utilities have been excused from doing so [560]. However, decisions have been rendered to the contrary [561]. It has been suggested that a utility may not refuse to provide backup service to solar customers unless it can demonstrate that in doing so, substantial harm to its existing customers would result [562]. As with the issue of rate discrimination, service discrimination cases are given individual consideration according to their own circumstances, with "reasonableness" as the basic test.

In light of the impending natural gas shortage, a policy that may he favnred by courts and rUC's is to give priority for new gas taps to solar consumers desiring such service for auxillary purposes. Such a plan would be confined to regions where gas is available to new customers. The plan would (1) contribute to energy conservation and environmontal protection, (2) provide an incentive for solar commercialization, and (3) be particularly beneficial to solar users who find the costs of nllxiliary electrio servico prohibitivc. States have taken measures to restrict gas to certain customers or prohibit its availability for uses inconsistent with conservation [563]. Granting priorities for gas taps to solar users could be implemented as a conservation program; legislation has been passed in several states authorizing the formulation of conservation programs [564]. 


\section{SECTION 7.0}

\section{EXISTING AND PROPOSED SOLAR AND WIND RATES}

In the National Economic Research Associates (NERA) Rate Structure Revision survey of late 1977, each PUC was asked what policy it has adopted to insure that electric rates do not discriminate against or discourage the use of solar, wind, or other small generation for supplemental power [565]. Most commissions replied that no policy existed dealing with rates for consumers utilizing alternative energy sources [566]. Many commissions, though, replied that solar rates were being studied or are under investigation in generic rate hearings [567]. As of early 1978, public utilities under PUC jurisdiction in Illinois, Kansas, Michigan, New Hampshire, New York, North Carolina, South Carolina, Utah, and Wisconsin had special solar rates [568].

Of the commissions having solar rates on file or policies affecting such rates, most favored the use of supplemental energy sources and maintained policies against discrimination. For example, the California commission believes that existing rates do not discriminate against users of solar energy, wind energy, or small electric generating facilities. It further believes that California is moving toward rates that will encourage utilities to purchase the excess power generated by the alternate energy sources [569]. In Florida, the commission exempted an electric utility's customers with less than $25 \mathrm{~kW}$ of demand from standby charges [570]. The stated policy of the Indiana commission is to "encourage supplemental generation of power" [571]. In Kansas, the commission has adopted a filing by one utility that would include customers with a solar heating system in applicable, lower, all-electric or space heating rates [572]. The Michigan commission has a special rate on file for auxiliary services to residential customers generating their own power, with the sale of excess power by the customer back to the utility at reasonable cost [573]. The Montana commission is encouraging the development of small supplemental hydro, solar, and wind generation. It opposes standby charges and considers these sources of power similar to gas in determining the eligibility for certain rates. Further, it encourages utilities to purchase excess power from these sources and is contemplating a generic hearing on the issue [574]. The New York commission has rates on file from various utilities pertaining to solar and windmill customers, and has ordered modifications to these rates to assure that they are not discriminatory. It has a general policy against rate discrimination. While interest in these special rates is small, the commission intends to refine the rates as needed [575]. The North Carolina commission was required that the provisions and requirements of residential rate structures be adjusted, so that customers utilizing alternative energy sources would not be disqualified from a lower rate (all-electric or water heating) for which they would otherwise be qualified [576]. Only one commission discourages the use of alternative energy sources; in Oklahoma, supplemental or auxiliary power cannot be installed without commission approval [577].

\section{I SOLAR RATES}

Orange and Rockland Utilities, Inc., in New York, maintains a rate applicable to residential service with solar-assisted electric water and space heating [578]. The rate is temporary and available on an experimental basis to the first 20 eligible applicants who use the company's electric service for single-family residential purposes, and whose entire space and water heating requirements are supplied through a combination of electric space and water heating facilities and solar energy collectors. Service under the 
solar rate must have commenced by 31 Dec 77 , and will terminate on 31 Dec 79 . To be eligible for service under this classification, a customer is required to agree to accept system modifications, where feasible, made at the expense of the company to improve customer load characteristics through the use of hot and cold storage and off-peak charging capabilities. The customers must also permit the company to use special equipment to measure their loads, to measure the solar energy collected, and to obtain any other data necessary to determine the operating characteristics of solar installations. The effect of the solar rate is to charge solar customers the luwest rutes accorded to residential users with electric space and water heating, during the period October through May [579]. During the remaining months, solar customers are charged normal rates [580]. Because water heating in the summer could be substantially performed by the solar unit, providing a water heating discount would subsidize general use and air conditioning [581]. Additionally, the commission ordered that the company meet with the staff to explore the feasibllity of modifying thie sului systems being installed in up to 2.0 homes, for the purpose of developing thermal storage capabilities beneficial to the company's electrical system [582]. Company representatives indicated that as of late summer 1978, only three customers were taking service under the solar rate [583].

Similarly, electric utilities in North Carolina, South Carolina, Illinois, and Utah provide certain discounts to solar users as are provided to electric space or water heating customers. Duke Power Co. in North Carolina provides electric service to customers in both North and South Carolina, offering an experimental all-electric/solar residential service rate [584] to residences, condominiums, mobile homes, or individually nieleied apartments where the energy required for all water heating, cooking, and environmental space conditioning is supplied by electricity or solar. The company has the right to install, monitor, and operate metering and control devices on the customer's solar and electrical equipment to determine the effect of solar collection on electric service demand and usage. Further qualifications are required pertaining to the performance of the auxiliary space and/or water heating devices and the building's insulation level. In effect, the solar rate provides to solar consumers the discount afforded to all-electric consumers [b85], over the generul residentiul service rate [506]. The company also off cre an experimental water heating-electric/solar residential service rate [587]. In addition to the same metering requirement as the solar space conditioning rate, the solar water heating rate also contains certain specifications regarding water heating capacity and performance. The solar water heating rate, in effect, provides solar customers the discount given to customers under the residential service water heating electric rate [588].

Both Commonwealth Edison Co. and Central Illinois Light Co. (Cilco), make available to their customers a temporary residential solar assisted electric space heating rate [589]. Edison's rate is available on an experimental basis to the first 100 applicants for service who use the company's electric service for residential purposes and whose entire space heating requirements are supplied through a combination of electric and solar space heating facilities. It is required that customers served under this rate permit the company to use special equipment to measure their loads, the solar energy collected, and to obtain any data necessary to ascertain the operating characteristics of the solar buildings served. The solar rate provides customers with the discount accorded to electric space heating customers [590] in other than summer months over the normal rate [591]. Cilco's solar rate is available on an experimental basis to the first 50 applicants for service who use the company's service for domestic purposes and whose entire space heating requirements are supplied through a combination of permanently installed space heating facilities and solar energy collectors. Unlike Edison's solar rate, Cilco's rate does not require the auxiliary system to be electrical. Under Cilco's solar rate, 
customers receive the electric space heating discount [592] over the general residential service rate [593].

Utah Power and Light Co. offers an experimental, residential, all-electric, with solarassisted hot water heating rate to four customers who are participating in the company's solar augmented domestic water heating study program to evaluate solar energy's possible contribution to energy conservation and its effects upon residential load characteristics [594]. The rate applies to electric service for all residential purposes when the customer uses electric energy for requirements, including but not limited to lighting, cooking, appliance operation, air conditioning, and space heating; except that water heating will be supplied through a combination of electric water heating equipment and solar energy collectors providing supplemental water heating through heat exchangers. It is also required that the water and space heating equipment meet certain specifications. The charges under the solar rate are identical to the charges provided under the company's all-electric residential service rate [595], resulting in a reduction in rates over the general residential service rate [596] after $60 \mathrm{kWh}$ of consumption.

Electric utilities in New Hampshire, Wisconsin, Michigan, and Kansas, as well as offering solar customers an all-electric discount, maintain rates for providing off-peak and controlled electric service. Public Service Co. of New Hampshire has entered into a special contract with Total Environmental Action, Inc., to provide off-peak electricity for use as auxiliary energy in a solar heated home [597]. The special off-peak solar contract rate is lower (energy charge) than the charges for the all-electric space heating rate [598], but higher than the rate for controlled water heating service [599]. Under the contract, the solar home is equipped with a special electric hydronic thermal storage device, and certain specifications regarding the electric water heating device and the building's total heat loss must be achieved. The company has the right to install special metering equipment and recording devices to collect data for its load research program. Service for the remaining needs of the dwelling is metered separately and provided under the rates for which the customer qualifies.

Wisconsin Power and Light Co. maintains a supplemental energy off-peak service rate for 100 customers who agree to use off-peak service, and who have maximum monthly demands of less than $75 \mathrm{~kW}$ [600]. The purpose of the rate is to (1) encourage the development of supplemental energy sources that will reduce the consumption of typical fuels, and (2) provide an incentive to use energy during off-peak hours. Supplemental energy sources do not include natural gas, propane, electricity, fuel oil, and coal. Electricity purchased under this rate may be used to furnish storage for space heating and cooling or other devices, provided that the off-peak installation will use energy only during the designated off-peak hours. An active auxiliary energy system that provides at least $5 \%$ of the customer's total heating or cooling requirements must be used during the on-peak hours. Where the rate is used for heat storage, the storage facility must be large enough to store 14 hours of the hourly Btu loss of the building, and must provide enough heating elements to heat the building during the off-peak period. The company will meter on-peak usage and off-peak devices separately. It appears that only heating elements can be connected to the off-peak circuit, and fans, motors, and blowers would be connected to the general service circuit. The savings realized would be that provided under the off-peak energy charge compared to the general service rate [601]; however, this savings might be negated by the higher on-peak charge.

Rates for off-peak service designed to be controlled by the company are offered by Kansas Gas and Electric Co. (KG\&E), Wisconsin Public Service Corp. (WPS), and Detroit Edison Co. KG\&E's rate is an experimental off-peak storage rider limited to 200 
customers [602]. The rate is applicable to electric service for storage equipment used in space heating, cooling, and water heating normally supplied from solar sources electrically separated from the customer's normal usage. Service is controlled and available only between $10 \mathrm{p} . \mathrm{m}$. and $11 \mathrm{a} . \mathrm{m}$. every day of the year. The circuit supplying this service is in conduit, separately metered, with a company-approved load interrupting device. The savings ar ise from the difference between this rate and the residential total electric rate [603]. The WPS rate is available to the first 100 customers that enter into contracts with the company for service to storage-type space heating and/or space cooling systems in single-family residential dwellings [604]. Total customer load served under this rate is to be between $4.5 \mathrm{~kW}$ and $100 \mathrm{~kW}$. The service provided under this rate is separately metered, with control provided by a time-regulating device installed by the company. A solar user under this rate would suffer an added fixed charge, but enjoy a savings in energy charges for controlled service provided to his auxiliary system compared to the company's residential service rate [605]. Detrolt Edisun's experinitental solar-assisted water heating service rate is avallable to the first 500 customers taking service under the company's Dl-D4 schedule designations, who desire controlled water heating service to a solar-assisted electric water heater [606]. The company must approve the design and method of installation of the electric hot water auxiliary. The customer must permit the company to install recording meters and instruments necessary to determine the patterns of solar-assisted electric water heaters. Service is to be controlled by a timer or other monitoring device, but control of service is not to exceed four hours per day. The solar customer who takes water heating service under this rate is faced with a second service charge but a reduced energy charge compared to the company's residential electric space heating rate [607]. In its review of Edison's solar rate proposal, the Michigan commission stated that the solar rate contained the same charges as the company's controlled water heating service rate D5, option 1, and would not increase costs to any of Edison's existing customers [608]. 'The commission found that Edison's proposal to conduct a study of solar-assisted electric water heating and to offer a rate for such service was just, reasonable, and in the public interest, and therefore should be approved [609].

\subsection{THE COLORADO CONTROVERSY REVISITED}

The Colorado PUC [610] ordered a proposed mandatory demand/energy rate for allelectric and solar customers to be provided as optional, and left issues regarding separate rates for solar customers to be considered in the ongoing generic hearings [611]. In the generic hearings, Public Service Co. of Colorado (PSCo) proposed a residential solar service demand/energy rate [612]. The appropriateness of the PSCo proposed rate and a modification to the demand/energy rate for solar customers was investigated by the Colorado Office of Energy Conservation [613] .

PSCo's proposed residential solar service demand/energy rate is designed to be applicable only to residential service where solar energy is the principal source of heat. The rate is not applicable for electric service as the principal source of heat. The solar rate was developed from the residential demand service rate [614] by maintaining the same customer and energy charges but reducing the demand charges by 50\% [615]. Special conditions required to qualify for service under the solar rate are as follows: (1) the solar energy system must be designed to provide a minimum of $60 \%$ of the space heating requirements for the building and must be equipped with adequate storage facilities; (2) service under this rate is available only when the energy is used to supplement solar storage facilities, that is, electric space heating other than that supplying heat directly to the storage facility will not be permitted; (3) service under this rate for supplementing 
solar storage will be available only between 10 p.m. and 8 a.m. through a timeclock approved by the company and supplied by the customer; and (4) all wiring between the timeclock and the supplemental heating equipment served under this rate shall be placed in sealed conduit.

The effect of PSCo's proposed solar rate on solar system economics can be deter mined by the following analysis. Table 7-1 illustrates the electrical power requirements for a single-family all-electric home and $70 \%$ solar-heated home in Denver. Based on this data, the monthly utility bills were calculated for the $70 \%$ solar-heated home under the proposed solar rate, and are compared in Table 7-1 to the all-electric home monthly bills that would result under rates effective during the fall of 1978. It was assumed that the $70 \%$ solar heated home fully qualified under the requirements listed by PSCo for the residential solar service rate.

Table 7-1 indicates that the $70 \%$ solar-heated home under the proposed solar rate yields a savings of $44 \%$ on the annual electric utility bill of an all-electric home served under the demand/energy rate $(\mathrm{RD}-1)$. The savings increases to $54 \%$ if the all-electric home is served under the all-electric declining block rate ( $\mathrm{RH}-1)$. In comparing utility bill savings for only the $70 \%$ solar home served under existing rates and the proposed solar rate, a savings of $33 \%$ is realized from the proposed solar rate (RDS) compared to the demand/energy rate ( $R D-1)$. The proposed solar rate results in an annual utility bill savings of $29 \%$ compared to the all-electric declining block rate ( $\mathrm{RH}-1$ ).

It can be seen that PSCo's proposed solar rate would result in a significant increase (from $15 \%$ to $44 \%$ ) in the annual savings realized by a $70 \%$ solar heated home, compared with an all-electric home served under the demand/energy rate. The increase in savings (from $35 \%$ to $54 \%$ ) is also significant when comparing the $70 \%$ solar heated home's bill under the proposed rate to the all-electric home's annual bill under the all-electric declining block rate. However, the requirements of qualification for the proposed solar rate are stringent, particularly since the storage facility and auxiliary system must be designed for off-peak recharge only, and no auxiliary heating service can be supplied on-peak. This requirement, however, promotes the objective of solar system designs compatible with and favorable to electric utility systems. It is possible that solar systems incapable of storage recharge by auxiliary sources could require predominantly off-peak power as a backup once the solar charged storage has been depleted. Unfortunately, these solar systems, while not necessarily detrimental to the utility's load factor, would be unable to qualify for service under the proposed solar rate. In this respect, the rate is inefficient. In view of the significant savings that could be obtained from service under the proposed solar rate, PUC approval and PSCo's implementation of the rate would remove a potential barrier to the commercialization of solar energy in Colorado for those systems able to qualify.

The investigation of solar rates conducted by the Colorado Office of Energy Conservation recognized the advantages of basing rates on marginal cost pricing-particularly to the solar customer who would have the potential to realize not only fuel savings but also capacity savings [616]. A three-part rate incorporating separate demand, energy, and customer cost components would best reflect the marginal costs of providing service [617]. Rather than adjusting demand and energy charges according to time of use to reflect the differing utility costs of providing service at peak and off-peak periods, the investigation indicated that demand costs could vary according to the particular solar system served [618]. The highest capacity charge for solar users was assigned to solar systems having no storage capacity, and the lowest charge to systems capable of offpeak auxiliary recharge and utility-controlled interruption. Between the two extremes 
Table 7-1. ELECTRICAL POWER REQUIREMENTS FOR AN

ALL-ELECTRIC HOME AND A 70\% SOLARHEATED HOME IN DENVER AND COMPARISON

OF ELECTRIC UTHLTY BILLS FOR ALLELECTRIC AND 70\% SOLAR-HEATED HOMES BASED ON PSCO'S PROPOSED RESIDENTIAL SOLAR SERVICE RA'TE

\begin{tabular}{|c|c|c|c|c|}
\hline \multirow[b]{2}{*}{ MONTH } & \multicolumn{2}{|c|}{$\begin{array}{l}\text { All-Electric Home } \\
\text { Power Requirements }\end{array}$} & \multicolumn{2}{|c|}{$\begin{array}{l}\text { Solar-Equipped Home } \\
\text { Power Requirements }\end{array}$} \\
\hline & $\begin{array}{r}\text { Energy } \\
(\mathrm{kWh}) \\
\end{array}$ & $\begin{array}{c}\text { Demand } \\
(\mathrm{kW})\end{array}$ & $\begin{array}{r}\text { Energy } \\
(\mathrm{kWh}) \\
\end{array}$ & $\begin{array}{c}\text { Demand } \\
(\mathrm{kW})\end{array}$ \\
\hline Jan & 4,643 & 15.0 & 3,060 & 15.0 \\
\hline Feb & 3,336 & 12.7 & 1,665 & 12.7 \\
\hline Mar & 2,867 & 12.3 & 1,108 & 12.3 \\
\hline Apr & 2,386 & 10.5 & 979 & 10.5 \\
\hline May & 1,302 & 10.0 & 900 & 10.0 \\
\hline Jun & 1,096 & 10.0 & 900 & 10.0 \\
\hline Jul & 000 & 10.0 & 000 & 10.0 \\
\hline Aug & 926 & 10.0 & 900 & 10.0 \\
\hline Sep & 1,483 & 10.0 & 900 & 10.0 \\
\hline Oet & 2,017 & 10.0 & 300 & 10.0 \\
\hline Nov & 3,254 & 12.3 & 1,700 & 12.3 \\
\hline Dec & 3,957 & 12.4 & 2,433 & 12.4 \\
\hline TOTALS & 28,167 & & 16,345 & \\
\hline
\end{tabular}

All-Electric Home bill

\begin{tabular}{|c|c|c|c|c|}
\hline \multirow[b]{2}{*}{ Month } & \\
\hline & $R D-1^{b}$ & & $\mathrm{RH}_{-1} \mathrm{c}$ & $R-1^{d}$ \\
\hline Jan & $\$ 98.78$ & $\$$ & 142.40 & $\$ 123.70$ \\
\hline Feb & 78.33 & & 106.17 & 92.22 \\
\hline Mar & 72.36 & & 93.17 & 80.92 \\
\hline Apr & 61.78 & & 79.84 & 69.33 \\
\hline May & 49.33 & & 49.79 & 43.22 \\
\hline Jun & 47.27 & & 44.08 & 38.26 \\
\hline Jul & 45.31 & & 37.43 & 32.48 \\
\hline Aug & 45.57 & & 38.46 & 33.38 \\
\hline Sep & 51.14 & & 54.81 & 47.58 \\
\hline Oct & 56.49 & & 69.61 & 60.44 \\
\hline Nov & 76.23 & & 103.90 & 90.24 \\
\hline Dec & 83.59 & & 123.39 & 107.18 \\
\hline TOTALS & $\$ 766.18$ & & $\$ 943.05$ & $\$ 818.95$ \\
\hline
\end{tabular}

70\% Snlar Home Blll

\begin{tabular}{|c|c|c|}
\hline$R D-1^{b}$ & $\mathrm{RH}^{-\mathrm{I}^{\mathrm{c}}}$ & $\mathrm{RDS}^{\mathrm{e}}$ \\
\hline$\$ 82.93$ & $\$ 98.52$ & $\$ 58.93$ \\
\hline 61.61 & 59.85 & 41.29 \\
\hline 54.75 & 44.41 & 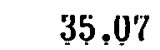 \\
\hline 47.70 & 40.58 & 30.90 \\
\hline 45.31 & 37.43 & 29.31 \\
\hline 45.31 & 37.43 & 29.31 \\
\hline 45.31 & 37.43 & 29.31 \\
\hline 45.31 & 37.43 & 29.31 \\
\hline 45.31 & 37.43 & 29.31 \\
\hline 45.31 & 37.43 & 29.31 \\
\hline 60.68 & 60.82 & 41.00 \\
\hline 68.33 & 81.14 & 48.49 \\
\hline ס & 609.90 & 431.54 \\
\hline
\end{tabular}

${ }^{\text {A}}$ From Table 4-1

b Demand/Energy Rate

All-Electric Declining Block Rate

$\mathrm{d}_{\text {General Residential Declining Block Rate }}$

eroposed Solar Residential Demand/Energy Rate 
were varying capacity charges depending upon the type of auxiliary system and storage capacity. The rate structure, because of its varying capacity charges with the level of solar system sophistication, was concluded to be administratively unworkable [619].

\subsection{WIND RATES}

Providing auxiliary service to customers (small power producers) utilizing wind power, photovoltaic, or other electricity-producing systems, involves issues in addition to the load factor conflict of solar technologies. From an electric utility standpoint, the load factor of a small power producer will not be high, as the systems are expected to result in minimal auxiliary energy use with intermittent capacity demands depending upon weather conditions. In addition to the rates charged for auxiliary service to decentralized electricity producing systems, concerns of the small power producer include (1) whether an electric utility can refuse to purchase any excess electric energy the small power producer may wish to generate back into the grid, and (2) if not, at what rate shall the utility purchase such power.

A 1975 George Washington University study found that most utilities prohibit reverse power flows back into the utility grid where auxiliary service is provided to a self-supply customer [620]. Because this practice would effectively deprive the nation of utilizable electricity when depletable resource conservation is a major national goal, consumers, PUCs, and legislatures have responed in a manner favorable to the small power producer.

As part of a rehabilitation of a tenement in New York City, a solar system for water heating and a $2 \mathrm{~kW}$ wind power generator planned to supply the collector system circulating pumps and lighting loads for the building's basement and hallways, were installed [621]. Negotiations began between Consolidated Edison Co. (Con. Ed.) and the Energy Task Force involved in the project regarding the conditions of service to the windmill-equipped facility. Con. Ed. was unwilling to allow reverse flow, being concerned about (1) the windmill's effect on transformers and computerized controls, and (2) possible hazards to line workers. The New York commission ruled on the issues of minimum charges per month, buy-back rates, a company liability indemnification provision, and other special provisions Con. Ed. proposed in the rate for windmill customers. The ultimate result was a revised schedule for electricity service under Servioe Classification No. 2.

Service Classification No. 2, General-Small, is applicable to customers who use the company's electric service for light, heat, and power where the requirements do not exceed $10 \mathrm{~kW}$ [622]. The rate contains an energy charge plus special provisions, applicable to customers who desire to operate a wind power generator in parallel with the company's system. Service to windmill customers under this rate is provided on an experimental basis to the first 25 applicants who qualify not later than 31 Dec 78 . Service is to continue to $1 \mathrm{Dec} 80$. In order to obtain service under this rate, applicants are required to submit a request for service to the company, listing the performance and safety features of the wind power generator [623]. This request must be approved in writing by an authorized company representative before service under this rate will commence. For windmill customers, the minimum monthly charge is increased proportionally to the windmill's capacity in $\mathrm{kW}$. An additional meter charge is assessed for the use of a meter to measure reverse flow, and the company will credit the customer its average cost of fuel per $\mathrm{kWh}$ (approximately $\$ 0.025$ per $\mathrm{kWh}$ ) for reverse flow electric energy. It is also provided that the company may install on the customer's premises any equipment needed to measure data necessary for determining the operating characteristics of a windmill served under this rate. The indemnification clause which provided 
that "[e] ach customer shall agree in writing to hold the Company harmless and indemnify it for any damages or injury in any way resulting from the installation or operation of his equipment" [624] was deleted from the final tariff. Otherwise, windmill operators would probably have needed to purchase liability insurance for their units-another cost disincentive to windmill operation.

The Energy Task Force commented that a minimum monthly charge of $\$ 4.96$ plus $\$ 6.80$ per $\mathrm{kW}$ of windmill capacity, acts as a disincentlve fol customers to install larger capacity units. It was suggested that the capacity charge be based upon the capacity of the load served by auxiliary energy when the windmill is not in operation. It should be pointed out that the customer credit for reverse flow power includes only an energy credit and no capacity credit. A capacity credit would provide more incentive to utilize windmill devices in parallel operation with the utility's system.

Central Hudson Gas and Electric Corp. in New York also filed revisions to its tariff on 4 Aug 77 , to establish additional charges and credits to residential Service Classification No, 1, fnr service. to windmills operated in parallel with its system [625]. The rate applies to electric service in single-family dwellings or apartments in multifamily dwellings. This rate also requires additional demand and metering charges for service to windmills. A credit is provided for energy generated back to the company equal to the average company cost of fuel per $\mathrm{kWh}$. No limitations are imposed on the capacity size of the windmill or upon the number of customers that may obtain service under the rate.

Southern California Edison Co. maintains experimental parallel generation rate schedules for domestic [626] and general [627] applications. The rates were instituted primarily to encourage limited cogeneration by utility customers and to give the utility experience with parallel operation by small power producers. The domestic purullel geileration rate is applicable to domestic service (lighting, heating, cooling, and power in a single-family accommodation) where a part or all of the electrical requirements of the customer can be supplied by a source other than the company and where a source is connected for parallel operation. Customer sources may irulude, but are not limited to, windmills, waterwheels, solar conversion, tidal action, and geothermal devices. The general parallel generation rate is applicable to single- and three-phase service, including lighting and power. The rates are temporary and will terminate after three years. The company will furnish and own all meters necessary for billing purposes and has the right to require the customer, as electrical operation conditions warrant, to limit the production of electrical energy from the parallel generating facility to an amount no greater than the load at the customer's premises. It is the responsibility of the customer to furnish, operate, and maintain relays, breakers, automatic synchronizer, and other control and protective apparatus designated by the company for suitable operation of the generator in parallel with the company's system. In addition, the company will install a disconnecting device near the meters.

Unlike the New York companies, Southern California Edison makes use of a "net energy charge" when crediting the small power producer for energy generated back to the company. Net energy is defined as energy supplied by the company, less energy generated by the customer and fed back into the company's system. This approach favors the small power producer because any capacity costs lumped into the energy charges will be saved, in addition to fuel cost savings, upon reverse power flows. In New York, only fuel savings and not capacity savings were credited to the windmill operators. The effect of Southern California Edison's rates is to encourage parallel generation operation, by giving to small power producers all potential savings the utility realizes from their excess generation. 
California enacted legislation in 1976 encouraging the development of new sources of natural gas and electricity [628]. The California legislative findings and declaration provide:

The Legislature hereby finds and declares that in order to promote the more rapid development of new sources of natural gas and electric energy, to maintain the economic vitality of the state through the continuing production of goods and the employment of its people, and to promote the efficient utilization and distribution of energy, it is desirable and necessary to encourage private energy producers to competitively develop independent sources of natural gas and electric energy not otherwise available to California consumers served by public utilities, to require the transmission by public utilities of such energy for private energy producers under certain conditions, and remove unnecessary barriers to energy transactions involving private energy producers. [629]

If this applies to electric utility rate and service policies toward small power producers who generate strictly for their own purposes, small power producers satisfying the private use requirement, hindered by an electric utility's rate and service policies, would have state policy favorable to their cause.

Within the California statute, "private energy producer" includes every person, corporation, city, county, district, and public agency of the state generating or producing electricity for energy, not generated from conventional sources or natural gas, solely for his or its own use or the use of his tenants and not for sale to others [630]. Where the private energy producer's generating facilities are distant from the load to be served, the state commission has the power to order interconnection between the private energy producer's source and the public utility's system, for the purposes of intrastate transmission of the energy [631]. Before such an interconnection can be ordered, the commission must find that (1) no uncompensated burden will be placed upon the utility furnishing the transmission service; (2) furnishing the transmission service will not result in any added costs for tho cuotomar of the utility; and (3) the fuclllles wlll be used to transmit power from other than a conventional power source for generating electricity [632]. The commission further has discretion to prescribe such reasonable terms, conditions, and requirements as it deems appropriate. Clearly, wind power, photovoltaic, and solar thermal clcctricity generating systems could fall within application of the statute potentially benefitting a qualifying small power producer. 


\section{SERI}




\section{SECTION 8.0}

\section{THE NATIONAL ENERGY ACT AND ELECTRIC UTILITY RATEMAKING}

The National Energy Act (NEA) [633] is comprised of five acts addressing utility rate reform [634], energy taxes [635], energy conservation [636], coal conservation [637], and natural gas policies [638]. Certain sections of the Public Utility Regulatory Policies Act of 1978 (the Act) [639], deal specifically with electric utility ratemaking, including policies or standards to be considered by PUCs regarding ratemaking practices, and provisions applying to small power producers encompassing ratemaking policies, parallel operation policies, and exemption from the Federal Power Act.

The purposes of the regulatory policies title of the Act are to encourage (1) conservation of energy supplied by electric utilities, (2) efficient use of resources and facilities by electric utilities, and (3) equitable rates to electric consumers [640]. The first purpose is to foster conservation by the ultimate end-users of electricity. The second purpose is directed at optimization of the efficiency of use of facilities and resources by electric utilities. The second purpose includes the use of rate reform to conserve energy resources. Where rate reform is initiated for this reason, however, rates must continue to be equitable to consumers [641].

Electric utilities having retail sales of more than 500 million $\mathrm{kWh}$ in a baseline year are subject to the provisions of this title of the Act. The baseline year is two calendar years before the year in question [642]. Differences in coverage of the Act between PUC regulated and nonregulated (other than state regulated) utilities are generally set out in specific sections.

Each PUC, on a utility-by-utility basis, and each nonregulated utility must consider certain federal ratemaking standards [643]. Such consideration is to begin by 9 Nov 80 and is to focus on whether or not it is appropriate to implement the standards in order to carry out the purposes of the Act [644]. The purposes are to supplement rather than supplant state law [645]. Thus, a PUC or nonregulated utility may determine that the standards are not appropriate. Where state authority is insufficient to permit implementation of the standards by each PUC or nonregulated utility, the puposes of the Act are deemed to provide such authority [646]. The requirement that the standards be "considered" is consistent with the Senate's proposal of the Act [647]. Under the House [648] and President's [649] proposals, the standards would have been mandatory.

The Act requires that consideration of the standards be made after adequate notice and hearing in accordance with state law. The Act further requires that the determination be (1) in writing, (2) based upon evidence presented at and findings of the hearing, and (3) available to the public [650].

Federal standards established by the Act address cost of service, declining block rates, time-of-day (TOD) rates, seasonal rates, interruptible rates, and load management techniques [65l]. Under the first standard, rates charged by electric utilities to each customer class shall be designed, to the maximum extent possible, to reflect the costsof -service to that class [652], and should identify differences in cost incurrence attributable to differences in customer, demand, and energy charges as well as differences in daily and seasonal time of use [653].

The second standard prohibits the use of a declining block rate structure for the energy component of a rate, unless the utility can demonstrate that energy costs decrease as 
consumption increases [654]. Under the third and fourth standards, rates charged to each class of customer shall be on TOD and seasonal bases that reflect the costs of providing services at different times of the day and seasons of the year [655]. The TOD standard is not required where rates so based would not be cost-effective. A TOD rate structure is considered cost-effective if the long-run benefits of the rate to the utility and its customers are likely to exceed the metering costs and other costs associated with use of the rate $[656]$.

Utilities are required to offer each industrial and commercial customer an interruptible rate under standard five, that reflects the cost of providing interruptible electric service [657]. The sixth standard requires each utility to offer to its customers such load management techniques as the PUC or nonregulated utility has determinded will (1) be reliable, (2) provide useful energy or capacity management advantages to the utility, and (3) be cost effective [658]. Load management techniques are deemed to be costeffective if they reduce maximum kilowatt demand on the utility and the longrun cost savings to the utility exceed the long-run cost of implementation [659].

The Act also establishes a second group of federal standards, some of which are not directly related to electric utility ratemaking [660]. As with the first set of standards, the second group is not mandatory and need only receive consideration by each PUC and nonregulated utility. The standards are to be adopted after notice and hearing by each PUC and nonregulated utility if, and to the extent it is determined that the adoption is necessary to fulfill the purposes of the Act. This second group addresses master metering, automatic adjustment clauses, information to consumers, procedures for termination of electric service, and advertising [661].

The Act is not intended to prohibit a PUC or nonregulated utility from fixing a rate for essential needs of residential electric consumers that is lower than a rate based on costof-service [662]. Thus, lifeline rates are an exception to the federal standard on cost-ofservice. Moreover, in those areas where lifeline rates are not in effect 2 years after the enactment date ( $9 \mathrm{Nov} 78$ ), each PUC or nonregulated utility is required to determine after hearing whether such a rate should be implemented [663].

The Secretary of Energy, any affected electric utility, or any electric customer of an affected utility is given a right to intervene or participate in any ratemaking or regulatory proceeding [664]. This section is designed to initiate or provide for participation in proceedings considering the federal standards, or other concepts that would contribute to the gaals of the Act. Where a state or PUC does not provide compensation for customer intervenors, a utility will be liable for reasonable attorney's fees, expert witness fees, and other reasonable costs to a customer if (1) he contributes substantially to the approval of a position he advocates, and (2) this position relates to any one of the eleven standards set forth above [665]. Prior to awarding the expenses, however, PUCs and nonregulated utilities may require that (1) customers with similar interests have a common legal representative, and (2) the consumer demonstrate that intervention may be a significant financial hardship for the repayment of such costs [666]. Compensation by a utility is not required where a state or PUC provides alternative means for compensation to persons who would be unable to participate in the proceedings because of financial hardship, and represent an interest which would not otherwise be adequately represented [667].

The Act amends title II of the Energy Conservation and Production Act [668], to give the Secretary of Energy authority to provide financial assistance to PUCs, and nonregulated utilities to carry out their responsibilities [669]. The Secretary of Energy may establish 
guidelines to assure that the grants, for which appropriations are authorized, are expended solely for the stated purpose.

While federal ratemaking standards are not mandatory under the Act, solar users are assured that consideration will be given to standards potentially beneficial to solar commercialization [670]. Credible arguments could be made to show that TOD and interruptible rates, as well as load management techniques, are well suited to solar technologies and would provide benefits to both solar consumers and electric utilities. In general, all covered utilities will be required to consider ratemaking practices which may not have received consideration in the past, and which are directly beneficial to solar commercialization. Moreover, mechanisms are provided by which solar and other electricity consumers will have easier access to, and possibly more influence upon the ratemaking and regulatory processes. Solar consumers wishing to advocate a particular standard in a regulatory proceeding are guaranteed a federal right of intervention. More importantly, the cost barrier to challenging ratemaking practices may have been removed by the Act. Solar consumers, as a special interest group, could qualify for state, PUC, or utility reimbursement of legal expenses associated with any regulatory proceeding, if certain tests such as financial hardship are met.

Title II of the Act, regarding the Federal Energy Regulatory Commission (FERC) and Department of Energy (DOE) responsibilities [671], contains provisions which might affect ratemaking, service, and regulatory policies toward electricity-producing solar technologies such as wind and photovoltaic systems. The Federal Power Act is amended [672] to include the definitions of "small power production facility" and "cogeneration facility" [673]. A small power production facility produces electricity solely by the use, as a primary fuel, of biomass, waste, or renewable resources, and has a power production capacity not greater than $80 \mathrm{MW}$. A cogeneration facility produces electricity (from any fuel) and steam or other forms of useful energy (such as heat) for industrial, commercial, heating, or cooling purposes. The Conference Report provides that "[t].he definition of small power production facility includes solar electric systems, wind electric systems, systems which produce electric energy from waste or biomass, and electric energy storage facilities" [674].

A "qualifying small power production facility" is a small power production facility that (1) FERC determines, by rule, meets its requirements, and (2) is owned by a person not primarily engaged in the generation or sale of electric energy [675]. Thus, electric utilities would be excluded froll the definition since their primary business is the generation and sale of electric energy. Depending upon the requirements prescribed by FERC, a solar small power producer who uses a majority of the energy and occasionally sells excess to a utility, is likely to qualify.

Within a year from the enactment date, FERC is to prescribe rules which require electric utilities to offer to (1) sell electric energy to qualifying small power production facilities and qualifying cogeneration facilities, and (2) purchase electric energy from these facilities. The rules may not authorize these facilities to make any sale for purposes other than resale [676]. The rules are to ensure that the rates for the purchase from and sale of electric energy to these facilities will be just and reasonable to the utility's consumers and in the public interest, and not discriminatory against owners of these facilities [677]. The rates for the purchase of energy by electric utilities may not exceed the incremental cost to the electric utility of alternative energy [678], that is, the cost at which the utility would generate the electric energy or purchase it from another source [679]. 
After consultation with PUC's, electric utilities, and small power producers, and after public notice and opportunity for interested persons to comment, FERC is also required to establish rules under which small power producers may be exempted from the Federal Power Act, the Public Utility Holding Company Act, and state law pertaining to rate regulation of electric utilities [680]. FERC must determine that such exemption is necessary to encourage small power. production. Small power production facilities whose power production capacity exceeds $30 \mathrm{MW}$ will not be entitled to the above exemption [681]. One exception is that small power production facilities utilizing biomass as a primary energy source would be entitled to exemption from the Public Utility Holding Company Act and state regulation.

The provisions regarding small power producers are generally consistent with those in earlier proposals of the Act. If electricity-producing solar technologies qualify as small power production facilities, their owners will be benefitted by future rules prohibiting rate discrimination in the purchase of auxiliary energy and the sale of excess energy. Moreover, solar users are assured that electric utilities can no longer summarily refuse to purchase excess energy from qualifying small power production facilities. A solar small power producer might secure exemption from federal and state rate regulation where he considers such regulation detrimental to parallel operation with a utility. In general, for the qualifying solar small power producer, the Act resolves several issues that could have hindered the commercialization of electricity-producing solar technologies. 


\section{SECTION 9.0}

\section{CONCLUSIONS}

For practical, economic, and institutional reasons, decentralized solar technologies usually require an auxiliary energy system to assure continuous service through periods of adverse weather. Where electricity is the backup energy source, electric utility rates for the auxiliary service affect solar system economics and commercialization. Moreover, the type of rate structure utilized by electric utilities can govern the optimum size, design, and application of the solar technology.

Since solar users can exhibit low load factors, different costs to serve, and variable demands, they can be classified separately from other electric customers for ratemaking purposes. In the past, rates for auxiliary service reduced the utility bill savings a solar user expected to see. This practice hindered solar commercialization. Whether such a practice is unduly discriminatory and therefore unlawful depends upon the utility's cost to provide auxiliary service to solar users.

Studies using computer simulation techniques to determine the impact of solar auxiliary demands on electric utilities give conflicting results. The impact of solar on the utility ranged from beneficial effects (where off-peak recharge could be utilized) to adverse effects (where auxiliary demands coincide with the utility's peak demand period). Present studies will utilize data from actual solar home/utility situations to determine the impact of solar systems on electric utilities and the corresponding costs of providing auxiliary service. When the results of these studies become available, the legality of solar auxiliary rates different from traditional rates can be determined. It is clear, however, that where a solar system provides the utility capacity cost savings as well as energy cost savings, auxiliary service rates should reflect both savings components.

Federal and state governments should fund studies to determine the impact of various solar technologies on utilities. The studies should evaluate the basic solar designs commercially available, including electricity-producing systems. Moreover, the studies should be based upon actual operating data from solar and utility configurations, and should take into account variations in solar use in different regions of the country. Where utilities have conducted independent studies on costs-to-serve solar auxiliaries based on actual operating data, the results of these studies should be made available to the public.

Recently, PUCs in approximately one-fifth of the states filed solar auxiliary service rates that promote the commercialization of solar energy. In general, the rates are experimental and temporary, and are offered to only a limited number of customers. The rates are designed to allow the utilities to collect actual operating data on the impact of various solar technologies upon the utilities. Most solar rates provide the same promotional discount offered to all-electric customers. Other solar rates are designed for the purchase of only off-peak auxiliary energy and are thus lower than conventional rates. Still other solar rates are offered to customers who agree to have auxiliary service controlled by the utility under a load management scheme; the utility will provide service outside peak periods at reduced rates.

Solar rates, which reflect a subsidy to solar customers by other customers, are not necessarily invalid or illegal. Promotional allowances have been upheld in the courts where they were reasonably expected to provide ultimate benefits to all customers. 
Since the commercialization of solar energy is consistent with national policy goals of energy conservation and environmental protection, and can potentially reduce utility capacity expansion and fuel expenditures, promotional solar rates could benefit all the utility's customers.

One state has expanded its rate antidiscrimination law to provide that a utility may not consider the use of solar energy as a basis for charging higher rates. A solar customer is served under a.rate that he would otherwise have qualified for in the absence of the solar system. This law, which ends in 1982, is designed to promote the commercialization of solar energy in the near term. Legislatures and PUCs in other states interested in accelerating the commercialization of solar energy should consider similar legislation.

Rate structures based on time-of-day (TOD) rates, interruptible service, or load management appear to encourage solar use. Rates so based will help to assure that solar designs are compatible with utility system operullon. If melering, cointrul, and adminis.... trative costs are not prohibitive, regulators and utilities should glve serlous considerution to these rate types for auxiliary service to solar customers, as well as inverted and lif elìne ràtes.

The National Energy Act (NEA) requires PUCs and nonregulated utilities to consider federal ratemaking standards potentially beneficial to solar consumers. The NEA also makes it easier for electric consumers to challenge ratemaking practices and support the federal standards.

PUCs in a few states have policies that encourage utilities to purchase excess power generated by alternative energy sources, resulting in windmill and parallel generation rates applicable to other electricity-producing solar technologies. These rates allow for the sale of excess energy to the utility at a price equal to the utility's average cost of fuel or the rate charged for auxiliary service. In most states, whether a utility can refuse to purchase excess power from an electricity-producing solar system is still unsettled. The NEA however, requires FERC to establish rules that will require utilities to make these purchases if the solar system meets certain criteria to be formulated by FERC. The rules will also assure that rates for sales of electricity to and purchases of electricity from the users of electricity-producing solar systems are not discriminatory. The thrust of this portion of the NEA is to encourage the generation of electricity by alternative energy sources.

Solar users who find electric auxiliaries uneconomical for their application might consider an alternative form of backup energy, such as natural gas. If solar technologies affect gas utilities adversely, however, the same problem may arise. Other auxiliary energy devices, such as wood or coal burning stoves, are cheap and practical but may not satisfy local building codes.

The time is ripe for legislation or policies to eliminate rate discrimination against solar users. Promotional solar rates could be mandated as consistent with energy conservation goals and beneficial to all utility customers, as well as promoting commercialization of solar energy. Without such legislation, solar users will have to rely on existing antidiscrimination statutes, current PUC policies, and national rate reform. 


\section{REPERENCES}

1. R. G. Jones, H. M. Sramek, \& J. M. Pelster, Analysis of State Solar Energy Policy Options 2 (June 1976) (prepared for the Federal Energy Administration by the Energy Policy Project of the National Conference of State Legislatures, FEA Contract No. CO-12-60496-00) [hereinafter cited as Jones].

2. Id.

3. Id. at 3; A. Patton, Solar Energy for Heating and Cooling of Buildings 1 (1976). See 1 Office of Technology Assessment, Application of Solar Technology to Today's Energy Needs 19 (June 1978) [hereinafter cited as OTA Report].

4. OTA Report, supra note 3, at 18; H. Rau, Solar Energy 59 (1964).

5. OTA Report, supra note 3 , at 3-4.

6. See Jones, supra note 1 , at $3-4$.

7. It is possible to design solar systems with sufficient charging and storage capacity to eliminate the need for conventionally fueled auxiliary systems. However, the most common and economic designs include some for $m$ of auxiliary system. See generally B. Anderson, Solar Energy: Fundamentals In Building Design 235-40 (1977); G. Daniels, Solar Homes And Sun Heating 40-41 (1976); J. A. Duffie \& W. A. Beckman, Solar Energy Thermal Processes 271 (1974) [hereinafter cited as Duffie \& Beckmanl.

8. S. L. Feldman \& B. Anderson, The Public Utility And Solar Energy Interface: An Assessment of Policy Options 1 (31 Dec 76) (prepared for the Energy Research and Development Administration - Division of Solar Energy, ERDA Contract No. E(4918) - 2523) [hereinafter cited as Feldman \& Anderson].

9. A. Meinel \& M. Meinel, Applied Solar Energy 463 (1976). Contra, Asbury \& Mueller, "Solar Energy and Electric Utilities: Should They Be Interfaced" 195 Science 445 (4 Feb 77). The general conclusion reached by Asbury and Mueller is that electric utility systems and solar energy systems represent a poor technical match. Id. at 450. In their analysis, it was stressed that the economics of solar systems should be compared to off-peak utility fuels which implies very low breakeven costs for various solar energy applications. It was stated that because of the low costs of offpeak electricity, the most economical solar energy systems will utilize auxiliary fuels other than electricity.

10. B. Anderson, supra note 7 , at 235 .

11. Duffie \& Beckman, supra note 7, at 288-89.

12. E.g., Wash. Rev. Code Ann. $\$ 84.36 .410$ (Supp.1977), wherein it is provided that "Solar energy system means equipment which meets the minimum standards, if any, promulgated by the United States Department of Housing and Urban Development. .." Id. at \$ 84.36.410 (1).

13. E.g., Atlanta, Ga. Heating, Ventilating, And Air Conditioning Code art. 24, $\$ 2401.1$ (1977). The code provides that "Solar system utilization shall be considered as bonus or auxiliary energy." It further states that "A primary heating, ventilating and air 
conditioning system which conforms to this Code shall be required with energy utilized such as electricity, gas, or oil." Id.

Also, the heating requirements of standard building codes may be difficult to satisfy by a solar system without the aid of a conventionally fueled auxiliary system. See, e.g., BOCA Basic Mechanical Code $\$$ M-108.1 (1975) (72 degrees in the winter assuming outside temperatures given in the ASHRAE Handbook of Fundamentals); ICBO Uniform Building Code $\$ \$ 1311,1405$ (1976) (70 degrees, $3 \mathrm{ft}$ off the floor in habitable rooms of residential occupancies). The International Association of Plumbing and Mechanical Officials (IAPMO) adopoted a model code for solar heating and cooling systems in 1976. The portion dealing with auxiliary systems requires compliance with applicable codes. IAPMO Uniform Solar Energy Code $\$ 315(a)$ (1976).

14. Interview with Woody Leigh, Chief Appraiser, Midland Federal Savings, in Denver, Colorado (July 19, 1978). Mr. Leigh further indicated that additional constraints on loans to solar facilities may be imposed by secondary mortgage purchasers in the form of design and performance standards. The solar facility would be required to meet such standards before a secondary purchase could occur.

15. Feldman \& Anderson, supra note 8, at 139. For a comprehensive analysis of several legal issues pertaining to the utility and solar energy interface, see Dean \& Miller, Utilities at the Dawn of a Solar Age, 53 N.D.L. Rev. 329 (1977). For variations of the same article, see R. Bezdek, J. Margolin, T. Sparrow, G. Sponsler, A. Ezra, R. Spongberg, A. Miller, F. Meeker, E. Roseman, \& M. Misch, Analysis Of Policy Options For Accelerating Commercialization Of Solar Heating And Cooling Systems 358 (February 1978) (prepared for the Department of Energy, Assistant Secretary for Conservation and Solar Applications - Division of Solar Applications, Cóntract No. EX-76-G-01-2534) [hereinafter cited as Bezdek]; Environmental Law Institute, Legal Barriers To Solar Heating And Cooling Of Buildings 86 (March 1978) (prepared for the Department of E'nergy, Assistant Secrétary for Conservation and Solar Applleations - Division of Solar Applicntions, Contract No. EX-76-C-01-2528) (This report also contains discussion of various legal issues involving the market penetration of solar technologies other than those dealing with the solar/utility interface) [herelnafter cited as Legal Barriers to Solar]. N. Dean \& A. Miller, "Plugging Solar Power Into the Utility Grid," 7 Envt'l L. Rep. 50069 (1977).

16. See text accompaning notes $387-411$ infra.

17. Residential Solar Demonstration Program, 1 Working Papers on Marketing and Market Acceptance, ch. 6 at 14 (Spring 1978) (Preliminary Findings and Analysis, prepared for the Solar Demonstration Program Division of Energy, Building Technology and Standards Office of Policy Development and Research, United States Department of Housing and Urban Development) [hereinafter cited as HUD Report].

18. Id. ch. 6 at 15 .

19. Id. ch. 6 at 19 .

20. Id. ch. 6 at 16 .

21. The following discussion provides a broad overview of electric utility regulation. For more exhaustive economic and legal presentations of the regulatory process, see J. Bonbright, Principles of Public Utility Rates (1961); P. Garficld \& W. Lovejoy, 
Public Utility Economics (1964); I A. Kahn, The Economics of Regulation: Principles and Institutions (1970); 2 Id. (1971); A. Priest, Principles of Public Utility Regulation (1969).

22. For a comprehensive treatment of ratemaking as one aspect of the regulatory process, see J. Bonbright, supra note 21 , at 147-283; P. Garfield \& W. Lovejoy, supra note 27 , at $27-189 ; 1 \mathrm{~A}$. Kahn, supra note 21 , at $20-57 ; 1$ A. Priest, supra note 21 , at 45-226. See also Huntington, "The Rapid Emergence of Marginal Cost Pricing in the Regulation of Electric Utility Rate Structures," 55 B.U.L. Rev. 689, 698-718 (1975); Jones, "Judicial Determination of Public Utility Rates: A Critique," 54 B.U.L. Rev. 873, 875-94 (1974).

23. See Gainesville v. Gainesville Gas and Elec. Power Co., 65 Fla. 404, 62 So. 919, 921 (1913). Accord Iowa - Ill. Gas \& Elec. Co. v. Birmingham, 66 F. Supp. 441 (S.D. Iowa 1946); Preston County Light and Power Co. v. Renick, 145 W.Va. 115, 113 S.E.2d 378 (1960).

This section is confined to electric utility regulation even though similar issues arise in the context of gas utilities. There exist some differences, though, between electric and gas utilities in that gas storage presents a lesser magnitude problem than storage of electricity when considering plant capacity problems. Feldman \& Anderson, supra note 8 , at 154; 1 A. Priest, supra note 21 at 338 . Gas utilities are able to store their end product whereas electric utilities cannot, except for hydropumped storage:

24. See, e.g., Florida Power \& Light Co. v. City of Miami, 98 F.2d 180 (5th Cir. 1938), cert. denied, 305 U.S. 644 (1938); In re Niagara, Lockport \& Ontario Power Co., 229 App. Div. 295, 241 N.Y.S. 162 ( App. Div. 1930).

25. U.S. Const. art. I, $₫ 8$, cl. 3. The extent of federal rate regulation of electricity is that encompassed within the Federal Power Act and as promulgated by the Federal Power Gommission. See text aoompanying notes $61=83$ infra.

26. A. A. Kahn, supra note 21 , at 3,20 .

27. Id. at 20. Scc also $1 \Lambda$. Pricst, supra notc 21 , at 31 .

28. 1 A. Priest, supra note 21 , at 1 .

29. J. Bonbright, supra note 21 , at $11 ; 1 \mathrm{~A}$. Kahn, supra note 21 , at 11 .

30. In re Application of the Long Acre Elec. Light and Power Co., 1 P.S.C.R. 226, 24950 (1st Dist. N.Y. 1908). See generally J. Bonbright, supra note 21, at 10-13; P. Garfield \& W. Lovejoy, supra note 21 , at 15-19, 1 A. Priest, supra note 21 , at 36165. But see id. at 321-24.

31. Decreasing average unit costs as output increases may be apparent for the short run, where technology and a time period are fixed and output is increased until physical plant capacity is reached. In the long run, the decreasing average unit cost trend, in many instances, has reversed. See text accompanying notes 261-67 infra.

32. Diversity of demand is the ratio of the total of the maximum demands of individual customers occurring within a given period to the maximum total demand occurring 
during the same period. Less relative plant capacity is required to serve a system's peak or maximum total demand where high diversity exists compared to a system with low diversity. With more customers being served, there is a greater tendency that the maximum demand of each customer will occur at different times. $P$. Gar field \& W. Lovejoy, supra note 21 , at 18. For example: assume that Utility A is serving six customers each having a maximum demand of $10 \mathrm{~kW}$. Further assume that the peak demands of customers 1 to 3 occur coincidentally, at times when customers 4 to 6 have no demand and vice versa. The diversity of demand in this instance is 2 (total of maximum demands [60 kW]/ maximum total demand [30 kW]). Therefore, if Utility A maintained plant capacity of $30 \mathrm{~kW}$, all six customers could be served. Now, assume Utility A served only a portion of the market-customers 1 to 3. The diversity of demand in this case is 1 (total of maximum demands [30 $\mathrm{kW}] /$ maximum total demand $[30 \mathrm{~kW}])$. Here, Utility A would be required to maintain the same level of capacity as in the first case $(30 \mathrm{~kW})$ to serve only three customers. Capacity charges in the gecond case would theroforo be greater por customer than those in the first case.

33. P. Garfield \& W. Lovejoy, supra note 21 , at 17-19.

34. J. Bonbright, supra note 21 , at 10; P. Garfield \& W. Lovejoy, supra note 21, at 1,16.

35. 1 A. Priest, supra note 21 , at 1,4 .

36. MacDonald v. FPC, 505 F.2d 355, 363 (D.C. Cir. 1974); P. Garfield \& W. Lovejoy, supra note 21 , at $16 ; 1 \mathrm{~A}$. Kahn, supra note 21 , at 21 .

37. P. Garfield \& W. Lovejoy, supra note 21 , at 1 .

38. 94 U.S. 113 (1877).

39. Id. at 126 .

40. Id. at 131-32.

41. 291 U.S. 502 (1934).

42. Id. at $531,533,536$.

43. Id. at 525,537 .

44. 169 U.S. 466 (1898).

45. Id. at 526.

46. Id. at $546-47$.

47. See text accompanying notes 191-98 infra.

48. 289 U.S. 287 (1933).

49. 120 F.2d 625 (7th Cir. 1941), rev'd, 315 U.S. 575 (1942).

50. FPC v. Natural Gas Pipeline Co., 315 U.S. 575, 586 (1942). 
51. Id.

52. Id. at 585 .

53. 320 U.S. 591 (1944).

54. Id. at 602 .

55. Id.

56. Id. at 603.

57. Id. at 605 .

58. 262 U.S. 276, 289 (1923) (J. Brandeis, concurring in result, dissenting from the opinion).

59. Id. at $291-92$ (dissenting from the opinion).

60. See text accompanying notes $185-90$ infra.

61. DOE Organization Act, Pub. L. No. 95-91, 91 Stat. 565 (1977).

62. Id. at $\$ 401(a), 91$ Stat. 582.

63. Id. at $\$ 402(a)(1)(B), 91$ Stat. 584.

64. 16 U.S.C. SS 824, 824d, 824e (1976).

65. Id. at $\$ 824$ (b). In 1927 , the Supreme Court held that the transmission of electric current from one state to another is interstate commerce. Pub. Util. Comm'n of R.I. v. Attleboro Steam \& Elec. Co., 273 U.S. 83, 86 (1927).

66. 16 U.S.C. $\$ 824(c)(1976)$.

67. Id. at $\$ 824(d)$.

68. Id. at $\$ 824(\mathrm{~b})$.

69. Connecticut Light \& Power Co. v. FPC, 324 U.S. 515, 531 (1945).

70. Arkansas Power \& Light Co. v. FPC, 368 F.2d 376, 383 (8th Cir. 1966).

71. See text accompanying notes 671-81 infra.

72. 16 U.S.C. $\$ 824 d(a)(1976)$.

73. Pennsylvania Water \& Power Co. v. FPC, 193 F.2d 230, 234 (D.C. Cir. 1951), aff'd, 343 U.S. 414 (1952).

74. 16 U.S.C. $\$ 824 \mathrm{~d}(\mathrm{~b})(1976)$.

75. St. Michaels Utilities Comm'n v FPC, 377 F.2d 912, 915 (4th Cir. 196\%). 
76. 426 U.S. 271 (1976).

77. Id. at 276-77.

78. 16 U.S.C. $\$ 824 e(a)(1976)$.

79. Cities of Batavia et al., Ill. v. FPC, 548 F.2d 1056, 1057-58 (D.C. Cir. 1977).

80. For an explanation of fully distributed and incremental cost computation methods, see text accompanying notes 243-60 infra.

81. 18 C.F.R. $\$ 35.12(b)(2)(1977)$.

82. Allocation of cost of service including energy and demand rcoponsibilities is discussed in the text accompanying notes 243-60 infra.

83. 18 C.F.R. $\$ 35.12(b)(5)(1977)$.

84. See Railroad Comm'n v. Los Angeles Ry. Corp., 280 U.S. 145, 151-52 (1929).

85. Iowa-Ill. Gas \& Elec. Co. v. Birmingham, 66 F. Supp. 441,442 (S.D. Iowa 1946).

86. E.g., Ethington v. Wright, 66 Ariz. 382, 189 P.2d 209, 215-16 (1948); Edington v. New Mexico Pub. Serv. Comm'n, 74 N.M. 647, 397 P.2d 300, 302 (1964).

87. E.g., Smythe v. Ames, 169 U.S. 466, 526 (1898).

88. E.g., Town of Pocahontas v. Central Power \& Light Co., 152 Ark. 276, 244 S.W. 712 , 713-14 (1922), cert. denied, Central Power \& Light Co. v. Town of Pocahontas, 260 U.S. 755 (1922).

89. City of Seymour v. Texas Elec. Serv. Co., 66 F.2d 814, 816 (5th Cir. 1933); Iowa-Ill. Gas \& Elec. Co. v. Iowa City, 255 Iowa 1341 , 124 N.W.2d 840, 844 (1963).

90. E.g., Commonwealth Edison Co. v. Allis-Chalmers Mfg. Co., 207 F. Supp. 252, 254 (N.D. Ill. 1962), aff'd 315 F.2d 564 (7th Cir. 1963), cert. denied, Illinois v. Commonwealth Edison Co., 375 U.S. 834 (1963); City of Lithonia v. Georgia Pub. Serv. Comm'n, 238 Ga. 339 , 232 S.E.2d 832,833 (1977).

91. E.g., Southern Util. Co. v. City of Palatka, 86 Fla. 583, 99 So. 236, 239-40(1923), aff'd, 268 U.S. 232 (1925).

92. E.g., Cooper v. T'ampa Elec. Co., 154 Fla. 410, 17 So.2d 785, 787 (1944).

93. E.g., Minnesota Rate Cases, 230 U.S. 352, 433 (1913); Colorado Interstate Gas Co. v. FPC, 324 U.S. 581, 589 (1945), rehearing denied, 325 U.S. 891 (1945).

94. E.g., Montana - Dakota Util. Co. v. Northwestern Pub. Serv. Co., 341 U.S. 246, 25052 (1951); Cooper v. Tampa Elec. Co., 154 Fla. 410, 17 So.2d 785, 786-87 (1944).

95. See Terminal R.R. Ass'n v. United States, 266 U.S. 17, 30-31 (1924).

96. P. Garfield \& W. Lovejoy, supra note 21 , at $260 ; 1 \mathrm{~A}$. Kahn, supra note 21 , at 10 n.36. See 1. Stelzer, Rate Structure Revision: A Federal or State Problem, Table A 
Col. 1 (1977) (National Economic Research Associates Rate Structure Revision Survey).

97. Regarding state commissions, see generally E. Berlin, C. Cicchetti, \& W. Gillen, Perspective on Power 53-79 (1974) [hereinafter cited as Berlin]; P. Garfield \& W. Lovejoy, supra note 21 , at 260-68; 1 A. Kahn, supra note 21 at 10 n.36; 1 A Priest, supra note 21 , at $25-33$.

98. P. Garfield \& W. Lovejoy, supra note 21, at 262, 1 A. Priest, supra note 21, at 29.

99. P. Garfield \& W. Lovejoy, supra note 21 , at $262 ; 1$ A. Priest, supra note 21 , at 29-30.

100. 1 A. Priest, supra note 21 , at 30 .

101. I A. Kahn, supra note 21 , at 10 n.36; I. Stelzer, supra note 96 , at Table A Col. 1 , A-5.

102. I A. Kahn, supra note 21 , at 10 n.36. See I. Stelzer, supra note 96 at Table A Col. 3.

103. 1 A. Kahn, supra note 21 , at 10 n.36.

104. See, e.g., Ariz. Const. art. 15, $\$ 1$.

105. See, e.g., Ill. Ann. Stat. Ch. $1112 / 3$, \$ 1 (Smith-Hurd 1966).

106. E.g., N.Y. Pub. Serv. Law $\$ 1$ (McKinney 1955).

107. E.g., Colo. Rev. Stat. $\$ 40-1-101$ (1973).

108. Pub. Util. Comm'n of R.I. v. Attleboro Steam \& Elec. Co., 273 U.S. 83 (1927).

109. N.Y. Pub. Serv. Law $\$$ 5.1.b. (Mc Kinney Supp. 1977).

110. Wis. Stat. Ann. $\$ 196.02$ (West 1957).

111. Wis. Stat. Ann. \$196.01 (West Supp. 1977).

112. Colo. Rev. Stat. $\$ 40-1-103(1)(1973)$.

113. P. Garfield \& W. Lovejoy, supra note 21, at 261-62. See I. Stelzer, supra note 96 at Table A Col. 4.

114. N.Y. Pub. Serv. Law $\$ 65$ (McKinney 1955); Wis. Stat. Ann. \$\$ 196.01-.03 (West 1957).

115. Colo. Rev. Stat. $\$ 40-1-103(2)$ (1973). E.g., Western Colo. Power Co. v. Pub. Util. Comm'n, 159 Colo. 262, 280, 411 P.2d 785, 794-95 (1966), appeal dismissed, 385 U.S. 22, rehearing denied 385 U.S. 984 (1966).

116. Colo. Const. art. XXV. 
117. City \& County of Denver v. Pub. Util. Comm'n, 181 Colo. 38, 45, 507 P.2d 871, 874 (1973).

118. City of Loveland v. Pub. Util. Comm'n, 580 P.2d 381, 383-84 (Colo. 1978).

119. See generally Bezdek, supra note 15, at 377-81; Dean \& Miller, supra note 15, at $345-50$; N. Dean \& A. Miller, supra note 15, at 50076-78; Legal Barriers to Solar, supra note 15 , at $98-103$.

120. See text accompanying notes 131-60 infra.

121. Rate and service discrimination is given extensive treatment in the text accompanying notes 462-564 infra. That portion of the article addresses the issues of whether a utility can refuse to provide backup service to a solar equipped facility, and whether a utility can charge rates different than those charged to regular customers for backup service to a solar-equipped facility and thereby discriminate for or against solar.

122. N.Y. Pub. Serv. Law $\$ 65.1$ (McKinney 1955).

123. Id. at $\$ 66.5$.

124. Wis. Stat. Ann. $\$ 196.03(1)$ (West 1957).

125. Waukesha Gas \& Electric Co. v. Railroad Comm'n of Wis., 181 Wis. 281, 194 N.W. 846 (1923).

126. Wis. Stat. Ann. $\$ 196.37$ (1) (West 1957).

127. Colo. Rev. Stat. \$ 40-3-101(1) (1973).

128. Id. at $\$ 40-3-101(2)$.

129. Id. ul \& 40=3=102.

130. Mountain States Tel. \& Tel. Co. v. Pub. Util. Comm'n, 345 F. Supp. 80 (D. Colo. 1972).

131. The duty to serve and service discrimination are discussed in detail in the text accompanying notes 552-64 infra.

132. The Minnesota Rate Cases, 230 U.S. 352, 433-35 (1913).

133. Banton v. Belt Line R. Corp., 268 U.S. 413, 422-23 (1925).

134. Smith v. Il. Bell Tel. Co., 282 U.S. 133, 160 (1930).

135. FPC v. Hope Natural Gas Co., 320 U.S. 591, 603 (1944); City of Detroit v. Mich. Pub. Serv. Comm'n, 308 Mich. 706, 14 N.W.2d 784, 784-85 (1944).

136. Central Ill. Public Service Co. v. Ill. Commerce Comm'n, 5 Ill.2d 195, 125 N.E.2d 269,273 (1955). 
137. J. Bonbright, supra note 21 , at 66 . See also P. Garfield \& W. Lovejoy, supra note 21 , at 138 .

138. Berlin, supra note 97 , at 20,22 . See also J. Bonbright, supra note 21 , at 82 .

139. J. Bonbright, supra note 21 , at 69-70. The cost-of-service concept runs into some difficulty when one attempts to define cost. Costs can be defined as total costs to the utility or costs of supplying specific services, e.g., residential electric service. The problem arises when the sum of the costs specifically allowable to different classes does not equal the total costs of supplying all the services. When considering rate base, a controversy as to the proper interpretation of the cost-of-service principle arises between advocates of an actual cost or original cost basis of rate control and supporters of a reproduction cost basis associated with fair value. The cost-of-service concept also must consider the period of time over which rates should attempt to parallel costs. The time period creates a controversy between short-run costs and long-run costs. See generally id. at 71-78.

140. North Carolina ex rel. Util. Comm'n v. Edmisten, 291 N.C. 45 l, 232 S.E.2d 184, 194 (1977).

141. Georgia Power Co. v. Allied Chemical Corp., 233 Ga. 558, 212 S.E.2d 628, 630 (1975).

142. For a brief discussion of value-of-service as a test for reasonableness, see text accompanying notes $150-58$ infra.

143. Price elasticity is explained infra at note 152 .

144. Re Sierra Pacific Power Co., 10 P.U.R.4th 461, 465 (Nev. Pub. Serv. Comm'n 1975).

145. Re Iowa Power and Light Co., 20 P.U.R.4th 397, 413 (Iowa State Commerce Comm'n 1977).

146. Re The Kansas Power and Light Co., 8 P.U.R.4th 337, 378-79 (Kan. State Corp. Comm'n 1975).

147. Re Lincoln Service Corp., 1 P.U.R.4th 511, 517 (Wyo. Pub. Serv. Comm'n 1973).

148. Cost-of-service studies are given brief treatment in the text accompanying notes 243-60 infra.

149. For the extent of cost-of-service studies pertaining to solar equipped facilities, see text accompanying notes $434-61$ infra.

150. See supra note 139 .

151. See generally Berlin, supra note 97 , at 22 ; J. Bonbright, supra note 21 at $82-92$; P.Garfield \& W. Lovejoy, supra note 21, at 142-45; Huntington, supra note 22, at 715-16.

152. Elasticity of demand is a measure of the responsiveness or sensitivity in quantity of goods or services demander or ronnsumed to changes in price. Elasticity is the percentage change in quantity demanded caused by a one percent change in price or the percentage change in quantity demanded over the percentage change in price. 
A good or service having a price elasticity of demand between 0 and negative $1(-1)$ is said to be price inelastic (a good or service totally insensitive to price is called perfectly price inelastic and has a zero price elasticity). A good or service with a price elasticity greater than one is said to be price elastic. A price elastic good or service has a greater than proportional percentage change in quantity demanded for a given percentage change in price. See Berlin, supra note 97 at 117-125 app. A (Defining and Measuring the Price Elasticity of Demand for Electricity).

For the results of empirical studies measuring estimates of price elasticity of demand for various classes of electricity consumers, see Berlin, supra note 97, at 119-123; Electric Utility Rate Design Study, Rate Design and Load Control 87-92 (November 1977) (report to the National Association of Regulatory Utility Commissioners [NARUC] sponsored by the Electric Power Research Institute, Inc., [EPRD, the Edison Electric Institute [EED, the American Public Power Association [APPA], and the National Rural Electric Cooperative Association [NRECA], [hereinafter cited as Rate Design Study]. This report is a summary and evaluation of research done in 1976 and early 1977 by the Rate Design Study Group in the area of (1) technical feasibility of time-differentiated rates, (2) technical feasibility of direct load controls, and (3) desirability of time-differentiated rates, load controls, or both to control and shift peak period use. Some 49 other reports have been or are being completed on these areas.

153. J. Bonbright, supra note 21 , at $83 ; 1$ A. Kahn, supra note 21 , at 64 .

154. This term is not to be construed as synonomous with unjust discrimination in the legal sense that is prohibited by public utility laws. See text accompanying notes 462-5 12 infra.

155. J. Bonbright, supra note 21 , at $87-90$.

156. 169 U.S. $466,546-47$ (1898).

157. Re Milwaukee Gas Light Co., 51 P.U.R. (n.s.) 299, 307 (Wis. Pub. Serv. Comm'n 194.3).

158. E.g., Northern Pacific Railway Co. v. North Dakota, 236 U.S. 585, 599 (1915).

159. For a more detailed discussion of all costs considered in the ratemaking process, see text accompanying notes 231-42 infra.

160. P. Gar field \& W. Lovejoy, supra note 21 , at 144 .

161. 315 U.S. 575,584 (1942).

162. J. Bonbright, supra note 21 , at 147 .

163. Id. at 149 .

164. Berlin, supra note 97 , at 59 .

165. P. Garfield \& W. Lovejoy, supra note 21 , at 44 . Revenue requirement can be summarized by the following simple equation. Total Cost of Service $=$ Revenue Require ment $(R R)=E+d+T+(V-D) R$, where 
$E=$ Operating expenses

$d=$ Depreciation expenses

$T=$ Taxes

$\mathrm{V}=$ Gross valuation of property serving the public

$\mathrm{D}=$ Accrued depreciation

$\mathrm{V}-\mathrm{D}=$ Rate base (net valuation)

$R=$ Rate of return (a percentage)

$(\mathrm{V}-\mathrm{D}) \mathrm{R}=$ Fair return or earnings allowed on the rate base

Id. at $44-45$.

166. J. Bonbright, supra note 21 , at 151-58.

167. North Carolina ex rel. Util. Comm'n v. General Tel. Co. of the Southeast, 285 N.C. 671,208 S.E.2d 681, 692 (1974).

168. See text accompany notes $137-58$ supra.

169. E.g., Tobacco River Power Co. v. Pub. Serv. Comm'n, 109 Mont. 521, 98 P.2d 886, 889 (1940); Re Inter-Mountain Teleph. Co., 15 P.U.R.3d 272, 276 (Tenn. Pub. Serv. Comm'n 1956); L.S. Ayres \& Co. v. Indianapolis Power \& Light Co., 351 N.E.2d 814, 819 (Ind. Ct. App. 1976).

170. 1 A. Priest, supra note 21 , at $45-46$.

171. E.g., Re Hartford Electric Light Co., 6 P.U.R.4th 209, 228 (Conn. Pub. Util. Comm'n 1974); Re United Illum. Co., 7 P.U.R.4th 417, 430 (Conn. Pub. Util. Comm'n 1974); Re Detroit Edison Co., 3 P.U.R.4th 209, 214 (Mich. Pub. Serv. Comm'n 1974).

172. E.g., Re Georgia Power Co., 9 P.U.R.4th 381, 385 (Ga. Pub. Serv. Comm'n 1975) (twelve months estimated); Re Test Periods in Rate Cases, 22 P.U.R.4th 611,613 N.Y. Pub. Serv. Comm'n statement of policy on test periods 1977) (operating results for 12-month period expiring at end of calendar quarter no earlier than 150 days before date of filing and the projected operating results for the new 12-month rate period); Re Baltimore Gas and Electric Co., 17 P.U.R.4th 44, 58 (Md. and Pub. Serv. Comm'n 1976). See generally Note, "The Use of the Future Test Year in Utility Rate-Making," 52 B.U.L. Rev. 791 (1972).

It is required by the FERC that utilities supply cost-of-service data for both the most recent 12-month period for which actual data are available and estimated cost-of-service data for the 12-month period immediately following the effective date of the new rate schedule. See 18 C.F.R. $\$$ 35.13(b)(1); American Public Power Ass'n. v. FPC, 522 F.2d 142, 145 (D.C. Cir. 1975).

173. 1 A. Priest, supra note 21 , at 47 .

174. For indepth discussions of the inclusion of operating expenses in a utility's annual revenue requirement, see generally $J$. Bonbright, supra note 21 , at 199-207 (depreciation as operating expense); P. Garfield \& W. Lovejoy, supra note 21 , at 4656, 94-114; 1 A. Kahn, supra note 21 , at 26-35; 1 A. Priest, supra note 21 , at. $47-138$. 
175. P. Gar field \& W. Lovejoy, supra note 21 , at 46 .

176. Id.

177. 143 U.S. $339,345-46$ (1892).

178. 1 A. Priest, supra note 21 , at 51 .

179. See, e.g., Galveston Elec. Co. v. City of Galveston, 258 U.S. 388 (1922); Georgia Ry. \& Power Co. v. Railroad Comm'n, 262 U.S. 625 (1923); Southwestern Bell Tel. Co. v. Kan. State Corp. Comm'n, 192 Kan. 39, 386 P.2d 515 (1963); Re Kan. Power and Light Co., 20 P.U.R.4th 55 (Kansas State Corp. Comm'n 1977).

180. See, e.g., West Ohio Gas Co. v. Pub. Util. Comm'n, 294 U.S. 63 (1935); Central Maine Power Co. v. Pub. Util. Comm'n, 153 Me. 228, 136 A.2d 726 (1957); Re Pub. Serv. Co. of North Carolina, 19 P.U.R.4th 109 (North Carolina Util. Comm'n 1977) (only advertising associated with conservation can be included as an operating expense); Re Pub. Serv. Co. of Colo., 13 P.U.R.4th 40 (Colo. Pub. Util. Comm'n 1.975).

181. See, e.g., Northwestern Bell Tel. Co. v. Spillman, 6 F.2d 663 (D. Neb. 1925); Cheltenham \& A. Sewerage Co. v. Pub. Serv. Comm'n, 122 Pa. Super. Ct. 252, 186 A. 149 (Super. Ct. 1936); Re Toledo Edison Co., 17 P.U.R.4th 433 (Ohio Pub. Util. Comm'n. 1976).

182. See, e.g., City of Knoxville v. Knoxville Water Co., 212 U.S. 1 (1909); Lindheimer v. Illinois Bell Tel. Co., 292 U.S. 151 (1934); Central Maine Power Co. v. Maine Pub. Util. Comm'n, 156 Me. 295, 163 A.2d 762 (1960).

183. J. Bonbright, supra note 21 , at $157 ; 1$ A. Kahn, supra note 21 , at 36 .

184. See generally J. Bonbright, supra note 21, at 159-237; P. Garfield \& W. Lovejoy, supra note 21 , at $56-83$; 1 A. Kahn, supra note 21 , at $35-41,107-17$; 1 A. Priest, supra note 21 ; a $139-90$.

185. J. Bonbright, supra note 21 , at 161 ; P. Garfield \& W. Lovejoy, supra note 21 , at $73-$ 75 ; 1 A. Priest, supra note 21 , at $141,142-53$.

186. P. Garfield \& W. Lovejoy, supra note 21 , at $60-61 ; 1$ A. Priest, supra note 21 , at $13 y-40$.

187. 262 U.S. 276 (1923).

188. 320 U.S. 591 (1944).

189. P. Garfield \& W. Lovejoy, supra note 21 , at $75 ; 1$ A. Priest, supra note 21 , at 142 .

190. 227 Ark. 436, 441, 299 S.W.2d 208, 211 (1957).

191. 169 U.S. 466 (1898).

192. P. Garfield \& W. Lovejoy, supra note 21 , at 57 . 
193. J. Bonbright, supra note 21 , at 229 .

194. Berlin, supra note 97 , at 62 n.t; 1 A. Priest, supra note 21 , at 140 .

195. Berlin, supra note 97 , at 62 n.u; 1 A. Priest, supra note 21 , at $156-57$.

196. Ariz. Const. art. 15, \$ 14 .

197. Simms v. Round Valley Light \& Power Co., 80 Ariz. 145, 294 P.2d 378, 380 (1956). See also City of Tuscon v. Citizen Utilities Water Co., 17 Ariz. App. 477, 498 P2d 551,556 (Ct. App. 1972).

198. Arizona Corp. Comm'n v. Arizona Water Co., 85 Ariz. 198, 335 P.2d 412, 414 (1959).

199. N.Y. Pub. Serv. Law $\$ 97 . i$. (McKinney Supp. 1977).

200. N.Y. Pub. Serv. Law \$S 72,89-j (McKinney 1955).

201. Berlin supra note 97 , at $62-63,62-63$ n.v; 1 A. Priest, supra note 21 , at 155 .

202. See generally J. Bonbright, supra note 21 , at $238-83 ; 1$ A. Kahn, supra note 21 , at 42-54; P. Garfield \& W. Lovejoy, supra note 21 , at 114-34; 1 A. Priest, supra note 21 , at 191-226.

203. P. Garfield \& W. Lovejoy, supra note 21, at 116; I A. Priest supra note 21 , at 191.

204. 262 U.S. 679 (1923).

205. 320 U.S. 591 (1944).

306. 262 U.S. at $682-83$.

207. 320 U.S. at 603 .

208. See J. Bonbright, supra note 21 , at 240-56; P. Garfield \& W. Lovejoy, supra 21 , at 119.

209. See J. Bonbright, supra note 21 , at 256-59; P. Garfield \& W. Lovejoy, supra note 21 , at 119.

210. For an example of the calculation made to determine the costs of capital for an individual utility, see J. Bonbright, supra note 21, at 243; P. Garfield \& W. Lovejoy, supra note 21 , at 124 ; Huntington, supra note 22 , at 700 n.64.

211. J. Bonbright, supra note 21, at 241; P. Garfield \& W. Lovejoy, supra note 21, at 123.

212. P. Garfield \& W. Lovejoy, supra note 21 , at 120-21.

213. 390 U.S. 747 (1968).

214. Id. at $7 \% 4-\% \%$ 
215. Id. at 791.

216. For comprehensive discussions of rate structure regulation and designs, see generally J. Bonbright, supra note 21, at 287-368; P. Garfield \& W. Lovejoy, supra note 21 , at $134-89 ; 1$ A. Kahn, supra note 21 , at $54-57,63-122 ; 1$ A. Priest, supra note 21, at 327-45; Rate Design Study, supra note 152, at 9-54.

217. P. Garfield \& W. Lovejoy, supra note 21 , at $145 ; 1$ A. Kahn, supra note 21 , at 54 ; 1 A. Priest, supra note 21, at 344. Specific statutes and case law interpretations dealing with the just and reasonable standard are provided in the text accompanying notes 72-77, 121-58 supra. For a corresponding discussion of statutes and case law interpretations regarding discrimination, see text accompanying notes 462-512 supra.

218. Berlin, supra note 97 , at 53 ; J. Bonbright, supra note 21 , at 34 n.8; P. Garfield \& $\bar{W}$. Lovejoy, supra note 21 , at $138 ; 1 \mathrm{~A}$. Kahn, supra note 21 , at 55 n.86. Typically, commissions (1) order the utilities to file proposed rate schedules, (2) review the proposed rate schedules, and (3) where controversy is apparent, order a formal hearing and render decisions on the proposal. See, e.g., Re Boston Edison Co., 24 P.U.R.3d 153, 159 (Mass. Dept. of Pub. Util. 1958). See also 1 A. Priest, supra note 21 , at $342-43$.

219. See text accompanying notes $261-67$ infra.

220. J. Bonbright, supra note 21, at 291. See also Rate Design Study, supra note 152, at 17.

221. J. Bonbright, supra note 21 , at 292. See also 1 A. Priest, supra note 21, at 329 ; Rate Design Study, supra note 152, at 17-18.

222. See generally J. Bonbright, supra note 21, at 109-20.

223. Id. at 295-301.

224. Re Consolidated Edison Co., 8 P.U.R.4th 475, 479 (N.Y. Pub. Serv. Comm'n 1975).

225. Re Madison Gas \& Elec. Co., 5 P.U.R.4th 28, 35 (Wis. Pub. Serv. Comm'n 1974). See also Berlin, supra note 49 , at 23 .

226. See, e.g., Western Systems Coordinating Council, Reliability and Adequacy of Electric Service 9H-1, 2 April 1, 1977 (reply to F PC Order 383-4, Docket R-362 Information to be reported by regional councils on coordinated regional bulk power supply programs). For a discussion of the need for excess generating capacity to protect against loss of load resulting from unplanned outages, see Gainesville Util. Dept. v. Florida Power Corp., 402 U.S. 515, 517-20 (1971).

227. For example, if a utility system during a given 24-hour period supplied customers with a total of 168,000 kilowatt-hours $(\mathrm{kWh})$ of energy and recorded a peak demand during that period of 10,000 kilowatts $(\mathrm{kW})$, the load factor for that period would be $70 \%[(168,000 / 24) / 10,000]$.

228. P. Garfield \& W. Lovejoy, supra note 21 , at 153. 
229. Id. See also note 32 supra.

230. Id. at 154 .

231. Id. at 44 .

232. Huntington, supra note 22 , at $707-08$.

233. See Berlin, supra note 97 , at $34-35$.

234. Huntington, supra note 22 , at 708 .

235. J. Bonbright, supra note 21 , at $318-19 ; 1$ A. Kahn, supra note at 65-66.

236. See 1 A. Kahn, supra note 21 , at $65-67$.

237. J. Bonbright, supra note 21 , at $319 ; 1$ A. Kahn, supra note 21 , at 72 n.21.

238. J. Bonbright, supra note 21 , at $320-23,328-29$.

239. See id. at 331-36, 395-99; 1 A. Kahn, supra note 21 , at $83-86$. The SRMC when capacity is totally utilized and incapable of producing an additional $\mathrm{kWh}$ is the marginal cost of excluding the highest unsuccessful bidder for the limited output (market clearing price) rather than the cost of additional capacity. J. Bonbright, supra note 21 , at 323 .

240. J. Bonbright, supra note $21,324-28 ; 1$ A. Kahn, supra note 21 , at 75-77.

241. See J. Bonbright, supra note 21 , at $400 ; 1 \mathrm{~A}$. Kahn, supra note 21 , at 86 . However, SRMC cannot totally be disregarded in a scheme of rate making based on marginal costs. If time differential pricing between on- and off-peak periods is used in the rate design, short-run marginal fuel costs may need to be determined depending on the methodology used. See text accompanying notes $25 b-b 0$ infrá.

242. L. Flax \& M. Drazen, Current Proposals for Changes in the Design of Electric Utility Rates 56 (1976).

243. For general discussions of fully distributed costs and studies, see J. Bonbright, supra note 21 , at $337-68 ; 1$ A. Kahn, supra note 21 , at 150-58.

244. Rate Design Study, supra note 152, at 24. Much of the following discussion is based upon the above cited report. See also, J. Bonbright, supra note 2l, at 346-66.

245. See J. Bonbright, supra note 21 , at $349-50$. The incremental fuel cost of a large eastern U.S. electric utility in 1973 varied from $3.3 \mathrm{mills} / \mathrm{kWh}$ at minimum load to $9.51 \mathrm{mills} / \mathrm{kWh}$ at peak. Berlin, supra note 97 , at 35 Table 3-2.

246. See J. Bonbright, supra note 21 , at $355-56 ; 1$ A. Kahn, supra note 21 , at 79 .

247. J. Bonbright, supra note 21 , at 351 ; Rate Design Study, supra note 152 , at 26 .

248. See J. Bonbright, supra note. 21 , at 352; R. Caywood, Electric Utility Rate Economics 156-61 (1972 ed.). 
249. See J. Bonbright, supra note 21, at 352; R. Caywood, supra note 248, at 161-62.

250. Rate Design Study, supra note 152 , at 26 .

251. Id. at 27.

252. Selection of a rating period for a summer peaking utility may proceed as follows: (1) Off-peak is defined to be the period in which load can be satisfied by base load units; (2) Since these units can meet $70 \%$ of the demand during the summer and winter peaks, hours on the summer peak day when the demand was less than $70 \%$ are defined as off-peak during the summer. Similarly, hours on the winter peak day when the demand was less than $70 \%$ are defined as off-peak for the winter period; (3) Weekends and holidays are assumed to be off-peak periods; (4) Peak period is defined to be hours during the summer peak day in which the demand exreperien the winter peak demand (approximately 8096 of summer peak demand); and (5) The remaining hours are included in the uff=peuk verlod slnce it is deemed impractical to have three daily rating periods. A rating period such as the following may result:

Peak Period

June - 3epternber

Off-Peak Period
9:00 a.m.-10:00 p.m.

10:00 p.m.- 9:00 a.m.
Octuber - May

6:00 a.m. $-10: 00$ p.m.

10:00 p.m.- 6:00 a.m.

It is also possible to arrive at rating periods based on Loss of Load Probability, the probability that system load will exceed system capability. Id. at 28,31 .

253. Id. at 29. Other methods; e.g., number of hours in each period or number of $\mathrm{kWh}$ in each period, are available to allocate demand costs to rating periods. Id. at 30 .

254. J. Bonbright, supra note 21 , at $356 ; 1$ A. Kahn, supra note 21 , at 79.

255. See Berlin, supra note 97 , at $43-44$; J. Bonbright, supra note 21 , at 359 ; $1 \mathrm{~A}$. Kahn, supra note 21 , at 90 . A rate structure designed to measure and bill demand and energy on-peak but only energy off-peak was listed as me nossihility in the R.ate Design Study, supra note 152, at 32 .

256. See text accompanying notes 237-41 supra. Marginal cost advocates are almost in unanimous agreement on this point. See, e.g., Re Madison Gas \& Elec. Co., 5 P.U.R.4th 28, 34-35; Berlin, supra note 97, at 23-25; J. Bonbright, supra note 21, at 336; Rate Design Study, supra note 152, at 34 .

257. Joskow, "Applying Economic Principles to Public Utility Rate Structures. The Case of Electricity," in Studies in Electric Utility Regulation 44 (Cicchetti \& Jurewitz eds. 1975) [hereinafter cited as Cicchetti \& Jurewitz]. See also Huntington, supra note 22 , at 730 .

258. Several methodologies are available for computing LRMC. See generally Berlin, supra note 87, at 167-68 (marginal cost pricing bibliography); Rate Design Study, supra note 188 , at $42 \mathrm{n} .47$.

259. See Rate Design Study, supra note 152, at 32-39.

260. Id. at 36 . 
261. J. Bonbright, supra note 21 , at $11-13$; 1 A. Kahn, supra note 21 , at $124-30$.

262. See, e.g., Berlin, supra note 97, at 1-11; Brancato, "New Approaches to Current Problems in Electric Utility Rate Design," 2 Colum. J. Envt'l L., 40, 46-47 (1975); Huntington, supra note 22, at 692, Samuelson, "Battle Lines are Being Generated for Reform of Electric Utility Rates," 8 Nat'l J., 1474 (1976).

263. Brancato, supra note 262 , at $49-51$; Huntington, supra note 22 , at 693 .

264. Brancato, supra note 262, at 53-54; Huntington, supra note 22, at 693 .

265. Brancato, supra note 262, at 51-53; Huntington, supra note, at 694 .

266. Brancato, supra note 262 , at 46 ; Hunting ton, supra note 22 , at 693 .

267. Brancato, supra note 262 , at $54-56$; Huntington supra note 22 at $694-95$.

268. P. Garfield \& W. Lovejoy, supra note 21 , at 155 .

269. A declining block rate structure incorporating the customer charge would appear in the following form:

First $10 \mathrm{kWh}$ or less

Next $30 \mathrm{kWh}$

Next $60 \mathrm{kWh}$

Next $100 \mathrm{kWh}$

All over $200 \mathrm{kWh}$
$\$ 3.00$

0.045 per $\mathrm{kWh}$

0.039 per $k W h$

0.027 per $\mathrm{kWh}$

0.020 per $\mathrm{kWh}$

See id.

270. S. Elstein, State Initiatives for Electric Utility Rate Reform 3-4 (1978). (The Council of State Governments). See I. Stelzer, supra note 96, at Table C col. 2. In Washington, the state commission has not recently approved declining block rates in the residential sector. Id. at C-13.

271. See S. Elstein, supra note 270 , at 4 ; I. Stelzer, supra note 96 , at Table C col. 4.

272. I. Stelzer, supra note 96 , at $\mathrm{C}-6$.

273. Id.

274. Id. at C-9.

275. S. Elstein, supra note 270 , at 4; I. Stelzer, supra note 96 , at C-2, 11 . The 88 Colorado generic hearing has been completed and a decision is expected in 1979.

276. P. Garfield \& W. Lovejoy, supra note 21, at 154. For a legal and economic discussion of flat rates, see Aman \& Howard, "Natural Gas and Electric Utility Rate Reform: Taxation Through Ratemaking?" 28 Hast. L. J. 1085, 1111-13 (1977).

277. A typical flat-rate structure contains a monthly customer charge of $\$ 1.40$ and a flat energy charge of $\$ 0.04194$ per $\mathrm{kWh}$. Commonwealth Edison Co., Residential Service Rate 1. 
278. See text accompanying notes $270-75$ supra.

279. S. Elstein, supra note 270 , at 5 . See I. Stelzer, supra note 96 , at Table C cols.

280. See I. Stelzer, supra note 96 , at Table C cols. 5-6.

281. Re Potomac Electric Power Co., 3 P.U.R. 4th 65 (D.C. Pub. Serv. Comm'n 1974).

282. Id. at $79-80$.

283. Consol. Edison Co., Case 26309, 13 N.Y.P.S.C. 1491,1528 (1973).

284. S. Elstein, supra note 270 , at 5; I. Stelzer, supra note 96 , at C-1, 4, 10.

285: A typical inverted rate structure contains a service charge of $\$ 2.50$, a charge of $\$ 0.0385$ per $\mathrm{kWh}$ for the first $500 \mathrm{kWh}$ consumed, a chit'ge ul $\$ 0.0415$ per $\mathrm{kWh}$ fur the next $500 \mathrm{kWh}$ consumed, and a chlarge uf $\$ 0.0445$ per $\mathrm{kWh}$ for additional consumption over $1,000 \mathrm{kWh}$. Detroit Edison Co., Residenlial Electric Service, Domestic, Schedule Dl. For a legal and economic discussion of inverted rates, see Aman \& Howard, supra note 276 at 1107-11.

286. See Mann, "Rate Structure Alternatives for Electricity," 99 Pub. Util. Fort., Jan. 20, 1977, at 31 (issue no.2); S. Elstein, supra note 270, at 5.

287. S. Elstein, supra note 270 , at 5 .

288. I. Stelzer, supra note 96 , at $\mathrm{C}-3,4$.

289. Virginia Elect. \& Power Co., 95 P.U.R.3d 281 (Va. St. Corp. Comm'n 1972). The reviser rates apeared as follows:

$\begin{array}{ll}\text { First } 90 \mathrm{kWh} & \$ 0.05490 \text { per } \mathrm{kWh} \\ \text { Next } 120 \mathrm{kWh} & \$ 0.02797 \text { per } \mathrm{kWh} \\ \text { Next } 390 \mathrm{kWh} & \$ 0.01787 \text { per } \mathrm{kWh} \\ \text { All over } 600 \mathrm{kWh} & \$ 0.02197 \text { per } \mathrm{kWh}\end{array}$

290. I. Stelzer, supra note 96 , at $\mathrm{C}-3,9,11$.

291. Rate Design Study, supra note 152, at 40. For a legal and economic discussion of lifeline rates, see Aman \& Howard, supra note 276, at 1113-16.

292. S. Elstein, supra note 270 , at 10 .

293. Id. citing J. Pace, Lifeline Rates and Energy Stamps (1975) (National Ecơnomic Research Associates, Inc.). See also Environmental Law Institute, "Lifeline RatesAre They Useful? (Jan. 1976) (Energy Conservation Project Report no. 4,) Howe, "Lifeline Rates-Benefits for Whom?" 97 Pub. Util. Fort., 29 Jan 76, at 22 (issue no.3).

294. Francfort \& Woo, "Lifeline and Incremental Cost Residential Electric Rates," 99 Pub. Util. Fort., $17 \mathrm{Feb} 77$, at 15 (issue no.4).

295. Id. 
296. Id. at 16 .

297. I. Stelzer, supra note 96 , at $\mathrm{C}-3,11$.

298. Id. at $\mathrm{C}-5$.

299. Id. at $\mathrm{C}-1$.

300. Consol. Edison Co. of N.Y., 85 P.U.R.3d 276, 296-97 (N.Y. Pub. Serv. Comm'n 1970).

301. Pennsylvania Pub. Util. Comm'n v. Philadelphia Elec. Co., 91 P.U.R.3d 321, 372 (Penn. Pub. Util. Comm'n 1971).

302. Id. at 375 .

303. Re Pub. Serv. Co. of N.H., 95 P.U.R.3d 40 1, 448 (N.H. Pub. Util. Comm'n 1972).

304. Id. at $448-49$.

305. Re Rate Concessions to Poor Persons and Senior Citizens, 14 P.U.R.4th 87, 92 (Oregon Pub. Util. Comm'n 1976)

306. Id. at 91 .

307. Id. at 95 .

308. Cal. Pub. Util. Code $\$ 739$ (West 1975 \& Supp. 1978).

309. Id. at $\$ 739(a)$.

310. Id. at $\$ 739(\mathrm{~b})$.

311. Re California - Pacific Util. Co., 17 P.U.R.4th 256, 268 (Calif. Pub. Util. Comm'n 1976).

312. Re Montana - Dakota Util. Co., 21 P.U.R.4th 1, 29-30 (South Dakota Pub. Util. Comm'n 1977).

313. Id. But see the arguments opposing social ratemaking in Ranniger, "Electric RatesWhere We Have Been, Where We Are Going," 99 Pub. Util. Fort., 12 May 77, at 29 (issue no. 10). Ranniger states that the problems encountered in the various lifeline proposals are as follows:

(1) The benefits of lifeline proposals cannot administratively be isolated to the poor or elderly.

(2) Lif eline rates fail to benefit a significant proportion of the poor due to their unique situations or patterns of consumption.

(3) Lif eline proposals, instead of conserving energy, may actually stimulate greater consumption since most of the schemes reduce bills for customers who use considerably more than the minimum.

(4) Redistribution of inculie is more properly a government function than a utility function. 
(5) Lifeline rates run counter to one of the current emphases in rate design, that of covering all costs incurred in producing and delivering energy.

(6) Proposals for recovering lost revenues as a result of lowering rates for minimum necessary use are fraught with difficulties and inequities.

Id. at 33.

314. P. Garfield \& W. Lovejoy, supra note 21 , at 156 .

315. Public Service Co. of Colorado Residential Demand Service, Schedule RD-1 (Effective 23 Aug 78). This rate is optional and applicable to residential service where electric heating is the principal source of heat or the primary backup source to another form of heat. It contains the following charges:

Demand Chargeı

First kilowatt of billing demand or less

All over $1 \mathrm{~kW}$ of billing demand, per $\mathrm{kW}$

Energy Charge:

All kilowatt hours used, per kWh

.01001

316. The average watt-hour meter for single phuse serviee custs approximately $\$ 30$ to $\$ 22$. Rate Design Study, supra note 152 , at 68,72 .

317. A meter capable of measuring a customer's peak demand in $\mathrm{kW}$ and energy consuption in $\mathrm{kWh}$ for single phase service costs approximately $\$ 70$. Id.

318. P. Garfield \& W. Lovejoy, supra note 21 , at 156 .

319. Id. at 157. Regarding a description of load factor and how to calculate it, see text accompanying notes $227-28$ supra.

320. Id.; Berlin, supra note 97, at 17.

321. Re Customers of Cambridge Electric Light Co., F.U.R. 1933 D, 113, 117-18 (Mass. Dept. of Pub. Util. 1933).

322. Antioch Milling Co. v. Public Service Co. of Northern Illinois, 4 Ill.2d 200, 123 N.E.2d 302, 306 (1954).

323. Re Pub. Serv. Co. of N.H., 27 P.U.R.3d 113, 126 (N.H. Pub. Serv. Comm'n 1959).

324. See Berlin, supra note 97 , at 18-21.

325. Id. at 19.

326. Id. at 18 .

327. See Mann, supra note 286 , at 31 .

328. Peak-load pricing is discussed generally in Berlin, supra note 97, at 29-51; Grainger, "A Practical Approach to Peak-Load Pricing," 98 Pub. Util. Fort., 9 Sept 76, at 19 (issue no. 6); Mann, supra note 286, at 31-32; Task Force No. 1, "The Development of a Framework for Peak-Load Pricing Appropriate to the United States" (1.3) 1-74 in Analysis Of Various Pricing Approaches: Topic I (Feb. 1977) (prepared for the 
Electric Utility Rate Design Study); Teed, "A Practitioner Looks at Peak-Load Pricing," 97 Pub. Util. Fort., 29 Jan 76, at 26 (issue no. 3); Wenders, "The. Misapplication of the Theory of Peak-Load Pricing to the Electric Utility Industry," 96 Pub. Util. Fort., 4 Dec 75 , at 22 (issue no. 12). See also Huntington, supra note $2 \overline{2 \text {, at }}$ 723-25. A shift from traditional pricing policies and rates to peak-load pricing was strongly recommended in Energy Policy Project of the Ford Foundation, A Time to Choose 257-60, 328, 340 (1974).

329. Mann, supra note 286 , at 32 .

330. Id.

331. An illustrative residential rate based on marginal costs was developed by the National Economic Research Associates, Inc., for an eastern utility as part of the Electric Utility Rate Design Study. The resulting structure appeared as follows:

Peak Season (Summer)

$\begin{array}{ll}\text { Customer Charge } & \\ \text { Demand Charge } & \$ 9.70 \\ \text { Peak Hours } & \\ \text { Energy Charge } & \$ 5.95 \text { per } \mathrm{kW} \\ \text { Peak Hours } & \\ \text { Off-peak Hours } & \$ 0.0215 \text { per } \mathrm{kWh} \\ & \$ 0.0120 \text { per } \mathrm{kWh}\end{array}$

Secondary-peak Season (Winter)

Customer Charge

$\$ 9.70$

Demand Charge Peak Hours

$\$ 1.41$ per $\mathrm{kW}$

Energy Charge

Peak Hours

$\$ 0.0215$ per $\mathrm{kWh}$

Off-peak Hours

$\$ 0.0120$ per $\mathrm{kWh}$

332. Berlin, supra note 97 , at $29-30,46$; Brancato, supra note 262 , at 80 ; Huntington, supra note 22 , at 723 .

333. Berlin, supra note 97 , at 30 ; Huntington, supra note 22 , at 724 .

334. Berlin, supra note 87 , at 46 ; Mann, supra note 327 , at 32 .

335. See Huntington, supra note 22 , at 735 .

336. See text accompanying notes $235-36$ supra.

337. Huntington, supra note 22 , at $722-23$; 1 A. Kahn, supra note 21 , at $69-70$; Sherry, "Cutting the Marginalists' Gordian Knot," 99 Pub. Util. Fort., 17 Feb 77, at 21 (issue no. 4). The problem of second best, where substitute goods or services are priced below marginal costs is considered in Huntington, supra note 22, at 747-49 and $1 \mathrm{~A}$. Kahn, supra note 21 , at 195-99.

338. Berlin, supra note 97, at 127, 132 (Appendix B, Some Mathematics of Public Utility Pricing: A Synthesis of Marginal Cost Pricing, Regulatory Constraints, AverchJohnson Bias, and Peak Load Pricing and Block Pricing) also printed as Cicchetti \& 
Jurewitz, Public Utility Pricing: A Synthesis of Marginal Cost, Regulatory Constraints, Averch - Johnson Bias, Peak-Load and Block Pricing, Cicchetti \& Jurewitz, supra note 257, at 89, 94 . See also Aman \& Howard, supra note 276, at 1094-95; Huntington, supra note 22, at 738-41.

339. Berlin, supra note 97 at $40-43$; Hunting ton, supra note 22 , at 727 .

340. Huntington, supra note 22, at 725-30; Task Force No. 1, supra note 328 , at 52-53.

341. Berlin, supra note 97 , at 43-44; Task Force No. 1, supra note 328 , at 53.

342. Berlin, supra note 97 , at 45-46. Meter availability for small volume commercial and residential customers is a significant problem. See Cicchetti, "The Design of Electricity Tariffs," 96 Pub. Util. Fort., Aug. 28, 1975, at 25, 31 (issue no. 5). Depending on the particular TOD rate structure employed, meters designed to measure $\mathrm{kWh}$ consumption at different periods or a combinatinn of off-and on-peak demand and energy consumption cost from $\$ 44$ to $\$ 140$ for single phase service. Rate Design Study, supra note 152, at 68-72. More sophisticated designs can run upwards of $\$ 300$. Id.

343. See Huntington, supra note 22 , at 748 .

344. See generally Aman \& Howard, supra note 276, at 1095-1100; Huntington, supra note 22 , at $738-46$.

345. A form of price discrimination occurs when long-run incremental cost (LRIC) rates are adjusted according to the inverse price elasticity rule and also when demand costs are allocated on this basis because cost-of-service is not a guiding concern. However, such practices may be deemed just and reasonable as being consistent with the value-of-service concept in ratemaking. See text accompanying notes 132-58 supra.

346. See Frank, "Lifeline Proposals and Economic Efficiency Requirements," 99 Pub. Util. Fort., 26 May 77, at 11 (issue no. 11).

347. Berlin, supra note 97, at 40-43, citing R. Turvey, Optimal Pricing and Investment in Electric Supply (1968).

348. In eight states, commissions have ordered individual utilities to study the feasibility of TOD rates. TOD rate experiments have been undertaken in 17 states; 10 of the states received FEA funding, and in the remaining ?, the exporiments woro cither ordered by the commissions or initiated by the utilities. Testimnny of $\mathrm{Dr}$. Irwin M, Stelzer, Generic Hearings, Case No. 5693 (Colo. Pub. Util. Comm'n, 19-20 Jan 78) (request for investigation as ordered 13 July 76, Decision no. 89068).

349. See generally Nissel, "The European Experience with Peak-load Pricing," 99 Pub. Util Fort., 17 Mar 77, at 13 (issue no. 6) and sources cited therein.

350. See Ranniger, supra note 313 , at 32 .

351. For a discussion of the legality of marginal cost pricing light of claims of undue discrimination, see generally Kadane, "The Legality of Marginal Cost Pricing for Utility Service," 5 Hofstra L. Rev. 755 (1977).

352. 404 N.Y.S.2d 899 (App. Div. 1978). 
353. Re Rate Design for Elec. Corp., 15 P.U.R.4th 434, 453 (N.Y. Pub. Serv. Comm'n 1976).

354. Long Island Lighting Co., Case 26887 (N.Y. Pub. Serv. Comm'n, filed August 1975).

355. Long Island Lighting Co., Case 26887, 16 N.Y.P.S.C. 1071, Opinion No. 76-26 (N.Y. Pub. Serv. Comm'n 1976).

356. Id. at 1076, Opinion No. 76-26 at 7.

357. Id.

358. Id. at 1088-89, Opinion No. 76-26 at 30.

359. Id. at 1089-90, Opinion No. 76-26 at 32-33.

360. 404 N.Y.S. $2 d$ at 902 .

361. Id.

362. Brief for Appellant Pub. Serv. Comm'n at 24-26 (August 1978).

363. 5 P.U.R. 4th 28 (Wis. Pub. Serv. Comm'n 1974). For an indepth discussion of the case, see generally Brancato, supra note 262 at 72-76; Cudahy \& Malko, "Electric Peak-Load Pricing: Madison Gas and Beyond," 47 Wis. L. Rev. 47 (1976); Huntington, supra note 22 at 749-50; Note, "Reform of Electricity Pricing in the United States," 25 Buff. L. Rev. 183, 196-209 (1975).

364. 5 P.U.R. 4 th at 34 .

365. Id. at 35 .

366. Id. at $36-37$.

367. Id. at 40. The residential rates before and after the Madison Gas decision were:

\begin{tabular}{|c|c|c|c|}
\hline & & After & \\
\hline & Before & Winter & Summer \\
\hline Fixed Charge & $\$ 0.75$ & $\$ 1.50$ & $\$ 1.50$ \\
\hline First $100 \mathrm{kWh}$ & $0.0285 / \mathrm{kWh}$ & $0.0250 / \mathrm{kWh}$ & $0.0250 / \mathrm{kWh}$ \\
\hline Next $400 \mathrm{kWh}$ & $0.0203 / \mathrm{kWh}$ & $0.0220 / \mathrm{kWh}$ & $0.0220 / \mathrm{kWh}$ \\
\hline Next $500 \mathrm{kWh}$ & $0.0203 / \mathrm{kWh}$ & $0.0220 / \mathrm{kWh}$ & $0.0220 / \mathrm{kWh}$ \\
\hline Next $500 \mathrm{kWh}$ & $0.0156 / \mathrm{kWh}$ & $0.0150 / \mathrm{kWh}$ & $0.0220 / \mathrm{kWh}$ \\
\hline Over $1,500 \mathrm{kWh}$ & $0.0156 / \mathrm{kWh}$ & $0.0150 / \mathrm{kWh}$ & $0.0220 / \mathrm{kWh}$ \\
\hline
\end{tabular}

Cudahy \& Malko, supra note 363 , at 73 n. 73 .

368. See I. Stelzer, supra note 96 , at Table C cols. 7-8.

369. Testimony of Dr. Stelzer, supra note 348 , at 7 .

370. I. Stelzer, supra note 96 , at $\mathrm{C}-2$.

371. Findings of Fact and Order Establishing Temporary Experimental Rates, Docket 6690-ER-5 (Wis. Pub. Serv. Comm'n 1977). 
372. Findings of Fact and Interim Order, Dockets 6630-ER-2, 6630-ER-5 at 10-11 (Wis. Pub. Serv. Comm'n 1978).

373. See id. app. D. at 3.

374. Findings of Fact and Order, Dockets 6630-ER-2, 6630-ER-5 (Wis. Pub. Serv. Comm'n 1978).

375. Id. at 26 .

376. Rate Design Study, supra note 152 , at 39 .

377. Bezdek, supra note 15, at 375 , Dean \& Miller, supra note 15, at 343 ; N. Dean \& A. Miller, supra note 15, at 50075, Legal Barriers to Solar, supra note 15, at 97 .

378. Rate Design Study, supra note 15\%, at 3ُ9่.

379. Id.

380. Feldman and Anderson, supra note 8, at 155.

381. Id.

382. 77 S.W.2d 1091 (Tex. Ct. App. 1934).

383. Id. at 1094.

384. Id.

385. Mlinois Coal Operators Ass'n v. The Peoples Gas Light \& Coke Co., 7 P.U.R. (n.s.) 403, 405 (Ill. Commerce Comm'n 1934).

386. Id. at $416-17$.

387. Demand and demand/energy rates are discussed in the text accompanying notes 314-27 supra.

388. In Re Proposed Increased Rates and Charges Contained in Tariff Revisions filed by Pub. Serv. Co. of Colo., Decision No. 87640 (Colo. Pub. Util. Comm'n, 21 Oct 75).

389. Testimony of James H. Ranniger, Manager of Rates and Regulations, Pub. Serv. Co. of Colo., Investigation and Suspension Docket No. 935, Exhibit No. 36 at 14 (22 Sept 75).

390. Testimony of Dr. Ernst Habict, Jr. and Dr. William Vickrey for the Environmental Defense Fund before the Colo Pub. Util. Comm'n. Investigation and Suspension Docket No. 935 (22 Sept 75).

391. Home Builders Ass'n of Metropolitan Denver v. Pub. Serv. Co. of Colo., Case 5675 (Colo. pub. Util. Comm'n, 5 Apr 76).

392. In Re Investigation of Residential Demand Rates of Pub. Serv. Co. of Colo., Case No. 5685, Decision No. 88822 (Colo. Pub. Util. Comm'n, 25 May 76). 
393. Testimony of W. J. Gillen and D. J. Frey for the Environmental Defense Fund and the Architect's Group, Home Builders Ass'n of Metropolitan Denver v. Pub. Serv. Co. of Colo., Cases No. 5675, 5685, Decision No. 89573, Exhibits 25, 26 (Colo. Pub. Util. Comm'n, 26 Oct 76).

394. Cases No. 5675,5685 , Decision No. 89573 at 6 .

395. Pub. Serv. Co. of Colo., Residential Demand Service, Schedule RD-1 (Effective 23 Aug 78). The rate is applicable to overhead residential service where electric heating is the principle source of heat or the primary backup source to another form of heat. The applicable charges are:

Demand Charge:

lst $\mathrm{kW}$ of Billing Demand or Less

$\$ 7.50$

All over $1 \mathrm{~kW}$ of Billing Demand

$\$ 3.20$ per $\mathrm{kWh}$

Energy Charge:

All $\mathrm{kWh}$

$\$ 0.01001$ per $\mathrm{kWh}$

396. Pub. Serv. Co. of Colo., Residential Heating Service, Schedule RH-1 (Effective 23 Aug 78). The Rate is applicable to overhead residential service where electric heating is the principle source of heat or the primary backup source to another form of heat. The applicable charges are:

First $200 \mathrm{kWh}$ or less

$\$ 9.46$

Next $800 \mathrm{kWh}$

0.03995 per $\mathrm{kWh}$

All over $1,000 \mathrm{kWh}$

0.02772 per $\mathrm{kWh}$

397. Pub. Serv. Co. of Colo., General Residential Service, Schedule R-1 (Effective 23 Aug 78). The rate is applicable to overhead residential service except where electric heating is the principal source of heat or the primary backup source of heat to another form of heat. The applicable charges are:

First $30 \mathrm{kWh}$ or less

$\$ 1.72$

Next $70 \mathrm{kWh}$

$\$ 0.04317$ per $\mathrm{kWh}$

Next $900 \mathrm{kWh}$

All nver $1,0 n \cap \mathrm{kWh}$

$\$ 0.03467$ per $\mathrm{kWh}$

$\$ 0.02409$ per $\mathrm{kWh}$

398. The cost comparison has been liberally adapted from that provided in Mills, "Demand Electric Rates: A New Problem \& Challenge for Solar Heating," 19 Am. Soc'y Heating, Refrig. \& Air Conditioning Eng. J., January 1977, at 42 (issue no. 1). The rates used in the comparison have been updated to those in effect during the fall of 1978 .

399. Btu (British thermal unit) is a unit of work or energy and is defined as the quantity of heat required to raise the temperature of $1 \mathrm{lb}$ (mass) of water from $63^{\circ} \mathrm{F}$ to $64^{\circ} \mathrm{F} .1 \mathrm{Btu}=778.3 \mathrm{ft} \mathrm{lb}=1,055 \mathrm{~J}=2.931 \times 10^{-4} \mathrm{kWh}$.

400. Mills, supra note 398 , at 42 .

401. Id.

402. Mountain Fuel Supply Co., Firm Standby Service, Schedule F-3 (Effective 5 Apr 78). The rate 'is applicable to natural gas service for residential, commercial, or industrial use at one point of delivery where such use acts as a standby to the use 
of other fuels or other forms of energy. It is also applicable to use which supplements the use of other fuels or energy during the winter season. The applicable charges are:

Initial Charge: $\quad \$ 97.90$ per year payable in monthly installments of $\$ 8.16$ per month.

Demand Charge: $\quad \$ 39.44$ per year per $1,000 \mathrm{ft}^{3}$ or fraction thereof of maximum daily input rating of gas-fired equipment payable in equal monthly installments.

Commodity

Charge:

All gas at $\$ 1.212$ per $1,000 \mathrm{ft}^{3}$.

403. In subsequent communications, company representatives indicated that the standby service rate was not intended to be applicable to residential solar customers.

404. Mountain Fuel Supply Co., General Service, Schedule GS-l (Effective 5 Apr 78). The rate is applicable to natural gas service for residential, commercial, or industrial uses at one point of delivery and includes heating of large huildings not eligible for high-load factor or interruptible rates. The charges applicable are:

Monthly Minimum

Continuous Service Credit

First $200 \mathrm{ft}^{3}$

Next $1,800 \mathrm{ft}^{3}$

Next $3,000 \mathrm{ft}^{3}$

Next 45,000 $\mathrm{ft}^{3}$

Over $50,000 \mathrm{ft}^{3}$
(November - May)

$\$ 4.30$

$0.197004 / 100 \mathrm{ft}^{3}$

$0.169399 / 100 \mathrm{ft}^{3}$

$0.140548 / 100 \mathrm{ft}^{3}$

$0.139413 / 100 \mathrm{ft}^{3}$
$\$ 4.30$ (Winter Only)

$\$ 1.00$ (Winter Only)

(June - October)

$\$ 0.140548 / 100 \mathrm{ft}^{3}$

$0.140548 / 100 \mathrm{ft}^{3}$

$0.140548 / 100 \mathrm{ft}^{3}$

$0.129524 / 100 \mathrm{ft}^{3}$

$0.128422 / 100 \mathrm{ft}^{3}$

405. Columbia, Mo., Ordinance 7563 (Sept. 6, 1977).

406. Id. at exhibit A.

407. The Columbia, Mo., residential service rate applies to all customers where service is supplied to a residential dwelling unit. The monthly minimum charges are:

First $40 \mathrm{kWh}$

Next $60 \mathrm{kWh}$

Next $900 \mathrm{kWh}$

Over $1,000 \mathrm{kWh}$
$\$ 2.97$

$\$ 0.07353$ per $\mathrm{kWh}$

$\$ 0.03510$ per $\mathrm{kWh}$

$\$ 0.02878$ per $\mathrm{kWh}$

Except where the customer has permanently installed in a domestic area a minimum of five $\mathrm{kW}$ of utility approved electric space heating equipment, which is the sole source of comfort space heating, the rate shall be $\$ 0.0283$ per $\mathrm{kWh}$ for all $\mathrm{kWh}$ over $850 \mathrm{kWh}$ for seven consecutive months beginning in November. Columbia, Mo., Rev. Ordinance ch. 15, art. V, $\$ 15.550$ (1978).

408. The additional advance service deposit and prohibition of application of promotional all-electric rates imposed upon solar customers were removed by the city early in 1978.

409. Southwestern Tel. \& Tel. Co. v. Danaher, 238 U.S. 482, 490 (1915); Union Light, Heat, \& Power Co. v. Mulligan, 197 S.W. 1081. In Union, the Kentucky Ct. of Appeals, while recognizing the general rule, further held that the rule permitting a 
utility to require the deposit does not permit it to hold the consumer's money without paying interest thereon. Id. at 1085 .

410. Wickenburg v. Sabin, 68 Ariz. 75, 200 P.2d 342, 344 (1948). Accord, Barriger v. Louisville Gas \& Elec. Co., 196 Ky. 268, 244 S.W. 690 (1922).

411. See Mo. Ann. Stat. $\$ \S 386.020,386.250$ (Vernon Supp. 1978).

412. Booz, Allen \& Hamilton, Inc., The Effectiveness of Solar Energy Incentives at the State and Local Level, ch. VI at 1-9 (March 1976) (prepared for the Federal Energy Administration, Office of Syn fuels, Solar, and Geothermal Energy, FEA Contract No. CO-05-50272-00) [hereinafter cited as BAH Report].

413. Id. ch. VI at $3-4$.

414. Id. ch. VI at $4-5$.

415. Id. ch. VI at 5.

416. Id. ch. VI at 6.

417. Id. ch. VI at 7-8.

418. Id. ch. VI at 8-9.

419. Id. ch. VI at 9.

420. S. Feldman \& B. Anderson, Utility Pricing and Solar Energy Design 87 (Sept. 1976) (prepared for the National Science Foundation, Grant No. APR-75-18006) [hereinafter cited as Utility Pricing/Solar Designl, Feldman \& Anderson, supra note 8, at 51, 148-49.

421. Dickson, Eichen, \& Feldman, "Solar Energy and U.S. Public Utilities," S. Energy Policy, Sept. 1977, at 195, 202-03 (issue no. 3); Feldman \& Anderson, supra note 8, at 55 .

422. See Dickson, Eichen, \& Feldman, supra note 421, at 203, Table 5; Feldman and Anderson, supra note 8, at 56 .

423. H. Lorsch, Implications of Residential Solar Space Conditioning on Electric Utilities ch. 9 at 1 (Dec. 1976) (prepared by the Franklin Institute Research Laboratories for the National Science Foundation, Contract No. NSF-C1033 (AER-75-18270).

424. See id. ch. 6 at 10-15; Utility Pricing/Solar Design, supra note 420, at 118; Feldman \& Anderson, supra note 8 , at 58 .

425. Koger, "Regulatory Constraints on Solar Energy and Thermal Storage Installations," 101 Pub. Util. Fort., 19 Jan 78, at 9, 11 (issue no. 2).

426. Id.

427. Utility Pricing/Solar Design, supra note 420 , at 118-19. 
428. H. Lorsch, supra note 423 , ch. 8 at 15 .

429. Jones, supra note 1 , ch. IV at 16-18; Koger, supra note 425 , at 11 . See generally Feldman \& Anderson, "Financial Incentives for the Adoption of Solar Energy Design: Peak-Laad Pricing of Back-Up Systems," 17 Solar Energy 339 (April 1975) [hereinafter cited as Financial Incentive]. See also E. Habicht, "Electric Utilities and Solar Energy: Competition, Ownership, Subsidies and Prices" in Federal Trade Commission, The Solar Market: Proceedings of the Symposium on Competition in the Solar Energy Industry 229, 231-34 (June 1978) (Sponsored by the FTC's Bureau of Competition on Dec. 15-16, 1977); S. Anderson, "Economics of Solar Space Conditioning Systems: Electric Rates and Other Institutional Barriers" in K. Hillhouse, Legal and Institutional Perspectives on Solar Energy. in Colorado at App. B (Nov. 1977) (prepared for the National Science Foundation, Grant No. APR 75-18247).

430. Jones, supra note 1 , ch. IV at 15 .

431. H. Lorsch, supra note 423 , ch. 8 at 18 .

432. Findings of Fact and Order, Dockets 6630-ER-2, 6630-ER-5 at 19-20 (Wis. Pub. Serv. Comm'n 1978).

433. Id. at 20 .

434. Dickson, Eichen, \& Feldman, supra note 421 , at 197.

435. Dickson, Eichen, and Feldman provide a tabulation of work on the utility and solar energy interface as well as a status report of projects underway through the National Science Foundation (NSF), the Energy Research and Development Administration (ERDA), the Electric Power Research Institute (EPRI), and others. Id. at 198-y9, app. '2 at 2U4-1U. See also Electrlc Power Reseurch Instilute, Electric Utility Solar Energy Activities 1976 Survey (January 1977) (EPRI ER-32 1SR Special Report) 3 EPRI Journal, March 1978 (issue no. 2, Solar Technology Today Special Report); Feldman and Anderson, supra note 8, at 17-44.

436. Dickson, Eichen, \& Feldman, supra note 421, at 196. Contra, D. Spencer, "Solar Energy: A View from an Electric Utility Standpoint" 10 (presented at the American Power Conference, Chicago, Ill., 21-23 Apr 75)(Solar systems will not result in capacity savings).

437. See generally OTA Report, supra note 3 , at 151-59.

438. Id. at 151 .

439. Id.

440. Id. at $156-57$

441. Jones, supra note 1 , ch. IV at 2-3.

442. Feldman and Anderson, supra note 8, at 50 .

443. BAH Report, supra note 412 , ch. I at 5 , ch. VI at 2 . 
444. H. Lorsch, supra note 423 , ch. 1 at $3-6$.

445. See Utility Pricing/Solar Design, supra note 420.

446. Id. at 78; Dickson, Eichen \& Feldman, supra note 421, at 201; Feldman and Anderson, supra note 8 , at 51 .

447. See Utility Pricing/Solar Design, supra note 420 , at 83,85 .

448. Id. at 97,99 .

449. Id. app. $H$ at 7, app. J at 6 .

450. Id. at 117. The Feldman and Anderson investigation was continued to systematically evaluate an optimum peak mitigating solar building design. See S.L. Feldman, B. Anderson, R. Wirtshafter, M. Abrash, C. Carter, P. Sullivan, J. Kohler, J. Breeze, The Impact of Active and Passive Solar Building Designs on Utility Peak Loads (Sept. 30, 1977) (interim report to the Energy Research and Development Administration, Division of Solar Energy, Contract No. EG-77-G-01-4029).

451. G. Swetnam, F. Eldridge, \& D. Jardine, Energy Rate Initiatives Study of the Interface Between Solar and Wind Energy Systems and Electric Utilities 52 (March 1977) (prepared for the Federal Energy Administration Office of Synfuels, Solar, and Geothermal Energy by the MITRE Corp., FEA Contract No. P05-77-4242-0).

452. Id. at 51, citing C. Peterson, "Use of Off-Peak Electric Energy to Alleviate PeakLoad Problems of Solar Space and Water Heating Systems" (unpublished).

453. See generally EPRI, "Solar Homes: The Winning Combination," 3 EPRI Journal, Mar. 1978, at 6-13 (issue no. 2); S. Robinson, "Solar and Utilities: An Example in Cooperation," Solar Age, Dec. 1978, at 20-23.

454. Arthur D. Little, Inc., System Definition Study: Solar Heating and Cooling Residential Project (July 1977) (prepared by EPRI, Report No. ER-467-SY, Summary Report); Arthur D. Little, Inc., System Definition Study-Phase 1: Individual Load Center, Solar Heating and Cooling Residential Project (Dec. 1977) (prepared for EPRI, Report No. ER-594, Final Report).

455. D. Jardine \& D. Jones, Phoenix House: Solar-Assisted Heat Pump System Evaluation (Mar. 1978) (prepared by Kaman Sciences Corp. for EPRI, Report No. ER-712, Final Report).

456. Id. ch. 3 at 1 .

457. 1 C. Cretcher \& W. Melton, SHACOB: Requirements Definition and Impact Analysis (June 1978) (prepared by the Aerospace Corp. for EPRI, Report ER-808, Final Report).

458. 2 Id.

459. 3 Id.

460. 4 Id. 
461. 1 Id. at 84.

462. E.g., State ex rel. North Carolina Util. Comm'n v. City of Wilson, 252 N.C. 640,114 S.E.2d 786, 791 (1960); F.\&R. Lazarus \& Co. v. Pub. Util. Comm'n, 162 Ohio St. 223, 122 N.E.2d 783, 786, 7 P.U.R.3d 313, 317 (1954). For general discussions of rate discrimination, see Bezdek, supra note 15, at 362-68, 370-77; Dean and Miller, supra note 15, at 333-37; N. Dean and A. Miller, supra note 15 , at 50071-73, 5007377; Legal Barriers to Solar, supra note 15, at $8 y-y z, y 4-\dot{y} 8 ; 1 A$. Prlest, supru nule 21 , at $285-326$.

463. Citizens Util. Co. v. Ill. Commerce Comm'n, 50 nl.2d 35, 276 N.E.2d 330, 336 (1971).

464. Hicks v. City of Monroe Util. Comm'n, 237 La. 848, 112 So.2d 635, 644, 29 P.U.R.3d 275,285 (1959).

465. See, e.g., Louisiana v. FPC, 503 F.2d 844 (5th Cir. 1974) wherein the court stated that the "FPC could assist the court if it would define what it believes is meant by the phrases undue preference or advantage and undue prejudice or disadvantage ..." Id. at 864. See generally Permian Basin Area Rate Cases, 390 U.S. 747, 790-92 (1968); 1 A. Priest, supra note 21, at 288-89.

466. 246 S.W.2d 622, 624 (1952).

467. Unlike many other states, Louisiana has no statewide statute that prohibits unreasonable discrimination in utility ratemaking. The courts in Louisiana have, however, adopted the general rule that a utility's rate structure must be nondiscriminatory. State ex rel. Guste v. Council of New Orleans, 309 So.2d 290, 294, 9 P.U.R. 4th 353, 357 (La. 1975), cert. denied, Craft v. Louisiana, 423 U.S. 1075 (1976).

468. N.Y. Pub. Serv. Law $\$ 65.2$ (McKinney 1955 ).

469. Id. at $\$ 6 b .3$.

470. Id. at $\$ 65.5$.

471. Id. at $\$ 66.14$.

472. Hayes v. Niagara Mohawk Power Corp., 63 Misc.2d 581, 312 N.Y.S.2d 436, 437-38 (Sup. Ct. 1970), rev'd on other grounds, 35 App. Div.2d 1072, 316 N.Y.S.2d 520 (1970), aff'd, 30 N.Y.2d 579, 330 N.Y.S.2d 785 (1972).

473. Columbia Gas of N.Y., Inc. v. N.Y. State Elec. \& Gas Corp., 33 App. Div.2d 1057, 307 N.Y.S.2d 313 (App. Div. 1970), aff'd, 28 N.Y.2d 117, 320 N.Y.S.2d 57, 268 N.E.2d $790(1971)$.

474. Id. at 316.

475. 50 App. Div.2d 338, 377 N.Y.S.2d 671 (App. Div. 1975), aff'd, 40 N.Y.2d 1047, 392 N.Y.S.2d 239, 360 N.E.2d 918 (1976).

476. 377 N.Y.S.2d at 674. 
477. 40 N.Y.2d at 1048,392 N.Y.S.2d at 240,360 N.E.2d at 918-19.

478. Id., 392 N.Y.S.2d at 240,360 N.E.2d at 919.

479. Wis. Stat. Ann. $\$ 196.60$ (West Supp. 1978).

480. Wis. Stat. Ann. $\$ 196.62$ (West 1957).

481. Id. at $\$ 196.02(2)$.

482. President and Trustees of Kilbourn City v. So. Wis. Power Co., 149 Wis. 168, 135 N.W. 499, 504 (1912).

483. Re City of Plymouth, 52 P.U.R. (n.s.) 521,522 (Wis. Pub. Serv. Comm'n 1943).

484. City of Boscobel v. Wis. Power and Light Co., 52 P.U.R.3d 264, 265 (Wis. Pub. Serv. Comm'n 1964).

485. Colo. Rev. Stat. $\$ 40-3-106$ (1973).

486. Lamar Alfalfa Milling Co. v. Lamar, Case No. 1597, Decision No. 8549 (Colo. Pub. Util. Comm'n 1936).

487. Id.

488. School Dist. No. 47 v. Lakewood Sanitation Dist., 68 P.U.R. (n.s.) 385, 393 (Colo. Pub. Util. Comm'n 1947).

489. 1 A. Priest, supra note 21 , at 288 .

490. See, e.g., Pittsburgh v. Pub. Util. Comm'n, 78 A.2d 35, 38 (Penn. 1951). See generally l A. Priest, supra noto 21, at 300-03, 30405.

491. 1 A. Priest, supra note 21 , at 300-03.

492. E.g., General Motors Corp. v. Pub. Util. Comm'n 47 Ohio St.2d 58, 351 N.E.2d 183, 189 (1976); Chicago Bd. of Trade v. United States, 223 F.2d 348, 354, 9 P.U.R.3d 475, 482 (D.C. Cir. 1955).

493. Smith v. Southern Union Gas Co., 58 N.M. 197, 269 P.2d 745, 747-48 (1954); Ten Ten Lincoln Place, Inc. v. Consolidated Edison Co., 273 App. Div. 903, 77 N.Y.S.2d 168, 168 (App. Div. 1948).

494. See, e.g., Smith v. Pub. Serv. Comm'n, 351 S.W.2d 768, 772, 43 P.U.R.3d 43, 47 (Mont. 1961). See also 1 A. Priest, supra note 21, at 324-25.

495. Hicks v. City of Monroe Util. Comm'n, 237 L\&. 848, 112 So.2d 635, 644, 29 P.U.R.3d 275,285 (1959).

496. Jager v. State, 537 P.2d 1100, 1109 (Alaska 1975).

497. E.g., Cleveland Elec. Illuminating Co. v. Pub. Util. Comm'n, 42 Ohio St.2d 403, 330 N.E.2d 1, 18-19 (1975); Penn. Pub. Util. Comm'n v. Metropolitan Edison Co., 86 P.U.R.3d 163, 195-96 (Penn. Pub. Util. Comm'n 1970). 
498. Ill. Ann. Stat. ch. $1112 / 3, \S 38$ (Smith - Hurd 1966). The statute provides in part that:

No public utility shall, as to rates or other charges, services, facilities, or in other respect, make or grant any preference or advantage to any corporation or person or subject any corporation or person to any prejudice or disadvantage. No public utility shall establish or maintain any unreasonable difference as to rates or other charges, services, facilities, or in any other respect, either as between localities or as between classes of service.

499. Ill. Ann. Stat. ch. $1112 / 3 \$ 38$ (Smith - Hurd Supp. 1978) (amended by P.A. 80-431, $\$ 1$, effective 30 Aug 77) (emphasis added).

500. Promotional activities for the purpose of stimulating business have been declared nondiscriminatory and upheld in many jurisdictions. See, e.g., Re Promotional Practices of Elec. and Gas Util., 65 P.U.R.3d 405 (Conn. Pub. Util. Comm'n 1966); Re Delaware Power \& Light Co., 56 P.U.R.3d 1 (Del. Pub. Serv. Comm'n 1964); Rossi v. Garton, 88 N.J. Super. 233, 211 A.2d 806, 60 P.U.R.3d 210 (N.J. Super. Ct. App. Div. 1965); Gifford v. Central Maine Power Co., 217 A.2d 200, 63 P.U.R.3d 208 (Me. 1966); In re City Ice \& Fuel Co., 260 App. Div. 537, 23 N.Y.S.2d 376, 37 P.U.R. (n.s.) 218 (App. Div. 1940); Re Promotional Activities by Gas and Elec. Corps., 68 P.U.R.3d 162 (N.Y. Pub. Serv. Comm'n 1967); Watkins v. Atlantic City Electric Co., 67 P.U.R.3d 483 (N.J. Bd. of Pub. Util. Comm'rs 1967); Virginia State Corp. Comm'n v. Appalachian Power Co., 65 P.U.R.3d 283 (Va. Corp. Comm'n 1966). See also State v. Oklahoma Gas and Elec. Co., 536 P.2d 887, 9 P.U.R. 4th 369 (Okla. Sup. Ct. 1975).

501. 88 N.J. Super. 233, 236, 211 A.2d 806, 808, 60 P.U.R.3d 210, 212, (N.J. Super. Ct. App. Div. 1965).

502. Id.

503. 217 A.2d 200, 63 P.U.R.3d 208 (Me. 1966).

504. Id. at 203, 63 P.U.R.3d at 212.

505. 536 P.2d 887, 896, 9 P.U.R.4th 369, 380 (Okla. Sup. Ct. 1975).

506. See, e.g., McBride \& Son Builders, Inc. v. Unlon Electrle Co., 926 3.W.2d 310 (Me. Sup. Ct. 1975); Re Southwest Gas Corp., 61 P.U.R.3d 467 (Cal. Pub. Util. Comm'n 1965); Re Carolina Power \& Light Co., 52 P.U.R.3d 561 (N.C. Util. Comm'n 1964); Re Portland General Elec. Co., 67 P.U.R.3d 417 (Ore. Pub. Util. Comm'r 1967); Re Duke Power Co., 54 P.U.R.3d 574 (N.C. Util. Comm'n 1964); Suburban Md. Home Builders Ass'n v. Potomac Elec. Power Co., 72 P.U.R.3d 282 (Md. Pub. Serv. Comm'n 1968).

507. 72 P.U.R.3d 282 (Md. Pub. Serv. Comm'n 1968).

508. Id. at 289.

509. McBride \& Son Builders, Inc. v. Union Electric Co., 526 S.W.2d 310 (Me. Sup. Ct. 1975). 
510. See, e.g., Re Pacific Power \& Light Co., 69 P.U.R.3d 367 (Idaho Pub. Util. Comm'n 1967); In re Application of Mich. Consol. Gas Co. for Authorization of a Program for the Conservation of Natural Gas, 1 P.U.R. 4th 229 (Mich. Pub. Util. Comm'n 1973).

511. See, e.g., Nat'l Swimming Pool Inst. v. Kahn, 80 Misc.2d 655, 364 N.Y.S.2d 747, 9 P.U.R. 4th 237 (Sup. Ct. 1975); Leroy Fantasies, Inc. v. Swidler, 44 App. Div.2d 266, 354 N.Y.S.2d 182, 4 P.U.R.4th 334 (App. Div. 1974); Colo. Pub. Util. Comm'n, Decision No. 87640 (21 Oct 75).

512. Public Service Commission of New York v. FPC, 516 F.2d 746, 749, 10 P.U.R.4th 478, 480 (D.C. Cir. 1975).

513. The analysis of federal antitrust laws in this section draws heavily from Bezdek, supra note 15; at 365-67; Dean and Miller, supra note 15, at 336-37, N. Dean \& A. Miller, supra note 15, at 50072; Legal Barriers to Solar, supra note 15, at 9192. See also D. Zillman, "Solar Energy, Public Utilities, and the Competitive Economy," in The Solar Market: Proceedings of the Symposium on Competition in the Solar Energy Industry 214, 217-22 (June 1978) (presented at the 15-16 Dec 77 Solar Energy Symposium sponsored by the Bureau of Competition, United States Federal Trade Commission).

514. Service discrimination is given further treatment in the text accompanying notes 552-64 infra.

515. 15 U.S.C. \$\$ 1-7 (1976).

516. 410 U.S. 366 (1973).

517. Section two of the Sherman Act provides that:

Every person who shall monopolize, or attempt to monopolize, or combine or conspire with any other person or persons, to monopolize any part of the trade or commerce among the several States, or with foreign nations, shall be deemed guilty of a felony, and, on conviction thereof, shall be punished by fine not exceeding one million dollars if a corporation, or, if any other person, one hundred thousand dollars, or by imprisonment not exceeding three years, or by both said punishments, in the discretion of the court.

15 U.S.C. $\$ 2$ (1976).

518. 410 U.S. at $372-75$.

519. Id. at 377-79.

520. 428 U.S. 579 (1976).

521. 317 U.S. 341 (1943).

522. Cantor v. Detroit Edison Co., 392 F. Supp. 1110 (E.D. Mich. 1974), aff'd, 513 F.2d 630 (6th Cir. 1975) (affirmed without published opinion), rev'd, 428 U.S. 579 (1976).

523. 428 U.S. at 592-93. 
524. Id. at 598.

525. 98 S.Ct. $1123(1978)$.

526. City of Lafayette, Louisiana v. Louisiana Power \& Light Co., 532 F.2d 431 (5th Cir. 1976), aff'd, 98 S.Ct. 1123 (1978).

527. 98 S. Ct. at 1137 .

528. See Parker v. Brown, 317 U.S. 341 (1943).

529. 15 U.S.C. $\$ \$ 13,13 a, 13 b, 21 a(1976)$. The Act provides in part:

It shall be unlawful for any person engaged in commerce, in the course of such commerce, either directly or indirectly, to discriminate in price between different purchasers of commoditles of like grade and quality, where either or any of the purchasers involved in such discrimination are in commerce, where such commodities are sold for use, consumption, or resale within the United States... where the effect of such discrimination may be substantially to lessen competition or tend to create a monopoly in any line of commerce, or to injure, destroy, or prevent competition with any person who either grants or knowingly receives the benefit of such descrimination, or with customers of either of them: Provided, That nothing herein contained shall prevent differentials which make only due allowance for difference in the cost of manufacture, sale, or delivery resulting from the differing methods or quantities in which such commodities are to such purchasers sold or delivered ... And provided further, That nothing herein contained shall prevent persons engaged in selling goods, wares, or merchandise in commerce from soleoting their own customers in bona fide transactions and not in restraint of trade: And provided further, That nothing herein contained shall prevent price changes from time to time where in response to changing conditions affectlng the nuakket for or the marketability of the goods coneerned ... 15 U.S.C. $\$ 13$ (a) (1976).

530. U.S. Const. amend. XIV, § 1 .

531. See, e.g., Burton vo: Wilmington Parking Auth., 365 U.S. 715 (1961); Shelly v. Kraemer, 334 U.S. 1 (1948).

532. 419 U.S. 345 (1974).

533. 42 U.S.C. $\$ 1983$ (1976).

534. 419 U.S. at $354-55$.

535. Id. at 357 .

536. Id. at 351 .

537. Id. at 358. 
538. Id. at $358-59$.

539. 343 U.S. 451 (1952).

540. Id. at $454,458-59$.

541. Id. at 462 .

542. Id. It should be noted that while government action was found in the practice of broadcasting on the company's facilities, this practice was not in violation of the passengers first and fif th amendment rights. Id. at 463-66.

543. 409 F. Supp. 332 (N.D. Ga. 1975).

544. Id. at 338 .

545. 408, U.S. 564 (1972).

546. 409 F. Supp. at 338.

547. Id. at 341 .

548. 233 Ga. 558, 212 S.E.2d 628, 631 (1975).

549. Allied Chemical Corp. v. Georgia Power. Co., 236 Ga. 548, 224 S.E.2d 396, 399 (1976).

550. 4 Cal.3d 228, 481 P.2d 823, 93 Cal. Rptr. 455, 83 P.U.R.3d 494 (1971).

551. Id. at 294, 481 P.2d at 826, 93 Cal. Rptr. at 458, 88 P.U.R.3d at 498, citing, e.g., Rinaldi v. Yeager, 384 U.S. 305 (1966); Dandridge v. Williams, 397 U.S. 471 (1970).

552. E.g., United Fuel Gas Co. v. Railroad Comm'n, 278 U.S. 300, 309 (1929). For general discussions of a utility's service obligation, see Hodel \& Wendel, "The Duty and Responsibility of Oregon Public Agencies to Provide Adequate and Sufficient Electrical Utility Service," 54 Ore. L. Rev. 539-50 (1975); 1 A. Priest, supra note 21 , at 227-83.

553. 278 U.S. at 309; New York and Queens Gas Co. v. McCall, 245 U.S. 345, 351 (1917). In McCall, the Supreme Court held that: Corporations which devote their property to a public use may not pick and choose, serving only the portions of the territory covered by their franchises which it is presently profitable for them to serve and restricting the development of the remaining portions by leaving their inhabitants in discomfort without the service which they alone can render.

554. Id. See generally Muntguiner'y Ward \& Co. v Northern Pac. Terminal Co., 128 F. Supp. 475 (D. Ore. 1953); Vaught v. East Tennessee Tel. Co., 123 Tenn. 318, 13 S.W. 15 (1910). For examples and corresponding discussion of statutes establishing the duty to provide adequate service, see text accompanying notes 121-30 supra.

555. 1 A. Priest, supra note 21 , at 237-38.

556. See, e.g., Gary Heat, Light \& Water Co. v. Christ, P.U.R. 1921C 355 (Ind. Pub. Serv. Com m'n). 
557. E.g., Alabama Power Co. v. Dunlap, 240 Ala. 568, 200 So. 617 (1941); Bartman v. Wisconsin Mich. Power Co., 214 Wis. 608, 254 N.W. 376, 3 P.U.R. (n.S.) 144 (1934).

558. Re Superior Water, Light, \& Power Co., 78 P.U.R. (n.s.) 188 (Wis. Pub. Serv. Comm'n 1948).

559. See, e.g., City of High Point v. Duke Power Co., 34 F. Supp. 339 (M.D. N.C. 1940); Lew is v. Potomac Electric Power Co., 64 F.2d 701 (D.C. Cir. 1933). But see, e.g., City of Fort Collins v. Pub. Serv. Co. of Colo. 8 P.U.R. (n.s.) 361, 373-74 (Colo. Pub. Util. Comm'n 1935)(a factual distinction from the general rule is presented).

560. E.g., Re Union Elec. Co. of Mo., 90 P.U.R. (n.s.) 194 (Mo. Pub. Util. Comm'n 1950); Re Billings Gas Co., 26 P.U.R. (n.s.) 328 (Mont. Pub. Serv. Comm'n 1938).

561. See, e.g., Corporation Comm'n v. Southern Pac. Co., 55 Ariz. 173, 99 P.2d 702 $(1940)$.

562. See Bezdek, supra note 15, at 368; Dean and Miller, supra note 15, at 337-38; N. Dean and A. Miller, supra note 15, at 50073; Legal Barriers to Solar, supra note 15, at 83.

563. In New York, the use of gas was banned for heating swimming pools and in buildings without sufficient insulation. Nat'l. Swimming Pool Inst. v. Kahn, 80 Misc. 2d 655, 364 N.Y.S.2d 747, 9 P.U.R. 4th 237 (Sup. Ct. 1975); New York Pub. Serv. Comm'n. Case 26286 (Apr. 16, 1974). The use of gas has also been banned for decorative lighting. Leroy Fantasies, Inc. v. Swidler, 44 App. Div. 2d 266, 354 N.Y.S.2d 182, 4 P.U.R, 4th 334 (App. Div. 1974); Coln. Puh. IItil. Comm'n. Decision No. 87610 (Oct. 21, 1975).

564. E.g., Cal. Pub. Util. Code $\$ \S$ 2781-88 (West 1975). as amended, (West Supp. 1978); N.J. Stat. Ann. \$ 48:2-23 (Supp. 1978).

565. I. Selzer, supra note 96 , at 10 .

566. Id. at Table $\widetilde{\mathrm{D}}$ col. 5 .

567. E.g., California, Colorado, Massachusetts, Pennsylvania, and Rhode Island are studying the feasibility of rates for alternative energy users. See id. at D-1,4,8.

568. Interview with Richard Darwin, National Regulatory Research Institute (NRRI), Columbus, Ohio (24 July 78). Mr. Darwin indicated that NRRI was currently conducting an investigation for the federal government of existing solar rates.

569. Stelzer, supra note 96 , at $D-1$.

570. Id. at D-2.

571. Id. at D-3.

572. Id.

573. Id. at $\mathrm{D}-4$. 
574. Id. at $\mathrm{D}-5$.

575. Id. at D-6.

576. Id. at D-7.

577. Id. at D-8.

578. Orange and Rockland Utilities, Inc., Service Classification No. 7 (issued 7 Oct 77). The applicable charges are:

\begin{tabular}{|c|c|c|}
\hline & $\begin{array}{l}\text { Summer Months } \\
\text { (June-September) }\end{array}$ & $\begin{array}{l}\text { Other Months } \\
\text { (October-May) }\end{array}$ \\
\hline First $13 \mathrm{kWh}$ or less & $\$ 4.07$ & $\$ 4.07$ \\
\hline Next $47 \mathrm{kWh}$ & 0.0845 per $k W h$ & 0.0845 per $k W h$ \\
\hline Next $70 \mathrm{kWh}$ & 0.0739 per $k W h$ & 0.0739 per $k W h$ \\
\hline Next $370 \mathrm{kWh}$ & 0.0739 per $\mathrm{kWh}$ & 0.0651 per $k W h$ \\
\hline Next $500 \mathrm{kWh}$ & 0.0709 per $k W h$ & 0.0509 per $k W h$ \\
\hline Over $1,000 \mathrm{kWh}$ & 0.0709 per $\mathrm{kWh}$ & 0.0386 per $\mathrm{kWh}$ \\
\hline
\end{tabular}

The above charges were effective 1 June 78.

579. Orange and Rockland Utilities, Inc., Service Classification No. 1, Residential Service With Elec. Space and Water Heating (effective 1 June 78). The applicable charges are:

First $13 \mathrm{kWh}$ or less

Next $47 \mathrm{kWh}$

Next $70 \mathrm{kWh}$

Next $370 \mathrm{kWh}$

Next $500 \mathrm{kWh}$

Over $1,000 \mathrm{kWh}$

\begin{tabular}{l} 
Summer Months \\
(June-September) \\
\hline$\$ 4.07$ \\
0.0739 per $k W h$ \\
0.0739 per $\mathrm{kWh}$ \\
0.0739 per $\mathrm{kWh}$ \\
0.0509 per $\mathrm{kWh}$ \\
0.0709 per $\mathrm{kWh}$
\end{tabular}

Other Months

(October-May)

$\$ 4.07$

0.0845 per $\mathrm{kWh}$

0.0739 per $\mathrm{kWh}$

0.0651 per $\mathrm{kWh}$

0.0509 per $\mathrm{kWh}$

0.0386 per $k W h$

580. Orange and Rockland Utilities, Inc., Service Classification No. 1, General Residential Service (effective 1 June 78). The applicable charges are:

\begin{tabular}{|c|c|c|}
\hline & $\begin{array}{l}\text { Summer Months } \\
\text { (June-September) }\end{array}$ & $\begin{array}{l}\text { Other Months } \\
\text { (October-May) }\end{array}$ \\
\hline First $13 \mathrm{kWh}$ or less & $\$ 4.07$ & $\$ 4.07$ \\
\hline Next $47 \mathrm{kWh}$ & 0.0845 per $k W h$ & 0.0845 per $\mathrm{kWh}$ \\
\hline Next $70 \mathrm{kWh}$ & 0.0739 per $k W h$ & 0.0739 per $\mathrm{kWh}$ \\
\hline Next $370 \mathrm{kWh}$ & 0.0739 per $\mathrm{kWh}$ & 0.0739 per $\mathrm{kWh}$ \\
\hline Next $500 \mathrm{kWh}$ & 0.0709 per $\mathrm{kWh}$ & 0.0651 per $\mathrm{kWh}$ \\
\hline Over $1,000 \mathrm{kWh}$ & 0.0709 per $\mathrm{kWh}$ & 0.0621 per $\mathrm{kWh}$ \\
\hline
\end{tabular}

581. Orange and Rockland Utilities, Inc., Solar Assisted Service Rate, Case No. 27130 at 2 (N.Y. Pub. Serv. Comm'n, 12 Apr 77).

582. Id. at 4.

583. Interview with Joe Schuh, Rate Manager, Orange and Rockland Utilities, Inc., in Pearl River, N.Y. (9 Aug 78). 
584. Duke Power Co., General Service All-Electric/Solar, Schedule RAX (NC\&SC) (effective 1 Sept 78). The applicable charges are:

\begin{tabular}{lcc} 
Basic Facilities Charge & North Carolina & South Carolina \\
\cline { 2 - 3 } First $350 \mathrm{kWh}$ & $\$ 4.30$ & $\$ 4.30$ \\
Next $950 \mathrm{kWh}$ & 0.0288 per $\mathrm{kWh}$ & 0.0314 per $\mathrm{kWh}$ \\
Next $200 \mathrm{kWh}$ & 0.0348 per $\mathrm{kWh}$ & 0.0374 per $\mathrm{kWh}$ \\
All Over $1,500 \mathrm{kWh}$ & 0.0311 per $\mathrm{kWh}$ & 0.0337 per $\mathrm{kWh}$ \\
& 0.0259 per $\mathrm{kWh}$ & 0.0285 per $\mathrm{kWh}$
\end{tabular}

585. Duke Power Co., Residential Service All-Electric, Schedule RA (NC\&SC) (effective 1 Sept 78). The applicable charges are provided supra at note 584 .

586. Duke Power Co., General Residential Service, Schedule R (NC\&SC) (effective 1 Sept 78). 'The applicable charges are:

\begin{tabular}{lrr} 
& North Caroling & \multicolumn{1}{c}{ South Caroling } \\
Basic Facilities Charge & $\$ 4.30$ & $\frac{\$ 4.30}{20}$ \\
Firet $350 \mathrm{kWh}$ & 0.0288 per $\mathrm{kWh}$ & 0.0314 per $\mathrm{kWh}$ \\
Next $950 \mathrm{kWh}$ & 0.0444 per $\mathrm{kWh}$ & 0.0470 per $\mathrm{kWh}$ \\
Next $200 \mathrm{kWh}$ & 0.0420 per $\mathrm{kWh}$ & 0.0446 per $\mathrm{kWh}$ \\
All Over $1,500 \mathrm{kWh}$ & 0.0347 per $\mathrm{kWh}$ & 0.0373 per $\mathrm{kWh}$
\end{tabular}

587. Duke Power Co., Residential Service Water Heating - Electric/ Solar, Schedule RWX (NC\&SC) (effective 1 Sept 78). The applicable charges are:

\begin{tabular}{|c|c|c|}
\hline Basic Facilitie & $\frac{\text { North Carolina }}{\$ 4.30}$ & $\frac{\text { South Carolina }}{\$ 4.30}$ \\
\hline First $350 \mathrm{kWh}$ & 0.0288 per $k W h$ & 0.0314 per $\mathrm{kWh}$ \\
\hline Next $950 \mathrm{kWh}$ & 0.0318 per $k W h$ & 0.0375 per $\mathrm{kWh}$ \\
\hline All Over $1,300 \mathrm{kWh}$ & 0.0340 per $\mathrm{kWh}$ & 0.0366 per $\mathrm{kWh}$ \\
\hline
\end{tabular}

588. Duke Power Co., Residential Service Water Heating - Electric, Schedule RW (NC\&SC) (effective 1 Sept 78). The applícable charges are provided supl'd at rute 587.

589. Commonwealth Edison Co., Residential Service-Solar-Assisted Electric Space Heating, Rate 14E (effective 14 Oct 77). The applicable charges are:

Customer Charge

First $350 \mathrm{kWh}$

All Over $350 \mathrm{kWh}$

except that the net charge shall be $\$ 0.04194$ per $\mathrm{kWh}$ for all use over $350 \mathrm{kWh}$ per month in the Customer's first monthly billing period with an ending meter reading date on or after June 15 and in the three succeeding monthly billing periods.

Central minois Light Co., Residential Solar Assisted Electric Space Heating, Rate 4 (in effect Summer 1978). The applicable charges are:

Customer Charge

First $200 \mathrm{kWh}$

Next $200 \mathrm{kWh}$

All Over $400 \mathrm{kWh}$
$\$ 1.10$

0.05036 per $\mathrm{kWh}$

0.04658 per $\mathrm{kWh}$

0.02798 per $\mathrm{kWh}$ 
However, during the five consecutive billing months beginning with June of each year, all energy in excess of $400 \mathrm{kWh}$ shall be billed at $\$ 0.0535$ per $\mathrm{kWh}$.

590. Commonwealth Edison Co., Residential Service - Electric Space Heating, Rate 14 (in effect Summer 1978). The applicable charges are provided supra at note 589.

591. Commonwealth Edison Co., Residential Service, Rate 1 (in effect Summer 1978). The applicable charges are:
Customer Charge
$\$ 1.40$
All kWh
0.04194 per $\mathrm{kWh}$

592. Central Illinois Light Co., Residential Electric Space Heating, Rate 3 (in effect Summer 1978). The applicable charges are illustrated supra at note 589.

593. Central Illinois Light Co., Residential Service, Rate 1 (in effect Summer 1978). The applicable charges are:

\begin{tabular}{|c|c|c|}
\hline & $\begin{array}{c}\text { Summer } \\
\text { (June-October) }\end{array}$ & $\begin{array}{c}\text { Winter } \\
\text { (November-May) }\end{array}$ \\
\hline Customer Charge & $\$ 1.10$ & $\$ 1.10$ \\
\hline First $200 \mathrm{kWh}$ & 0.05036 per $\mathrm{kWh}$ & 0.05025 per $\mathrm{kWh}$ \\
\hline Next $200 \mathrm{kWh}$ & 0.05025 per $\mathrm{kWh}$ & 0.05025 per $\mathrm{kWh}$ \\
\hline All over $400 \mathrm{kWh}$ & 0.05350 per $\mathrm{kWh}$ & 0.05025 per $k W h$ \\
\hline
\end{tabular}

594. Utah Power \& Light Co., Residential Service-All-Electric With Solar-Assisted Hot Water Heating, Schedule No. 5A (tariff 19 effective 2 May 78). The applicable charges are:

Minimum Charge

First $60 \mathrm{kWh}$

Next $340 \mathrm{kWh}$

All Over $400 \mathrm{kWh}$
$\$ 3.25$

0.0756264 per $\mathrm{kWh}$

0.0356364 per $\mathrm{kWh}$

0.0251164 per $\mathrm{kWh}$

595. Utah Power \& Light Co., All-Electric Residential Service, Schedule No. 5 (tariff 19 effective 2 May 78). The applicable charges are provided supra at note 594 .

596. Utah Power \& Light Co., General Residential Service, Schedule No. 1 (tariff 19 effective 2 May 78). The applicable charges are:
Minimum Charge
$\$ 3.25$
First $60 \mathrm{kWh}$
Next $140 \mathrm{kWh}$
All Over $200 \mathrm{kWh}$
$\$ 0.0756264$ per $\mathrm{kWh}$
0.0578364 per $k W h$
0.0391064 per $\mathrm{kWh}$

597. Pub. Serv. Co. of N.H. with Total Envt $\eta$ Action, Inc., Special Contract-Electricity, Contract No. NHPUC-37 (21 Jan 77). Under this contract, auxiliary heating service is presently provided to a solar home utilizing a Megatherm electric hydronic thermal storage device during off-peak hours (10 p.m. -7 a.m.) at a rate of $\$ 0.024$ jper kWh.

598. Pub. Serv. Co. of N.H., Kesidential All-Electric Space Heating Service, Rate D (tariff 22 in effect Summer 1978). The applicable charges are: 
Customer Charge

First $500 \mathrm{kWh}$

All Over $500 \mathrm{kWh}$
$\$ 4.85$

0.0394 per $\mathrm{kWh}$

0.0315 per $\mathrm{kWh}$

599. Controlled water heating service is provided at an energy charge of $\$ 0.0195$ per kWh. Interview with Charles Stetson, Director of Rates and Load Research, Pub. Serv. Co. of N.H., in Manchester, N.H. (10 Aug 78).

600. Wis. Power \& Light Co., Supplemental Energy Off-Peak Service, Schedule R-2.1 (effective 10 Oct 77). The applicable charges are:

Fixed Charge

$\$ 3.50$ up to $50 \mathrm{k} W$ connected

$\$ 6.50$ over $50 \mathrm{~kW}$ and up to $75 \mathrm{~kW}$

eonncetod
Energy Charge

$\$ 0.071$ per $\mathrm{kWh}$ on-peak

n.n75 ner kWh nff-perk

\section{Pricing Periods}

On-peak period: 8 a.m. to 10 p.m., Monday through Saturday.

Off-peak period: 10 p.m. to 8 a.m., Monday through Saturday, plus all day Sunday.

601. Wis. Power \& Light Co., General Service, Schedule Rg-l (effective 10 Oct 77). The applicable charges are:

Customer Charge

First $100 \mathrm{kWh}$

Next $900 \mathrm{kWh}$

All Over $1,000 \mathrm{kWh}$
$\$ 2.50$

0.044 per $\mathrm{kWh}$

0.034 per $k W h$

0.0293 per $\mathrm{kWh}$

602. Kan. Gas and Elec. Co., Experimental Off-Peak Storage Rider, Schedule OPS 678 (effective June 1978). The applicable charge is $\$ 0.0201$ per $\mathrm{kWh}$ for all consumption.

603. Kan. Gas and Elec. Co., City Residential Total Electric Service, Schedule ORS 678 (effective June 1978). The applicable charges are:

\begin{tabular}{|c|c|c|}
\hline & $\begin{array}{c}\text { Summer } \\
\text { (June-October) }\end{array}$ & $\begin{array}{l}\text { Winter } \\
\text { (November-May) }\end{array}$ \\
\hline First $10 \mathrm{kWh}$ or less & $\$ 1.45$ & $\$ 1.45$ \\
\hline Next $90 \mathrm{kWh}$ & 0.05232 per $k W h$ & 0.05232 per $k W h$ \\
\hline Next $50 \mathrm{kWh}$ & 0.02366 per $k W h$ & 0.05232 per $\mathrm{kWh}$ \\
\hline Next $400 \mathrm{kWh}$ & 0.02085 per $k W h$ & 0.05232 per $k W h$ \\
\hline Next $600 \mathrm{kWh}$ & 0.02938 pel $k W h$ & 0.05232 per $\mathrm{kWh}$ \\
\hline All addt'l. kWh & 0.03452 per $k W h$ & 0.02085 per $k W h$ \\
\hline
\end{tabular}

604. Wis. Pub. Serv. Corp., Residential Space Cooling and Space Heating - Controlled (Special), Schedule Rc-Sl (effective 5 June 78). The applicable charges are:

Fixed Charge

$\begin{array}{cc}\begin{array}{c}\text { Summer } \\ \text { Energy Charge }\end{array} & \frac{\text { (July-October) }}{\$ 0.0210 \text { per kWh }}\end{array}$

$\$ 3.85$

Winter

(November-June)

$\$ 0.0200$ per $\mathrm{kWh}$

605. Wis. Pub. Serv. Corp., Urban Residential Service, Schedule Rg-1 (in effect Summer 1978). The applicable charges are: 
Fixed Charge

First $200 \mathrm{kWh}$

Next $1,300 \mathrm{kWh}$

All Over 1,500 kWh
Summer

(July-October)

$\$ 2.75$

0.0462 per $k W h$

0.0375 per $\mathrm{kWh}$

0.0375 per $k W h$
Winter

(November-June)

$\$ 2.75$

0.0435 per $\mathrm{kWh}$

0.0314 per $k W h$

0.0287 per $k W h$

606. Detroit Edison Co., Experimental Solar-Assisted Water Heating Service, D5.1 (in effect Summer 1978). The applicable charges are:

Service Charge

All $\mathrm{kWh}$

Interim Surcharge, All $\mathrm{kWh}$
$\$ 1.50$

0.0243 per $\mathrm{kWh}$

0.0096 per $\mathrm{kWh}$

607. Detroit Edison Co., Residential Electric Space Heating Service, D2 (in effect Sum mer 1978). The applicable charges are:

$\begin{array}{lcc} & \begin{array}{c}\text { Summer } \\ \text { (June-October) }\end{array} & \begin{array}{c}\text { Winter } \\ \text { (November-May) }\end{array} \\ \begin{array}{l}\text { Service Charge } \\ \text { Energy Charge }\end{array} & \\ \text { First 500 kWh Summer, } & & \\ \text { First 800 } & & \\ \text { kWh Winter } & 0.50 & \\ \text { Next 500 kWh Summer } & 0.0415 & 0.0385 \\ \text { All Over l,000 Summer, } & & \\ \text { All Over } & & \\ 800 \text { Winter } & 0.0445 & 0.0345\end{array}$

608. In Re Application of Detroit Edison Co. for Authority to Supply Electric Energy for Experimental Solar-Assisted Water Heating Service, Case No. U-5731 at 2 (Mich. Pub. Serv. Comm'n, 1 May 78).

609. Id. at 2-3.

610. Home Builders Ass'n of Metropolitan Denver v. Pub. Serv. Co. of Colo., Cases No. 5675,5685 , Decision No. 89573 (Colo. Pub. Util. Comm'n, 26 Oet 76).

611. Generic Hearings, Case No. 5693 (request for investigation as ordered in Decision No. 89068, Colo. Pub. Util. Comm'n, 13 July 76).

612. Testimony of James H. Ranniger, Manager of Rates and Regulations, Pub. Serv. Co. of Colo., Case No. 5693 at exhibit JHR-10 (filed 5 Aug 77).

613. Interview with Ronald Lehr, Attorney, Office of the Governor, Office of Energy Conservation, State of Colorado in Denver, Colorado (27 Sept 78).

614 . See supra at note 395.

615. The solar rate, as it would appear compared with the residential demand service rate effective 23 Aug 78 , is as follows:

Pub. Serv: Co. of Colo., Residential Solar Service, Schedule $\bar{R} \bar{D} S$. The applicable charges are: 
Demand Charge:

lst $\mathrm{kW}$ of Billing Demand or Less

$\mathrm{Al}$ over $1 \mathrm{~kW}$ of Billing Demand

Energy Charge:

All kWh

$\$ 5.90$

1.60 per $\mathrm{kW}$

.01001 per $\mathrm{kWh}$

616. Colorado Office of Energy Conservation Memorandum, Re Electric Utility Rates for Solar Uses 2-5 (6 Apr 78).

617. Id. at 5 .

618. Id. at 6.

619. Interview with Ronald Lehr, supra note 613.

620. L. Mayo et. al, Legal-Institutional Implication of Wind Energy Conversion Systems (WECS) 124 (September 1977) (prepared by the Program of Policy Studies in Science and Technology, George Washington University for the National Science Foundation, NSF Grant No. Apr-75-19137).

621. Unless noted otherwise, much of the following New York windmill experience is adopted from J. Carter \& Ted Finch, "Wind \& Solar at East 11th," Wind Power Digest, Summer 1977, at 12-17.

622. Consolidated Edison Co. of New York, Service Classification No. 2, General-Small (effective. 7 Mar 77; special provisions effective 23 May 77). The applicable charges are:

Energy Charge

First $10 \mathrm{kWh}$ or less

Noxt $880 \mathrm{kWh}$

$\$ 4.96$

All Over $900 \mathrm{kWh}$

0.0745 per $k W h$

Under special provision C, service to windmill generators operating in parallel with the company's system encompass additional charges and credits:
Minimum Charge (in addition to
$\$ 6.80$ per $\mathrm{kW}$ of
the $\$ 4.96$ above)
generator capacity
Reverse Flow Meter Charge
$\$ 1.00$

Credit for power generated by the windmill back into the comapny's system equal to the average cost of fuel per $\mathrm{kWh}$ to the company.

623. See Consolidated Edison Co. of N.Y., General Requirements for Parallel Operation of Windmill Generators with Low Tension Service (4 May 77) (Application and Design Manual No. 4).

624. Service Classification No. 2, supra note 622, at special provision C.4 (proposal of March 7, 1977).

625. Central Hudson Gas \& Elec. Corp., Service Classification No. 1 (effective 10 Aug 77; special provisions effective 10 Oct 77). The applicable charges are: 
Single Phase Service

First $12 \mathrm{kWh}$ or less

Next $60 \mathrm{kWh}$

Next $78 \mathrm{kWh}$

All Over $150 \mathrm{kWh}$

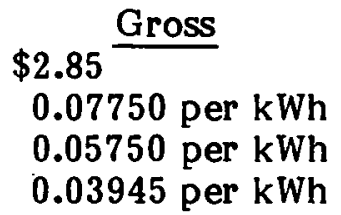

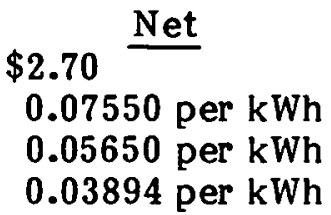

Under special provision 1.1 for windmill operation in parallel with the company's system, additional charges and credits are provided:
Demand Charge
$\$ 2.50$ per $\mathrm{kW}$ of
windmill capacity
Customer Meter Charge
$\$ 1.00$

For energy supplied by the customer to the company, there will be a credit equal to the company's average cost of fuel per $\mathrm{kWh}$.

626. Southern California Edison Co., Domestic-Parallel Generation, Experimental Schedule No. D-PG (1978). The applicable charges are:

Customer Charge

Net Energy Charge:

First $100 \mathrm{kWh}$

Next $200 \mathrm{kWh}$

All Over $300 \mathrm{kWh}$
$\$ 6.55$

No Charge

0.03562 per $\mathrm{kWh}$

0.02332 per $k W h$

Net energy is energy supplied by the Company minus energy generated by the customer and fed back into the Company's system at such time as customer generation exceeds customer requirements. Net energy cannot, however, have a negative value for purposes of determining charges under this schedule.

627. Southern California Edison Co., General Service-Parallel Generation, Experimental Schedule No. A-PG-A (1978). The applicable charges are:

Customer Charge (single phase

service)

$\$ 8.00$

Net Energy Charge:

First $100 \mathrm{kWh}$

Next $400 \mathrm{kWh}$

Next 1,000 kWh

Next $1,500 \mathrm{kWh}$

All Over $3,000 \mathrm{kWh}$

No Charge

0.06000 per $\mathrm{kWh}$

0.04150 per $\mathrm{kWh}$

0.03410 per $\mathrm{kWh}$

0.02679 per $\mathrm{kWh}$

628. Cal. Pub. Util. Code $\$ \S 2801-18$ (West Supp. 1978).

629. Id. at $\$ 2801$.

630 . Id. at $\$ 2802$.

631 . Id. at $\$ 2811$.

632. Id. at § 2812.5 . 
633. For a comprehensive summary of the five acts collectively referred to as the National Energy Act, see S. Glazer, Fact Sheet: National Energy Act (1978) (Prepared by the Environmental Study Conference); Office of Public Affairs, Department of Energy, Information: National Energy Act (1978).

In 1977, President Carter submitted to Congress a draft of proposed legislation to establish a comprehensive national energy policy. The President of the United States, National Energy Act: A Draft of Proposed Legislation to Establish a Comprehensive National Energy Policy, H.R. Doc. No. 95-138, 95 th Cong., 1st Sess. (1977). The President's proposal was comprehensive in nature and considered the five topics covered in the National Energy Act (NEA). Part E of the President's proposal, "Public Utility Regulatory Policies," was premised on a finding that the generation, transmission, and sale of electricity affect interstate commerce and that adequate and reliable supplies are necessary for both the general welfare and national security. Id. at $\$ 50 \mathrm{l}(\mathrm{a})$. The purposes of the electric utility ratemaking sections were (1) to establish national policies with respect to electric utility ratemaking which encourage economic efficiency, ensure that rates are designed to minimize energy consumption and to reduce the need for new generating capacity, and provide fair rates to consumers; and (2) to increase the efficiency of energy resource use in the generation and transmission of electric power through greater use of cogeneration, interconnection, and wheeling. Id. at $\$ 50 \mathrm{l}(\mathrm{b})$.

The House version of the NEA was passed by that body on August 5, 1977. H.R. 8444, 95 th Cong., 1st Sess. (1977). As did the President's proposal, the House version included the five broad areas with Part $V$ covering public utility regulatory policies. In addition to the purposes indicated in the President's proposal, the House version has as its purposes to provide for greater consumer representation in regulatory proceedings and to provide technical and financial assistance to state regulatory authorities. Id. at $\$ 501$.

The Senate proposal was composed of five separate bills with one devoted to public utility regulatory policies. H.K. 4018, 95th Cong., 1st Sess. (1977). In addition to the purposes provided in the earlier proposals, the senate version had as a purpose to provide an interim solution for the subsistence residential electrical needs of the elderly while Congress attempts to construct a rate structure equitable to all consumers. Id. at $\$ 102$. This version was passed by the Senate on 6 Oct 77 .

Because the House and Senate maintained different positions on public utility regulatory policies of the NEA, both chambers sent conferees to conference on H.R. 4018. Action was completed by the conference committe on December 1 , 1977, resulting in an unofficial Summary of Conference Agreement. Conference Committee, Summary of Conference Agreement on the Public Utility Regulatory Policies Act. H.R. 4018 (31 Dec 77) (unofficial). The ultimate result is the Public Utility Regulatory Policies Act of 1978 and other acts signed by President Carter late in 1978.

634. Public Utility Regulatory Policies Act of 1978, Pub. L. No. 95-617, 92 Stat. 3117 (1978).

635. Energy Tax Act of 1978, Pub. L. No. 95-618, 92 Stat. 3174 (1978).

636. National Energy Conservation Policy Act, Pub. L. No. 95-619, 92 Stat. 3206 (1978). 
637. Power Plant and Industrial Fuel Use Act of 1978, Pub. L. No. 95-620, 92 Stat. 3289 (1978).

638. National Gas Policy Act of 1978, Pub. L. No. 95-62 1, 92 Stat. 3350 (1978).

639. Pub. L. No. 95-617, 92 Stat. 3117 (1978). See also Conference Report: Public Utility Regulatory Policies Act of 1978, S. Rep. No. 95-1292, 95th Cong., 2d Sess. (1978).

640. Pub. L. No. 95-617, at $\$ 101$ (Title I - Retail Regulatory Policies for Electric Utilities).

641. S. Rep. No. 95-1292, at 69 .

642. Pub. L. No. 95-617, at $\$ 102$.

643. Id. at $\$ 111(\mathrm{a})$.

644. Id. at $\$ \$ 111(\mathrm{a}), 112$ (b). See also S. Rep. No. 95-1292, at 70.

645. Id.

646. Id. at 71 .

647. Public Utilities Regulatory Policy Act of 1977, H.R. 4018, 95th Cong., 1st Sess. $\$$ 107 (1977).

648. National Energy Act, H.R. 8444, 95 th Cong., lst Sess. $\$ 511$ (1977).

649. The President of the United States, National Energy Act: A Draft of Proposed Legislation to Establish a Comprehensive National Energy Policy, H.R, Doc. No. 95-130, 95th Cong., 13t Eess. 513 (1977).

650. Pub. L. No. 95-617, at $\$ 111(b)$.

651. Id. at \& $111(\mathrm{~d})$.

652. Id. at $\$ 111(d)(1)$.

653. Id. at $\$ 115(\mathrm{a})$.

654. Id. at $\$ 111(d)(2)$.

655. Id. at $\$ 111(\mathrm{~d})(3),(4)$.

656. Id. at $\S 115(\mathrm{~b})$.

657. Id. at $\$ 111(\mathrm{a})(5)$.

658. Id. at $\$ 111(\mathrm{~d})(6)$.

659. Id. at $\$ 115(\mathrm{c})$.

660. Id. at $\$ 113$. 
i

661 . Id. at $\$ 113(\mathrm{~b})$.

662. Id. at $\$ 114(a)$.

663. Id. at $\$ 114$ (b).

664. Id. at $\$ 121$.

665. Id. at $\$ 112(a)(1)$.

666. Id. at $\$ 122(a)(3)$.

667. Id. at $\$ 122(\mathrm{~b})$.

668. See 42 U.S.C. $\$ 6807$ (1976).

669. Pub. L. No. 95-617, at $\$ 141$.

670. Those standards potentially beneficial to solar users are discussed in the text accompanying notes $651-59,662-63$, supra.

67 1. Pub. L. No. 95-617, at \$\$ 201-14 (Title II -,Certain Federal Energy Regulatory Commission and Department of Energy Authorities).

672. See 16 U.S.C. $\$ 796$ (1976).

673. Pub. L. No. 95-617, at $\$ 201$.

674. S. Rep. No. 95-1292, at 89 .

675. Pub. L. No. 95-617, at $\$ 201$.

676. Id. at $\$ 210(a)$.

677. Id. at $\$ 210(\mathrm{~b}),(\mathrm{c})$. Regarding the purchase of electric energy by utilities from small power producers, "just and reasonable" is to be interpreted for the protection of electric consumers in receiving service at equitable rates. It is not intended that small power producers, by virtue of this common regulatory language, become subject to the tests traditionally administered to electric utility rate applications to ascertain what are just and reasonable rates. S. Rep. No. 95-1292, at 97.

For the sale of electric encrgy to small power producers by electric utilities, "just and reasonable" refers to traditional utility ratemaking concepts. Id. at 98. Thus, the rate would likely be based on the utility's cost to serve the small power producer.

678. Pub. L. No. 95-617, at $\$ 210$ (b).

679. Id. at $\$ 210$ (d).

680. Id. at $\$ 210(e)(1)$.

681. Id. at $\$ 210(\mathrm{e})(2)$. 


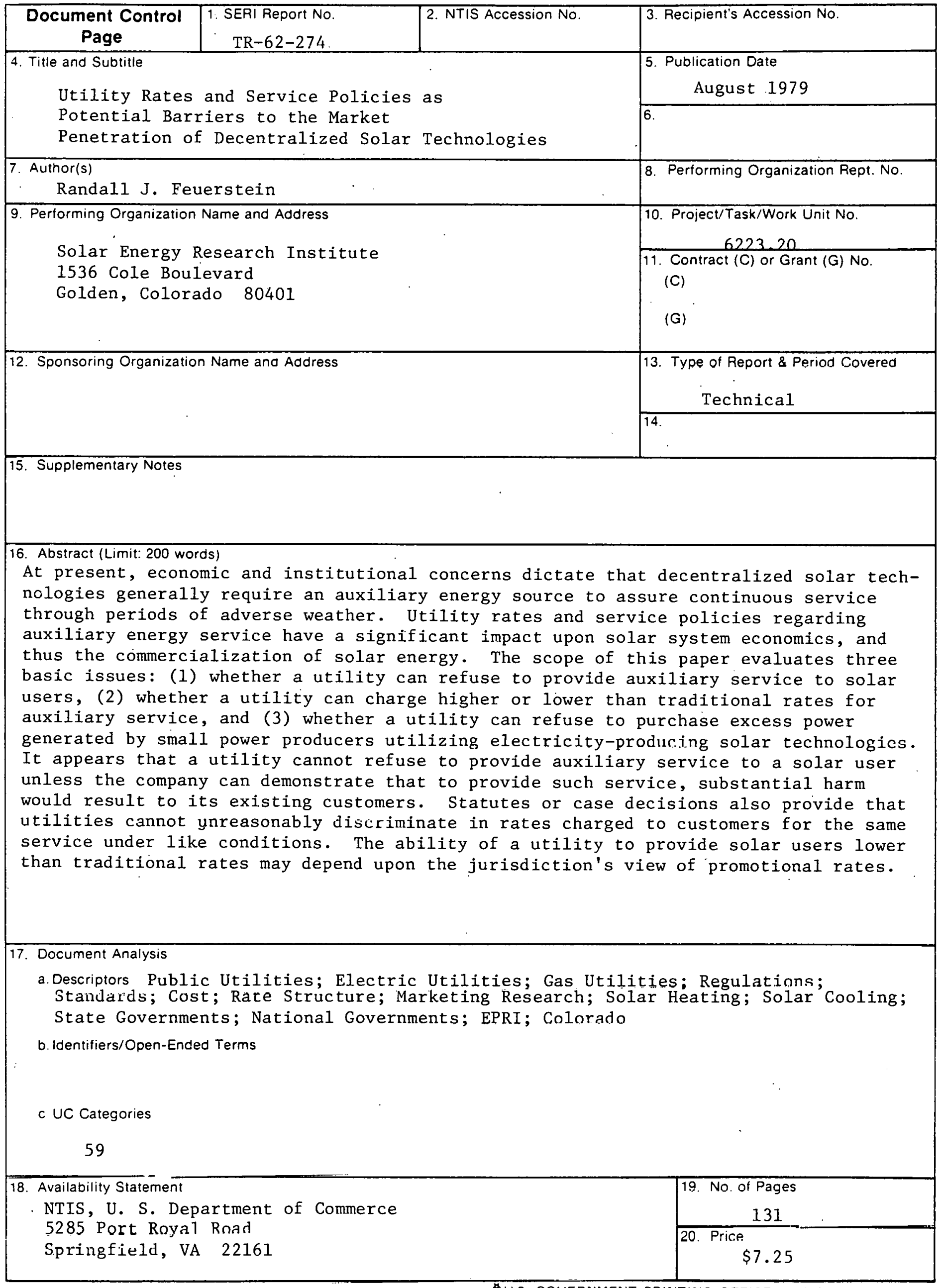

